\title{
The Role of Media Channels in Strenghtening National Values From the View of Parliamentarians of Kurdistan
}

\author{
Majid Salih
}

\begin{abstract}
National belonging is one of the important discussions that sociologists have worked on it for more than two centuries. Most of experts of nationalism think that national identity has five main dimensions that each of them is affected by a number of interior and exterior factors. These factors are political, historical, social, cultural, and geographical .

After development of communication technology and affecting this technology on media channels, the impact of different kinds of media on weakening or strengthening of national belonging is increasing. In the present research it is aimed to explore the impact of Kurdish media channels on weakening or strengthening of national belonging. In addition, through a questionnaire given to Kurdistan.
\end{abstract}




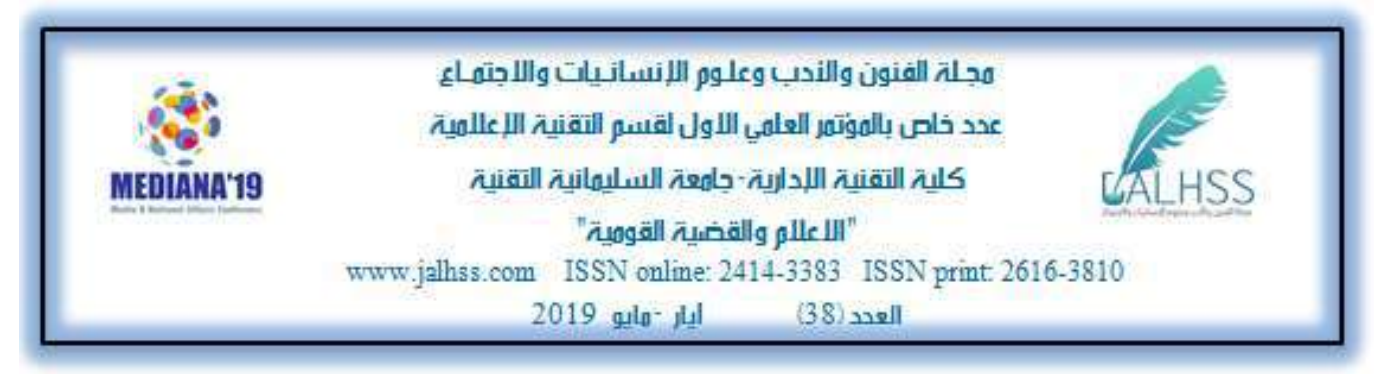

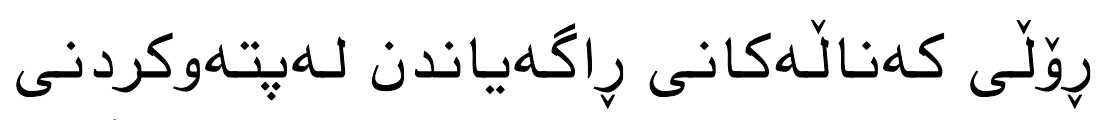

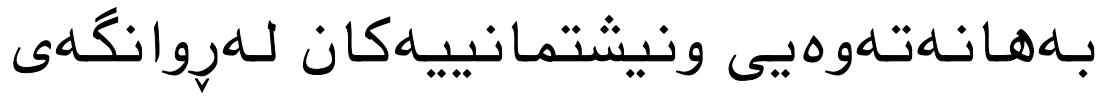

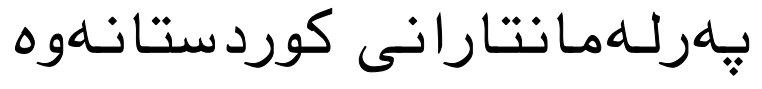

\author{
م·ى. ملهجيد سالح
}

\begin{abstract}
بيوخته

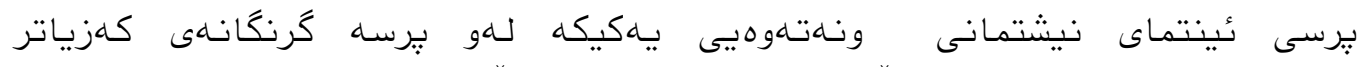

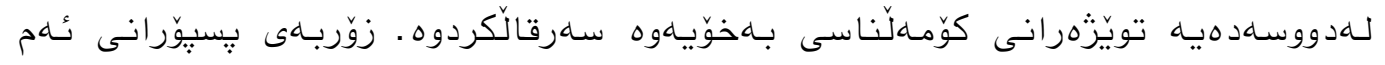

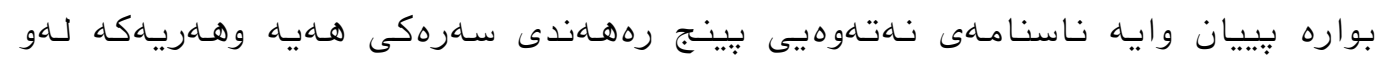

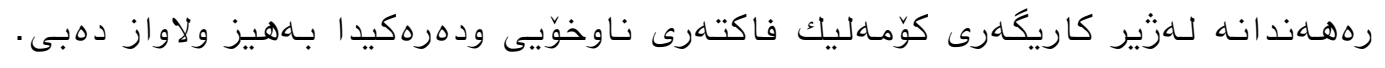

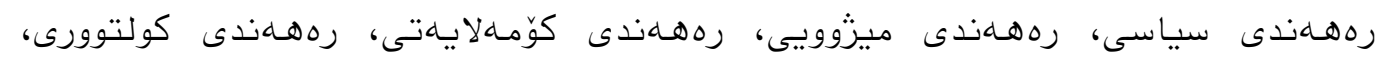

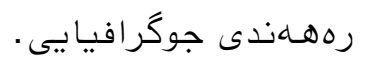

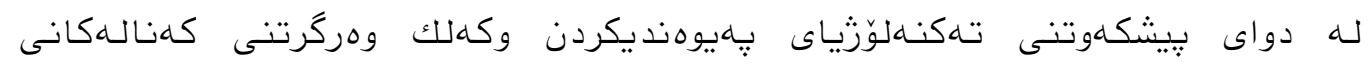

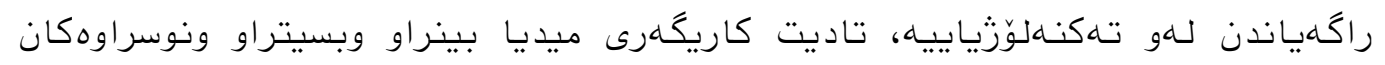

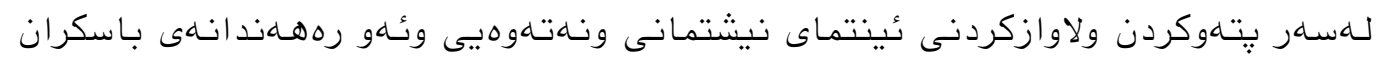

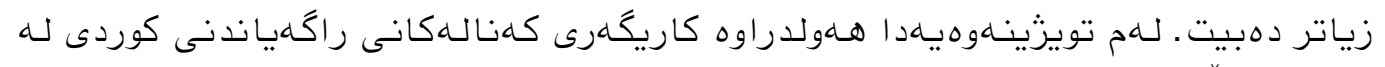

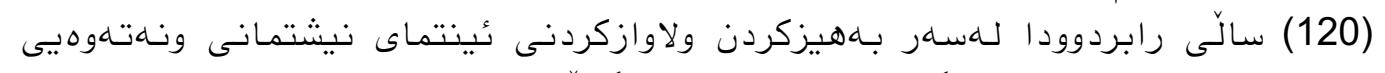

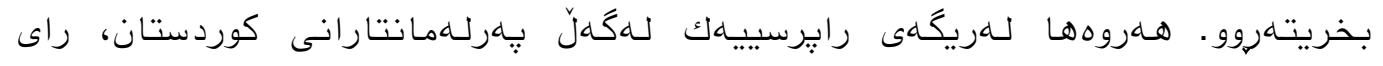

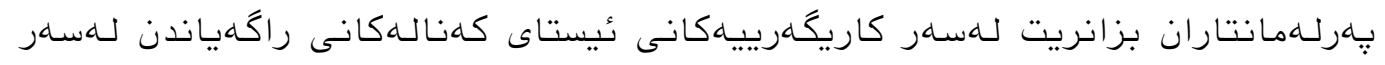

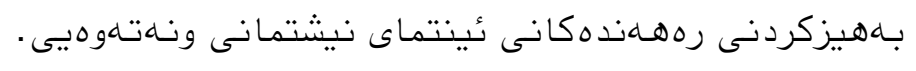



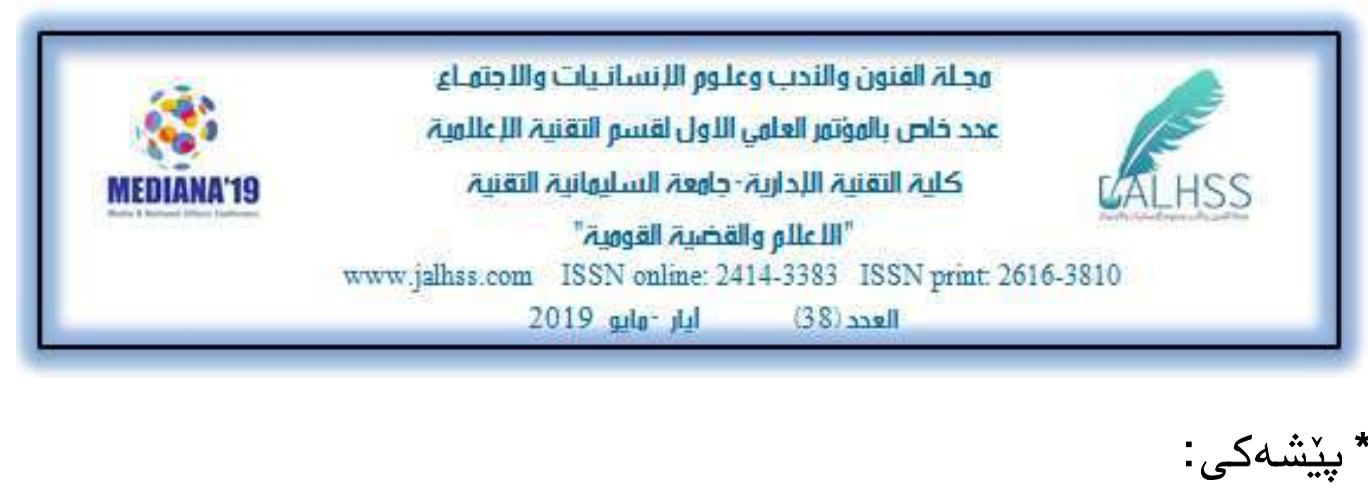

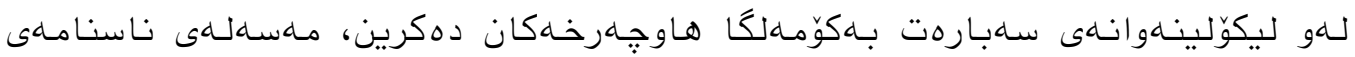

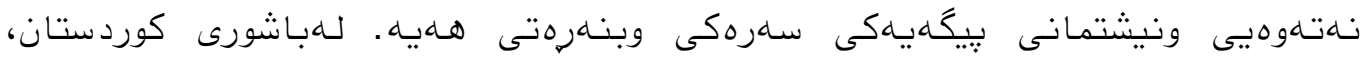

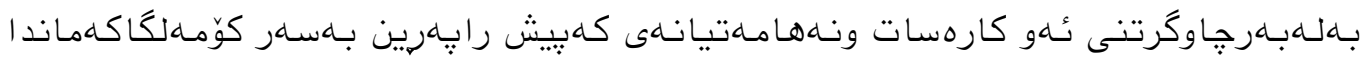

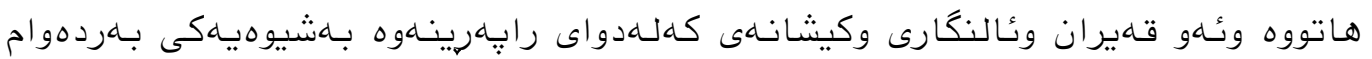

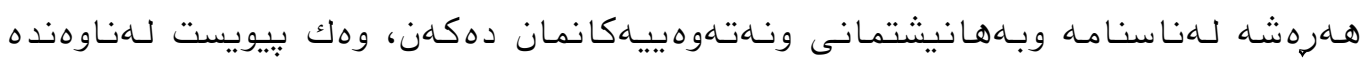

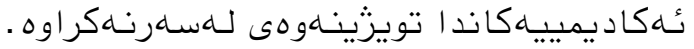

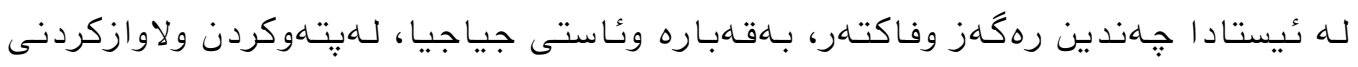

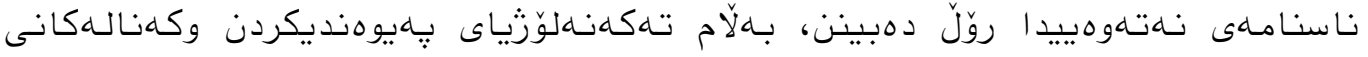

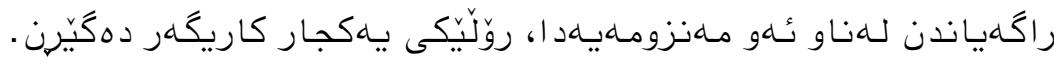

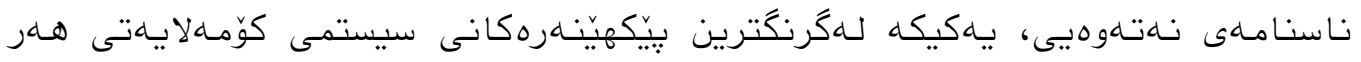

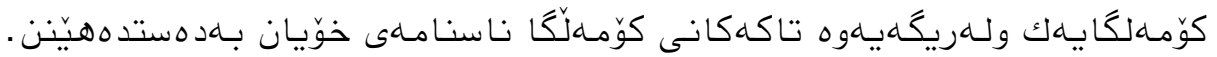

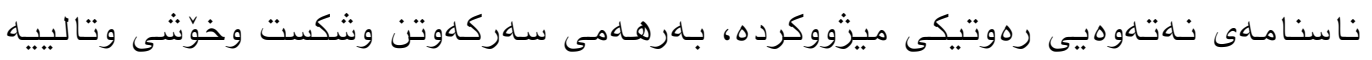

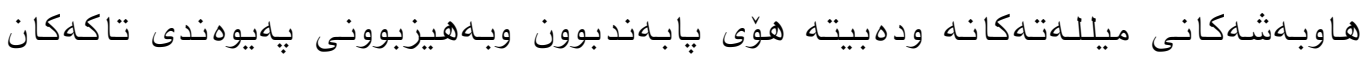

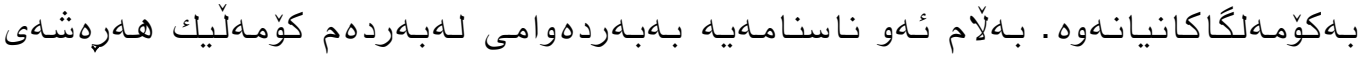

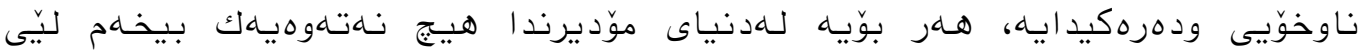

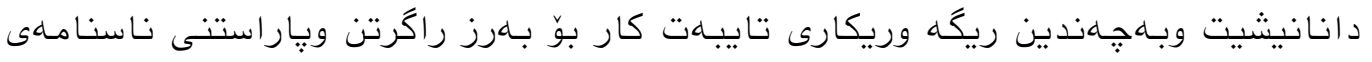

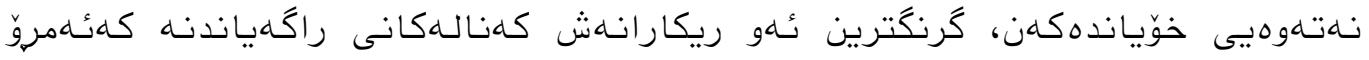

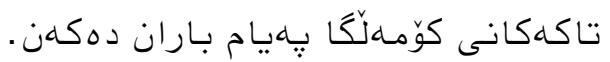

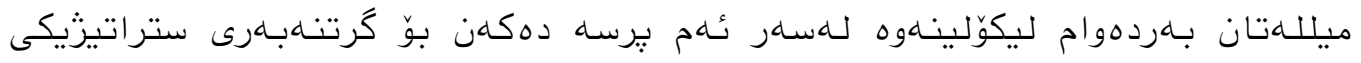

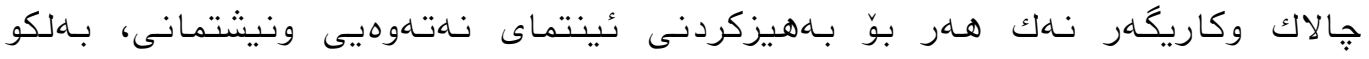

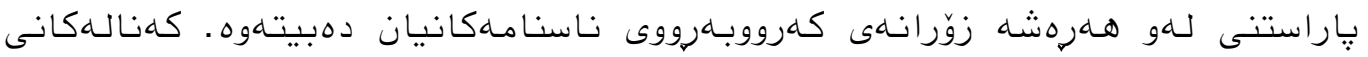

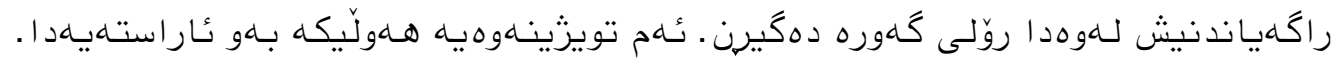
- كليلى زاراوهكان: كهنالهكانى راكَهياندن، بـهـانهتهوهييهكان، پهرلـهمانتاران. 


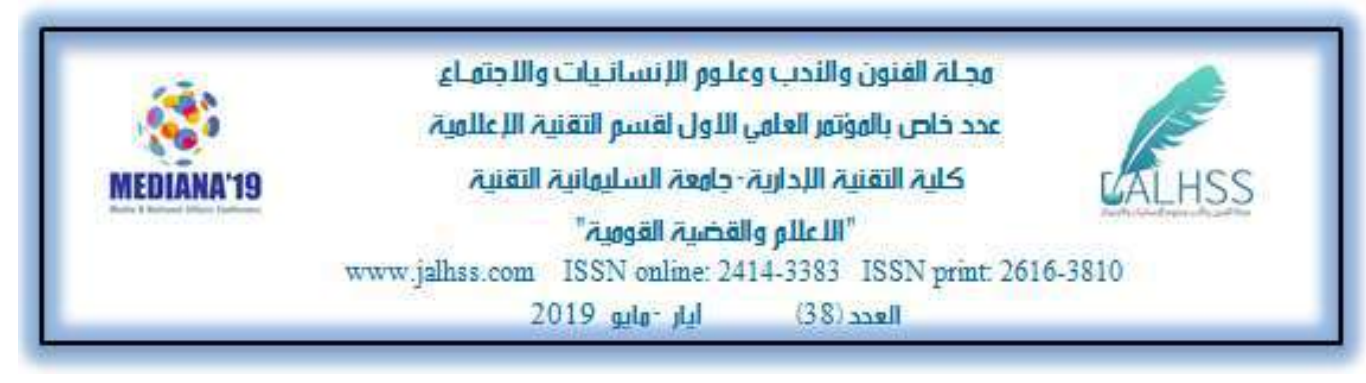

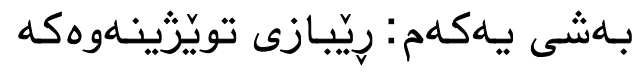

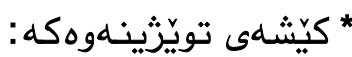

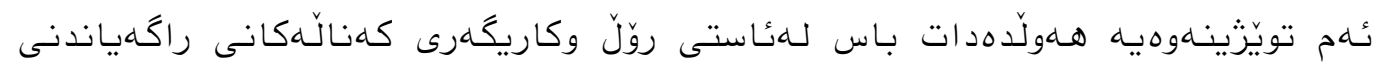

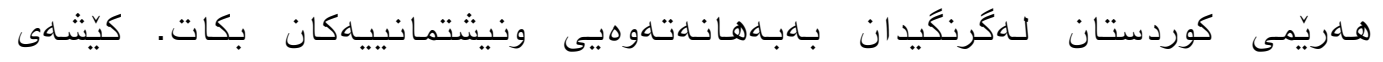

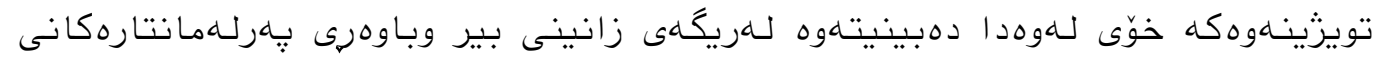

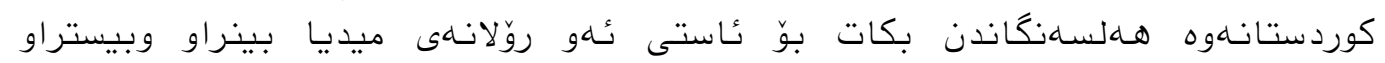

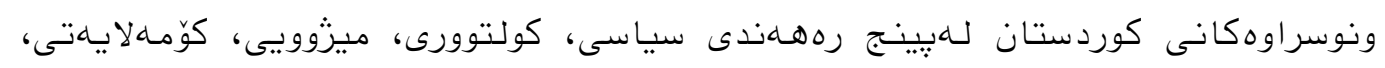

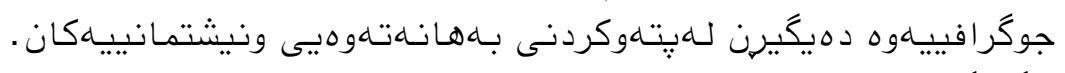

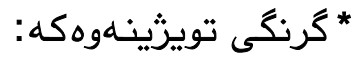

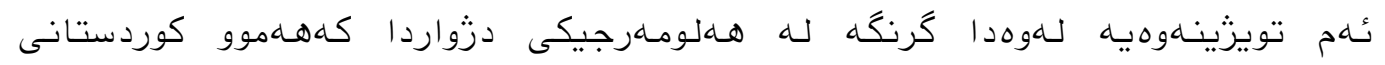

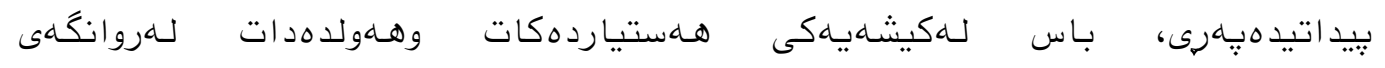

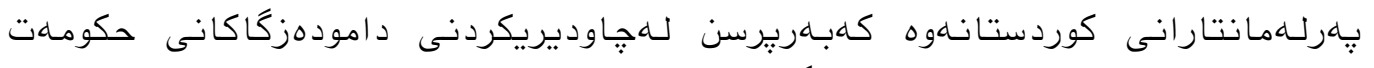

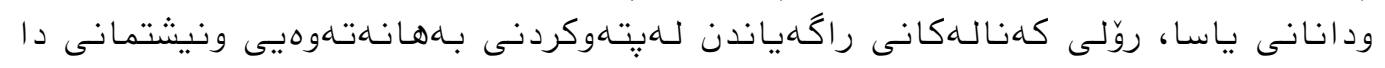
دربخات.

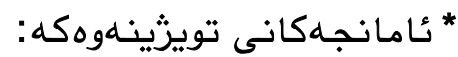

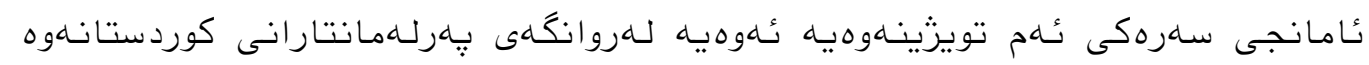

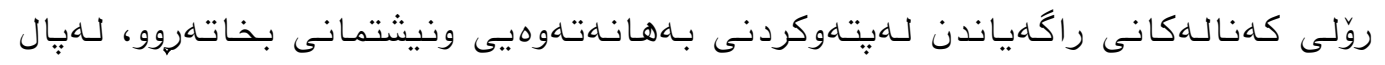

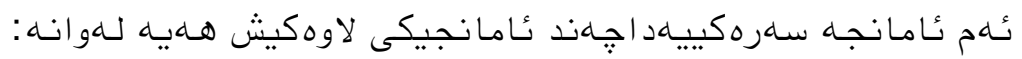

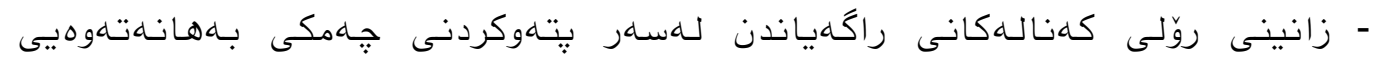

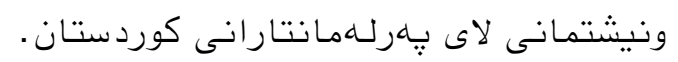

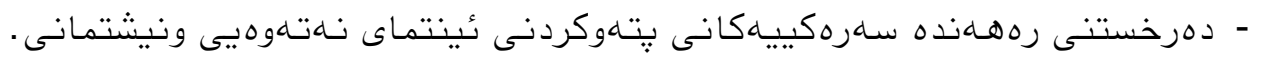

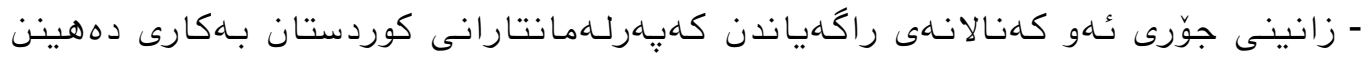

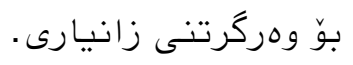

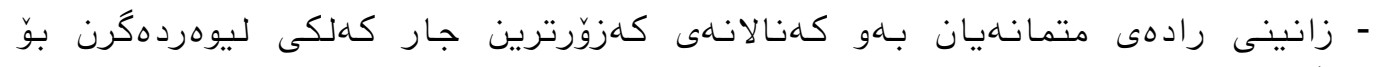

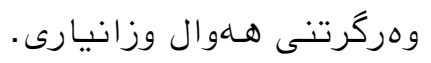

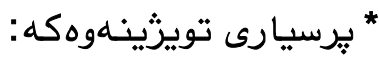

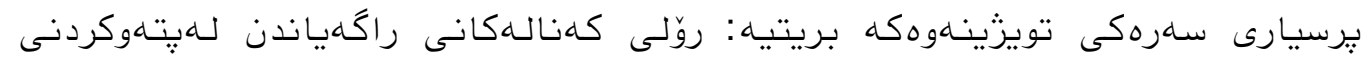

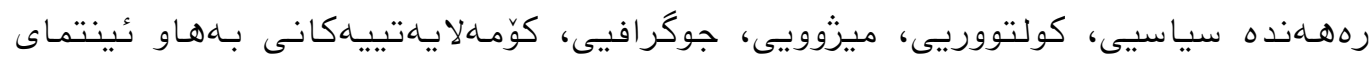

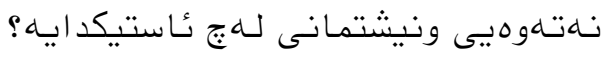




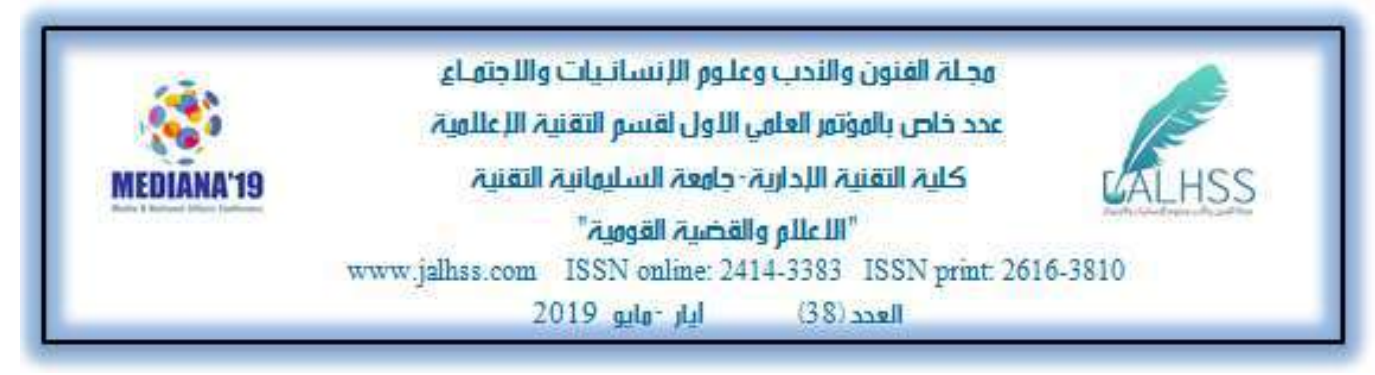

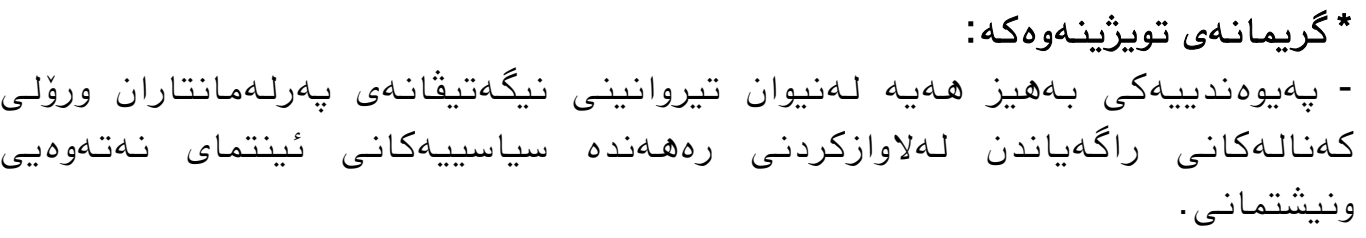

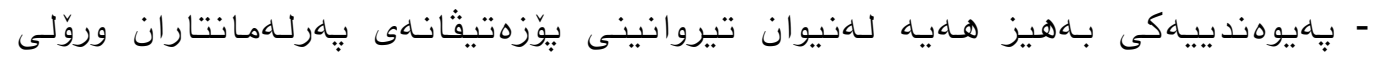

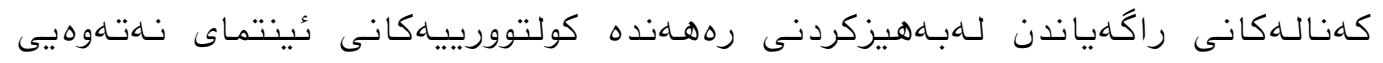
ونيشتمانى .

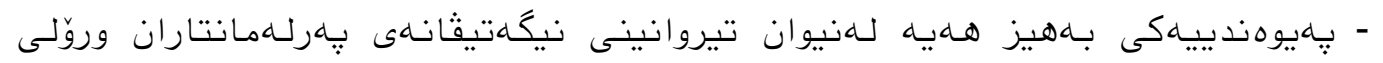

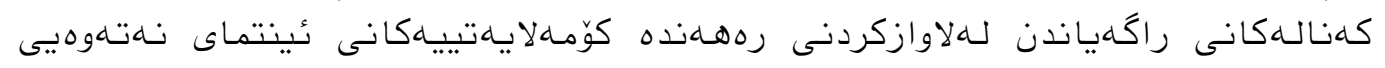
ونيشتمانى - ونسان

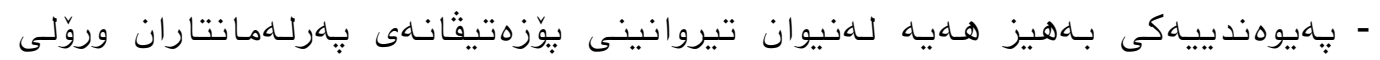

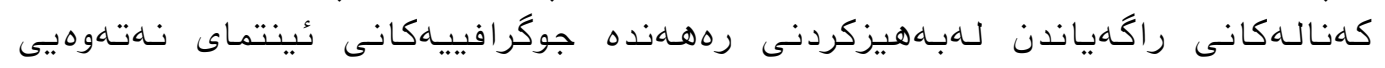
ونيشتمانى

\section{بـهـى دووهم: جِوارجيوهى تيوّرى تويزينهلوهكه}

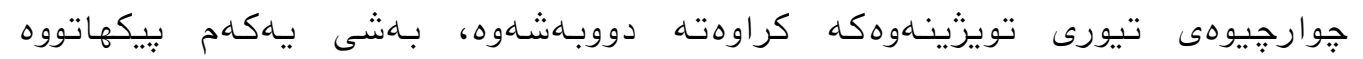

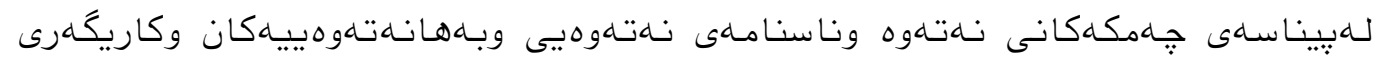

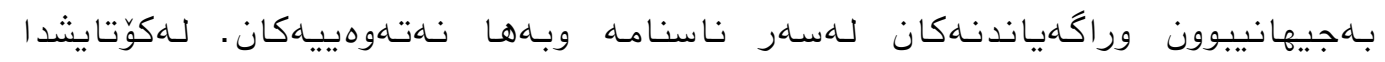

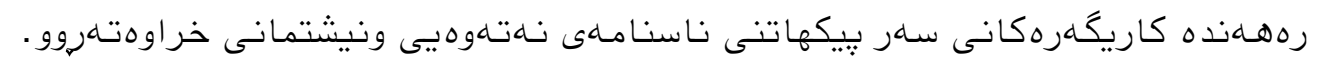

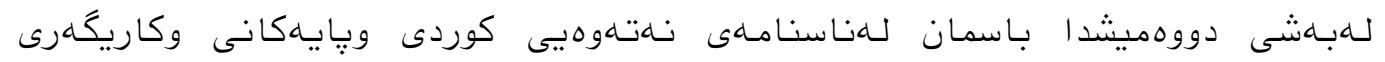

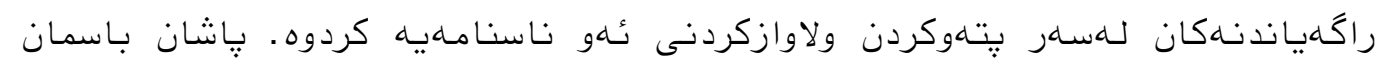

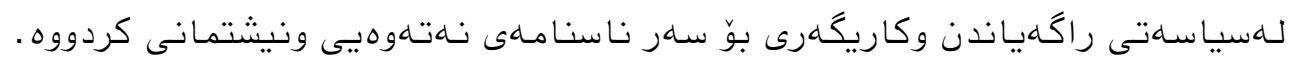

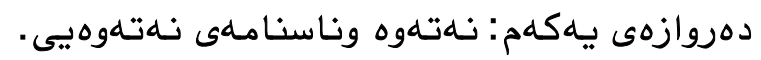

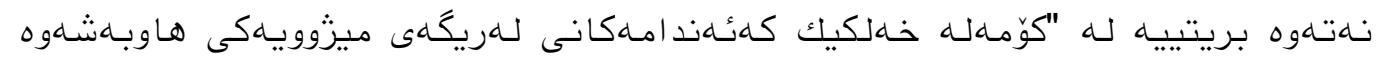

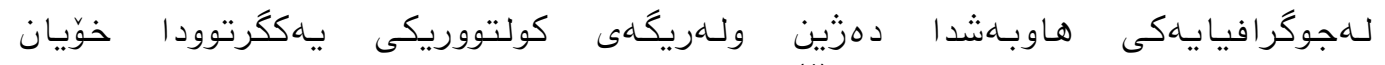

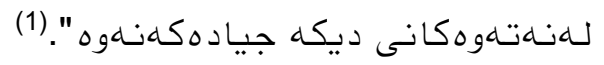

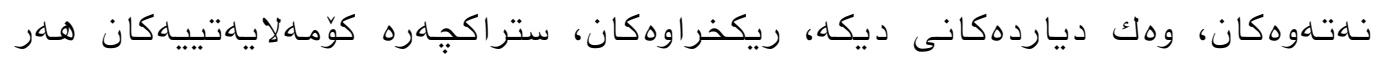

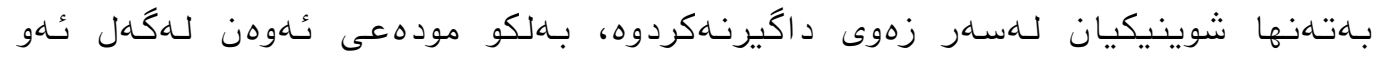

1 .Thompson, Andrew (2001); "National Identity and Human Agency", The sociological Review, Vol. 49, No. 1, PP 18-32 


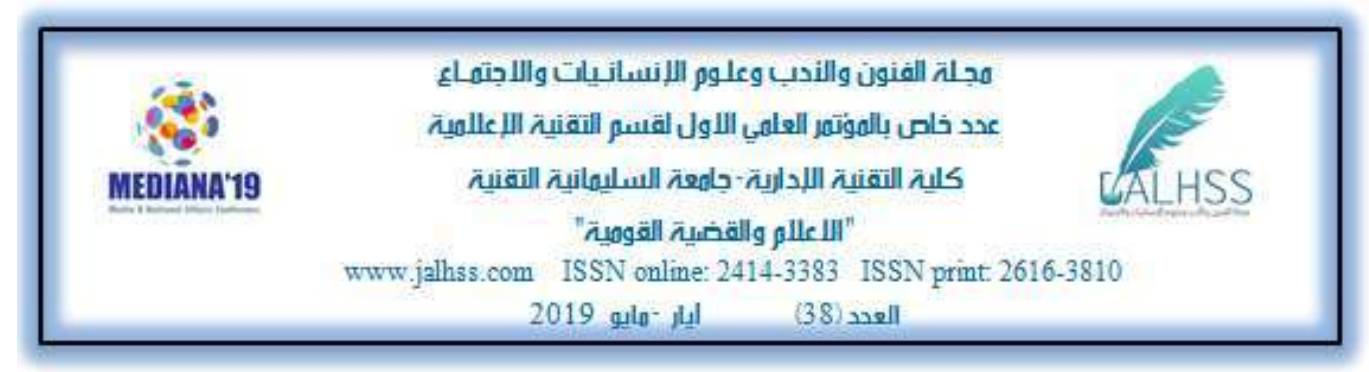

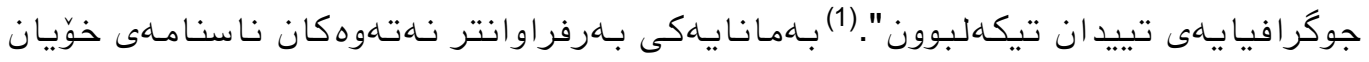

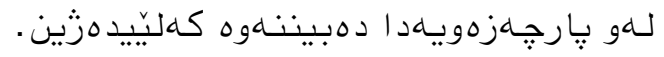

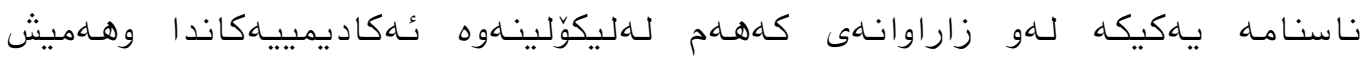

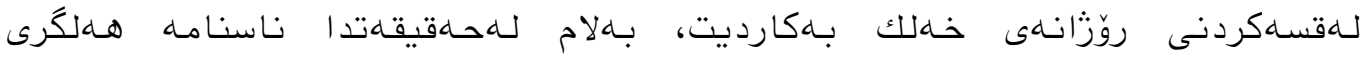

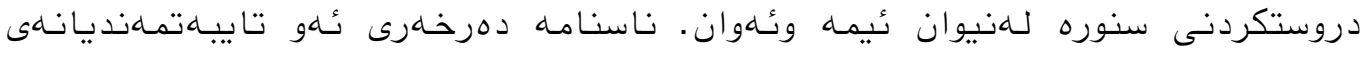

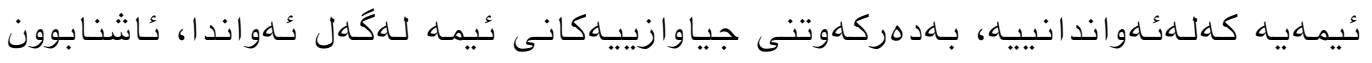

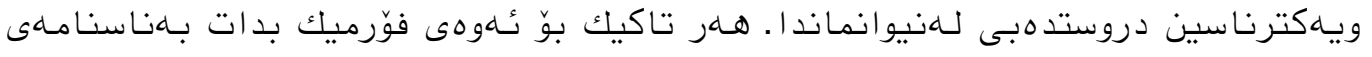

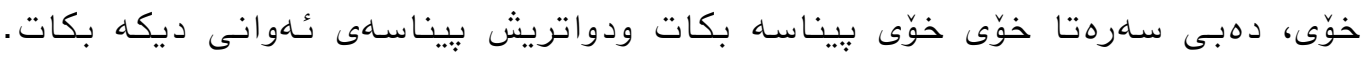

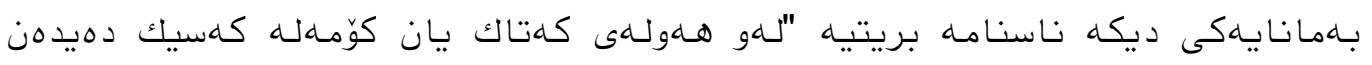

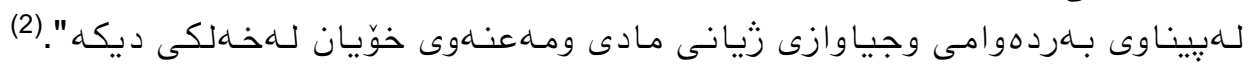

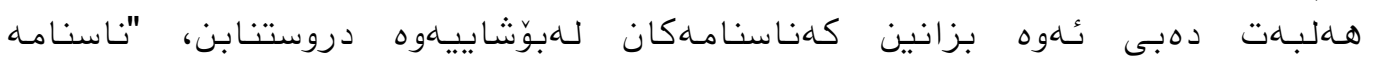

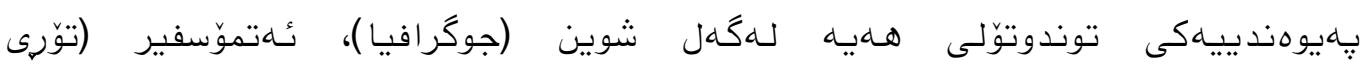

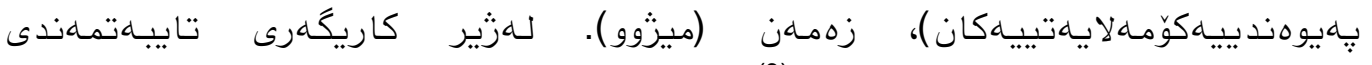

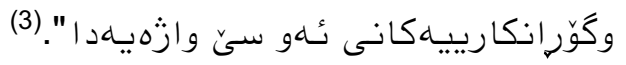

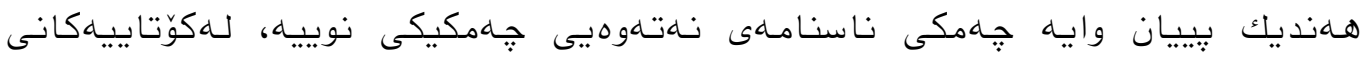

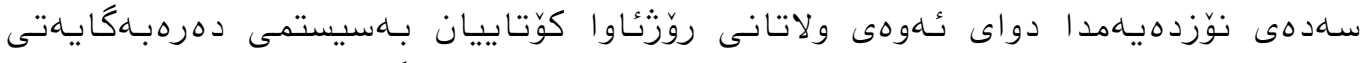

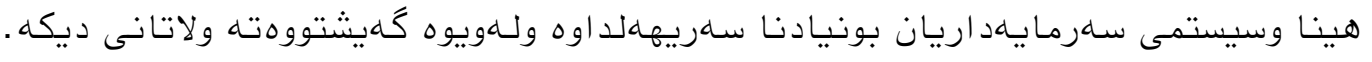

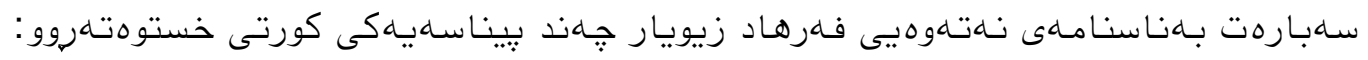

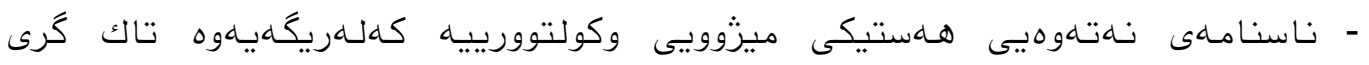

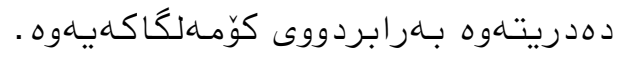

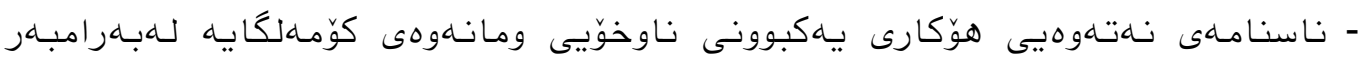

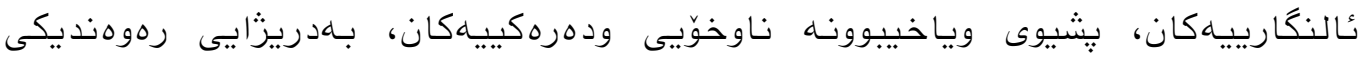
ميزوويى دريزخايسهن

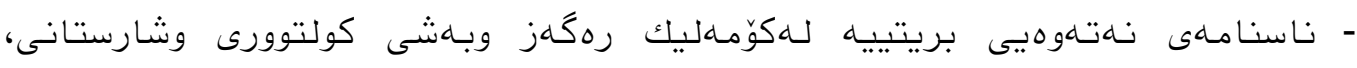

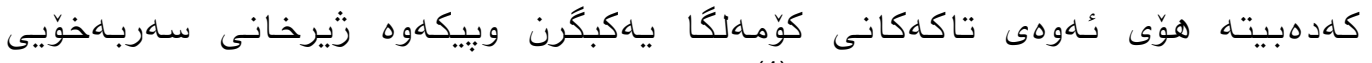

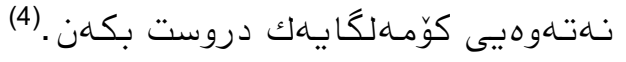

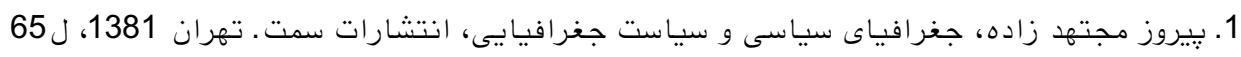

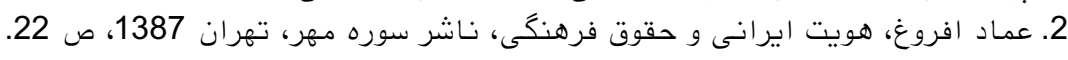

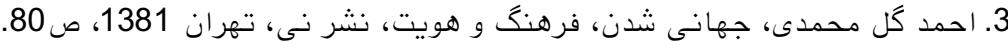

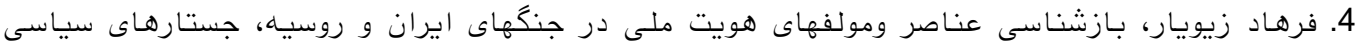

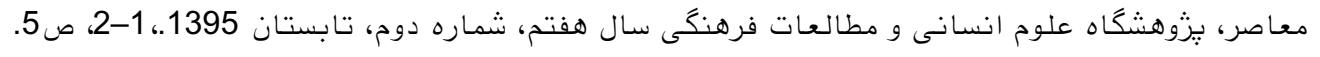




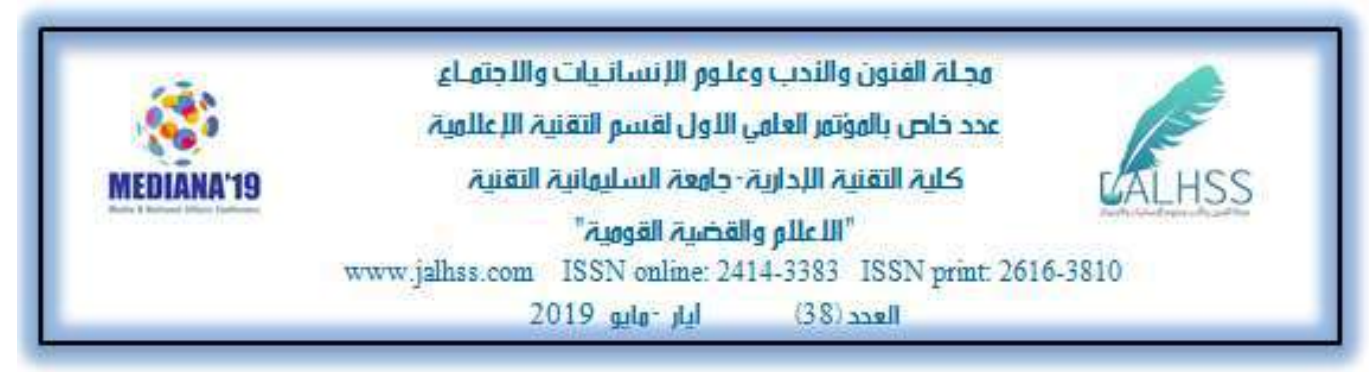

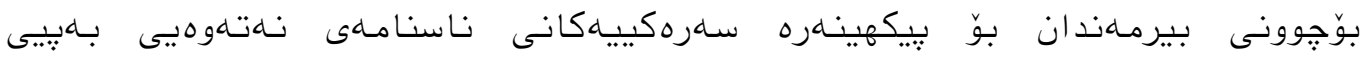

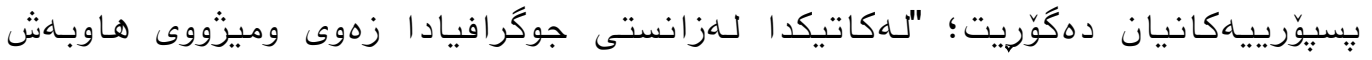

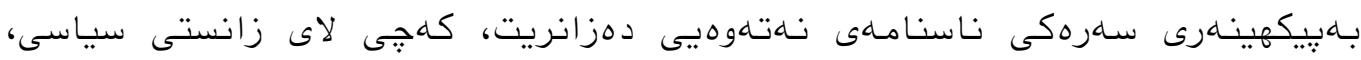

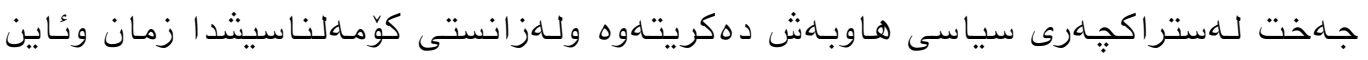

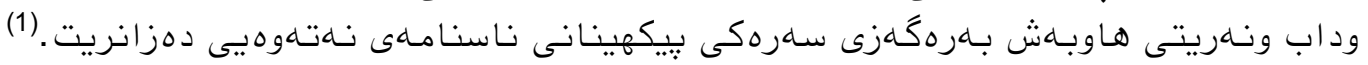

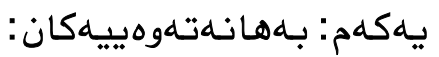

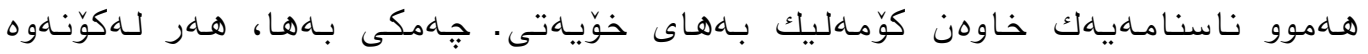

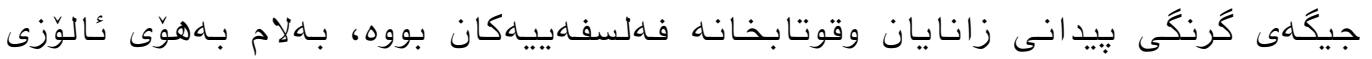

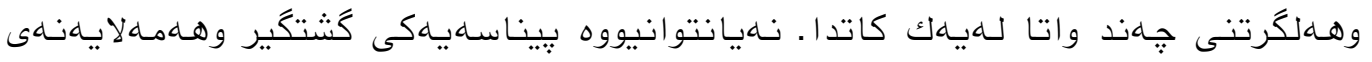

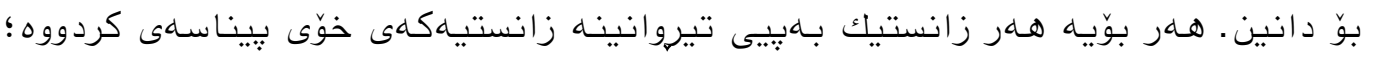

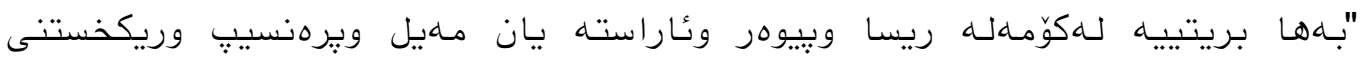

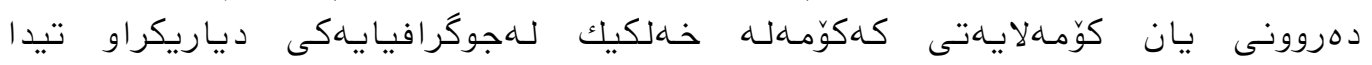

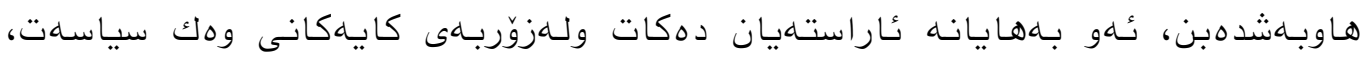

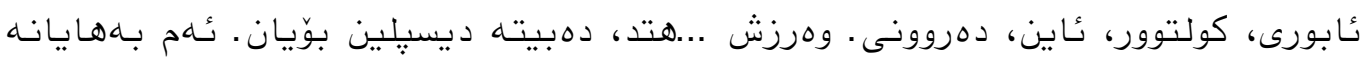

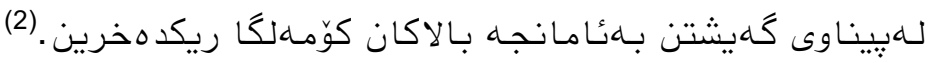

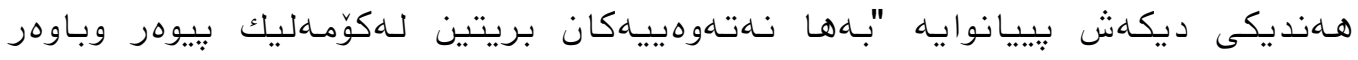

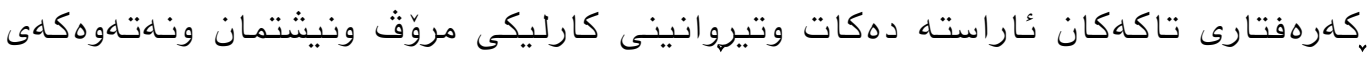

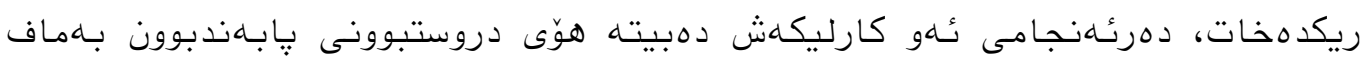

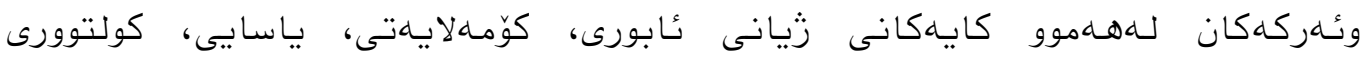

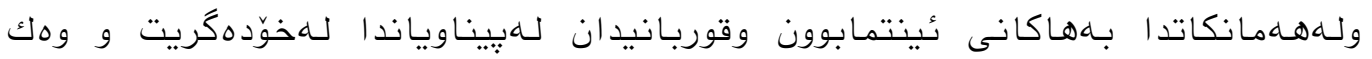

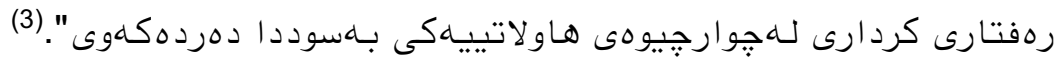

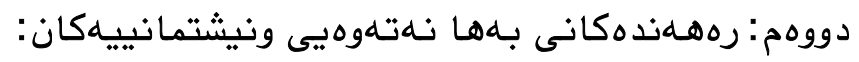

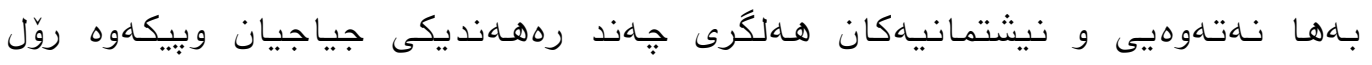

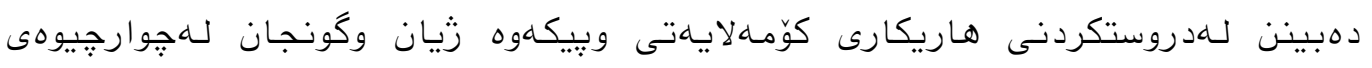

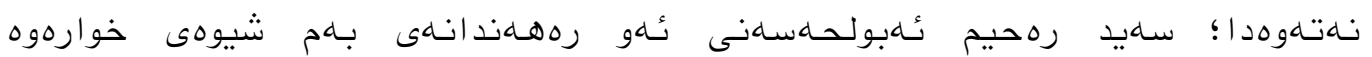

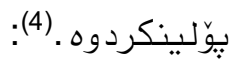

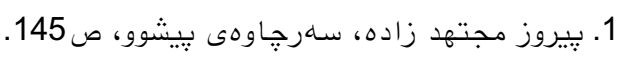

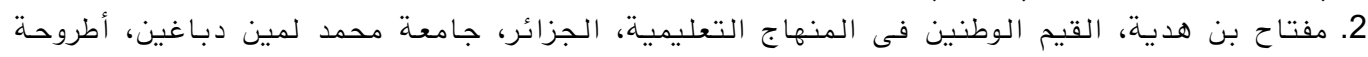

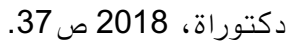

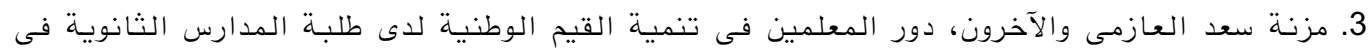

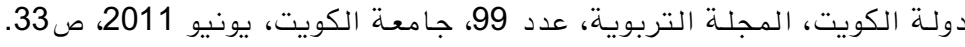

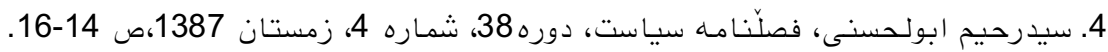




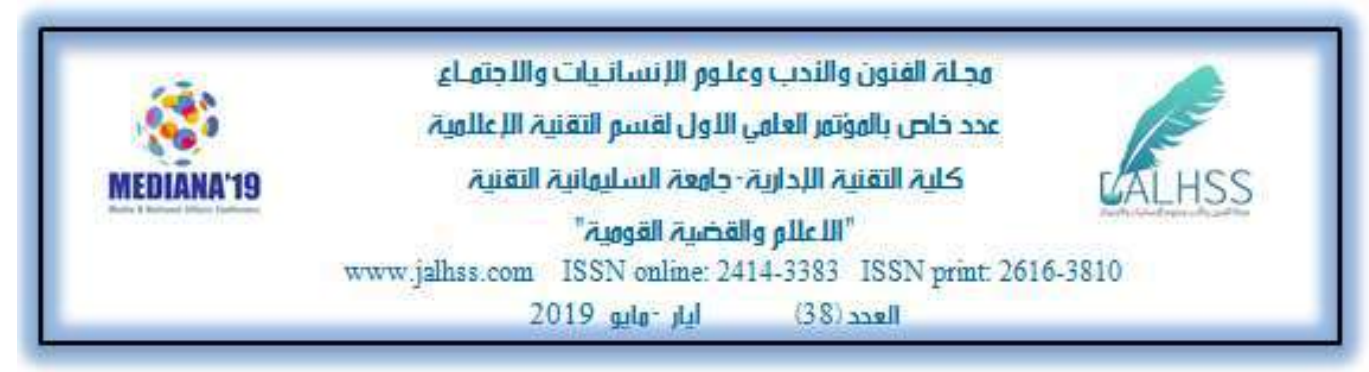

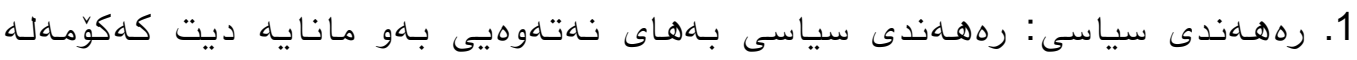

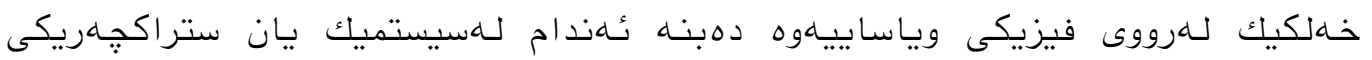

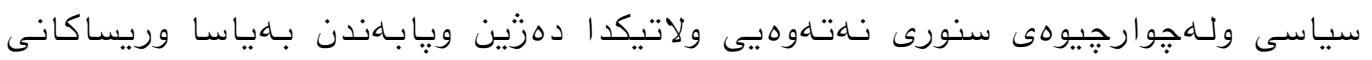

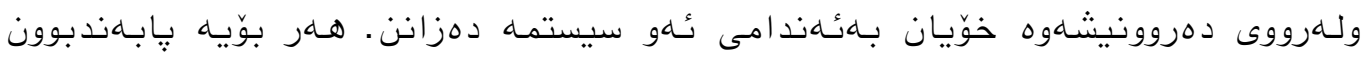

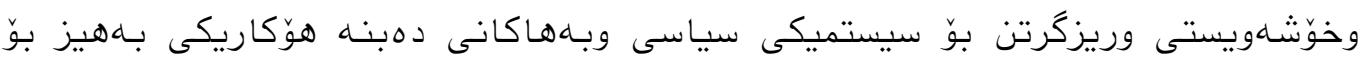

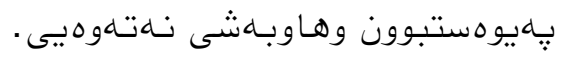

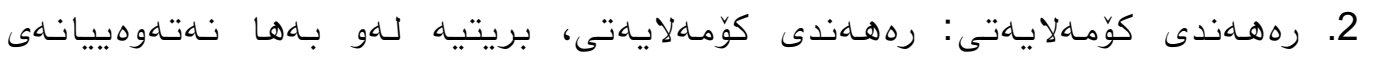

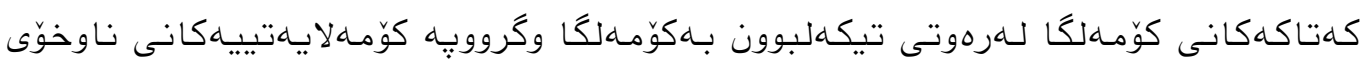

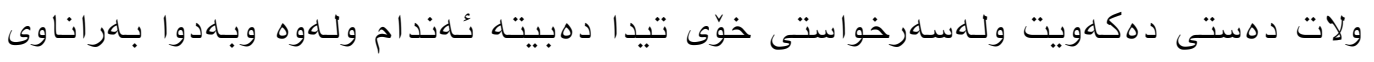

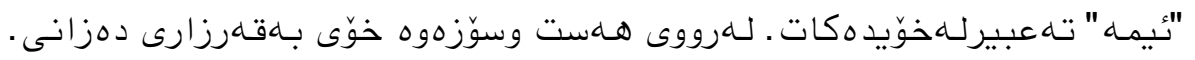

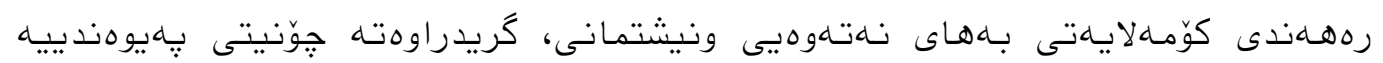

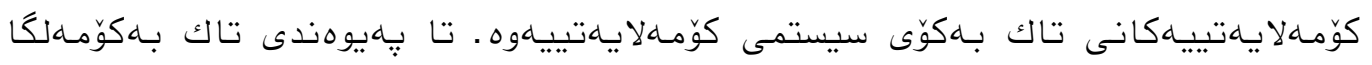

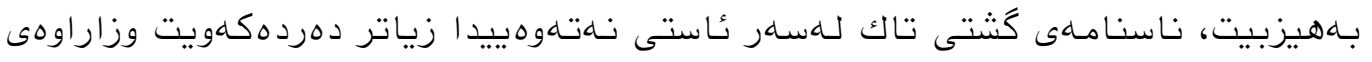

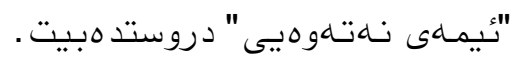

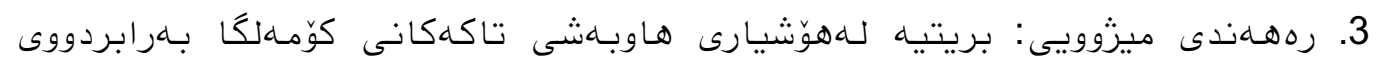

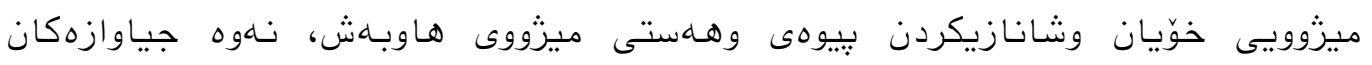

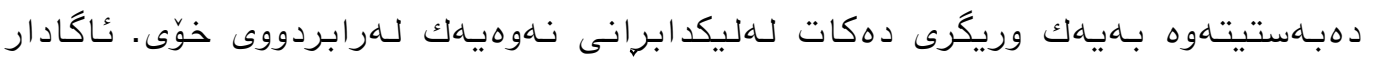

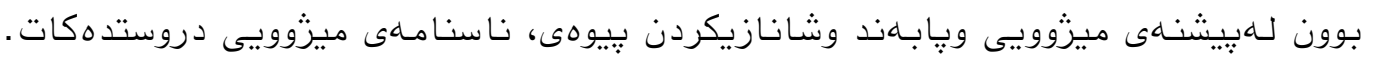

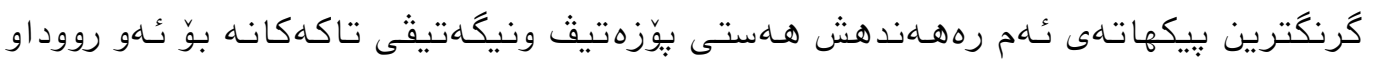

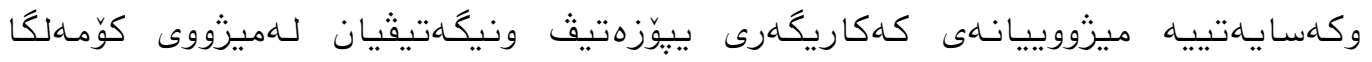

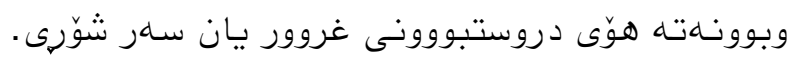

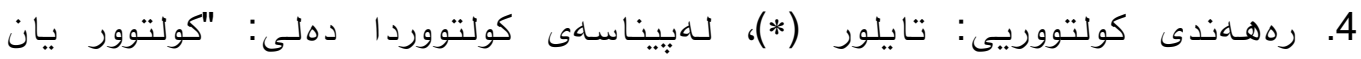

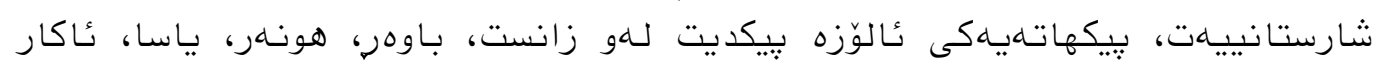

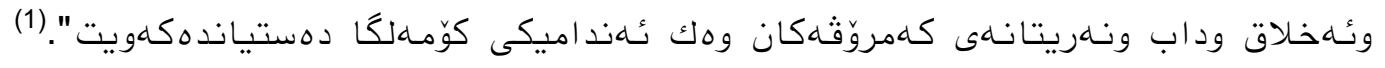

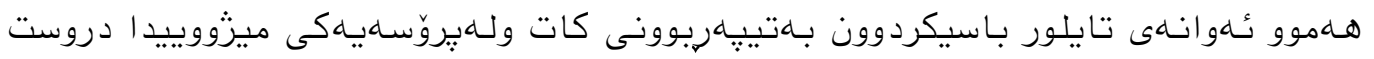

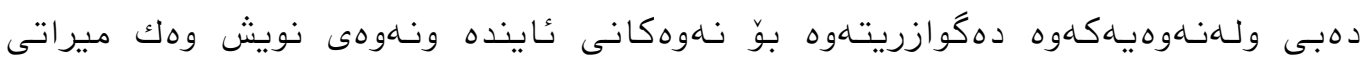

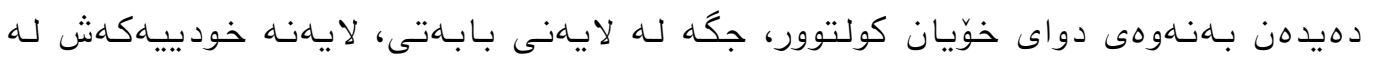

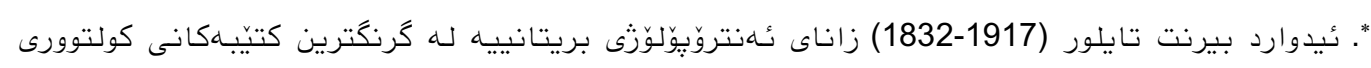
سارهتاييه. 1. جين اريك لين، سوانته ارسون، فرهنگ و سياست، بزُوهشكده مطالعات فرهنگى و اجتماعى، تهران، 1392، ص.44 اريك لين 


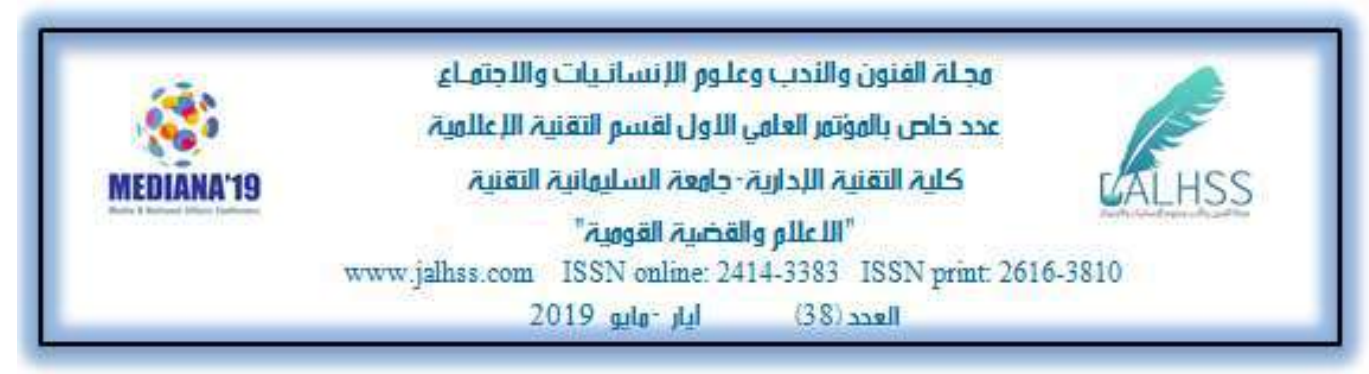

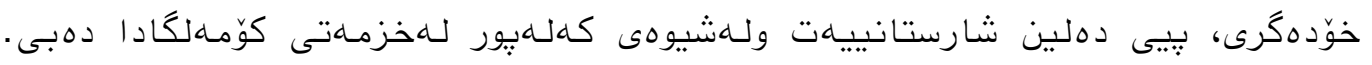

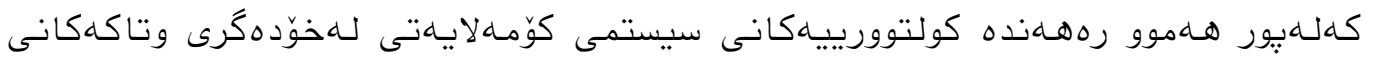

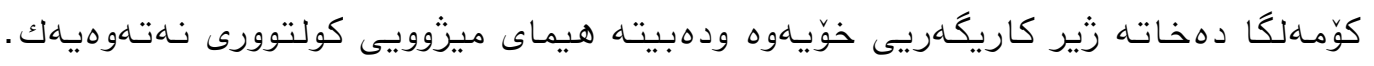

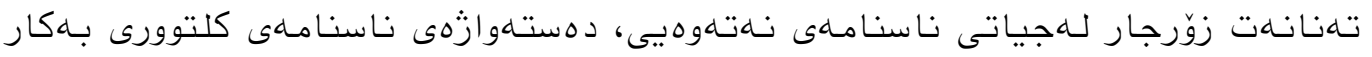

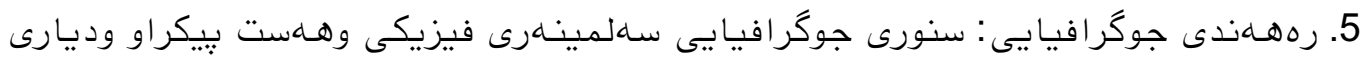

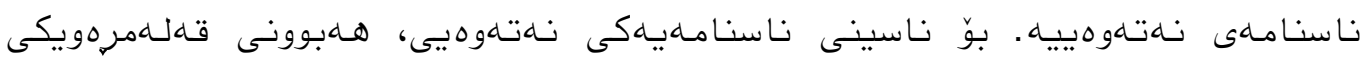

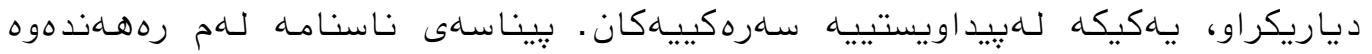

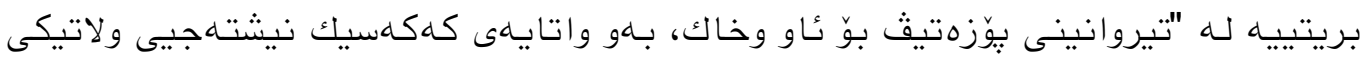

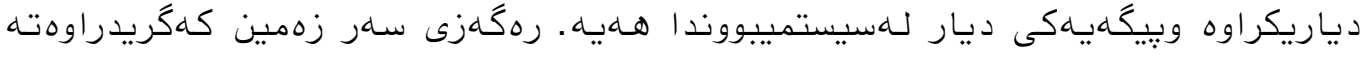

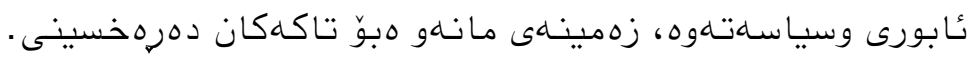

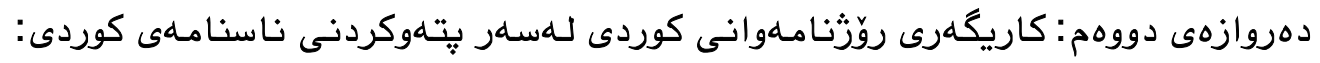

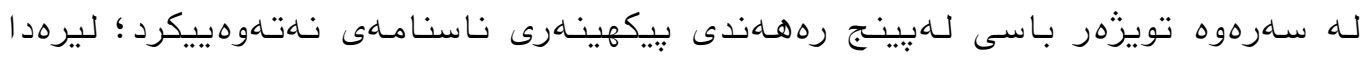

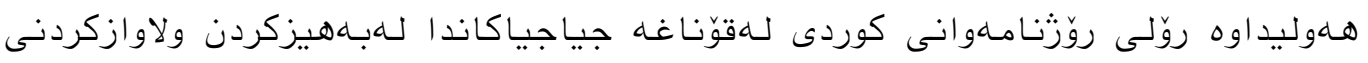

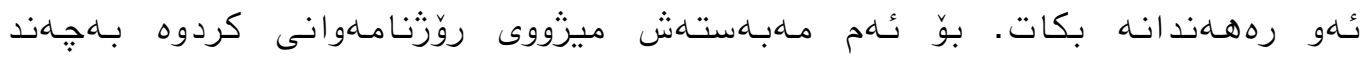

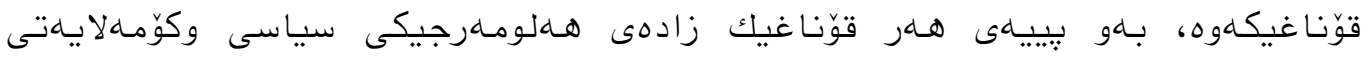

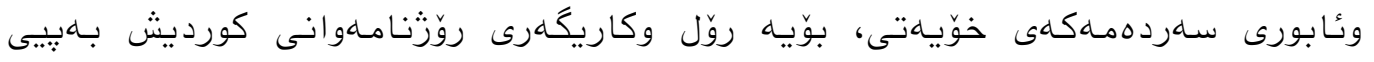

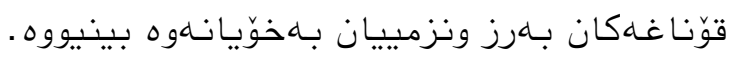

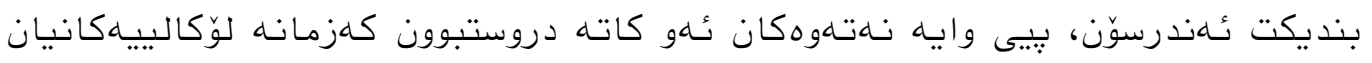

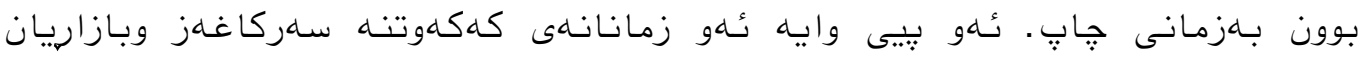

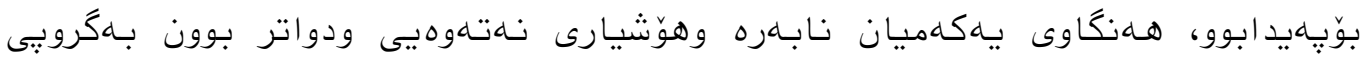

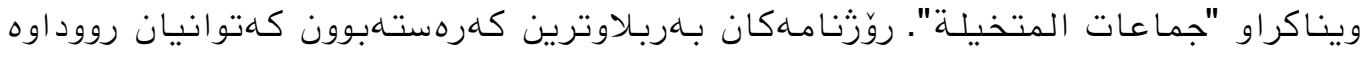

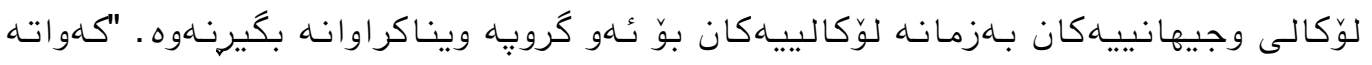

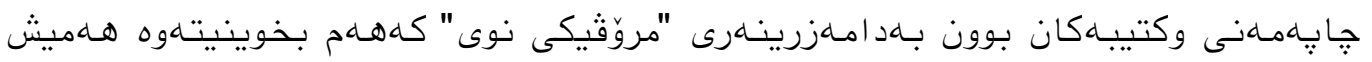

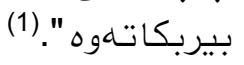

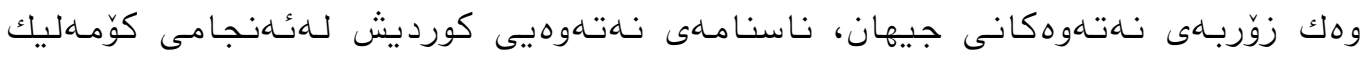

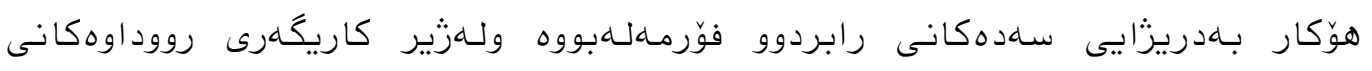

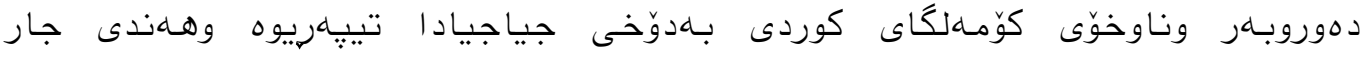

1. محمد تقى قزلسفلى، رسانه و ساخت هويت ملى، فصلنامه سياست. دوره 39 شماره 3، پايز 1388، ص 1332. 


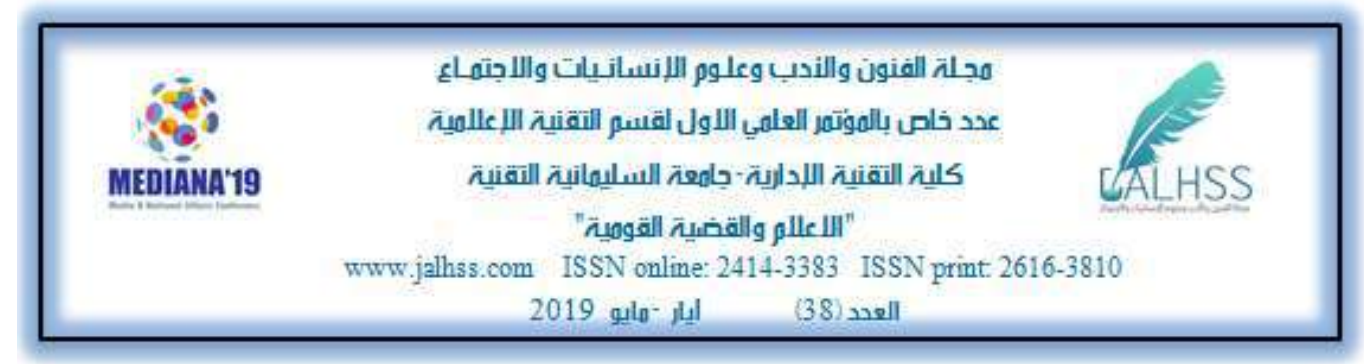

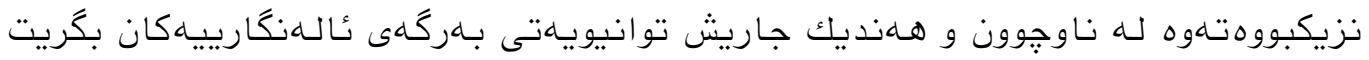

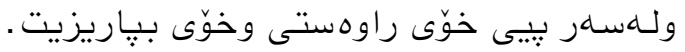

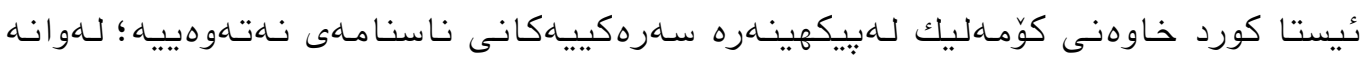

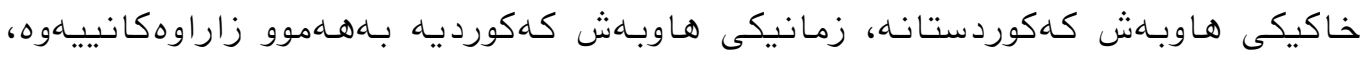

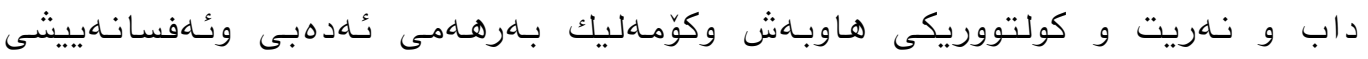

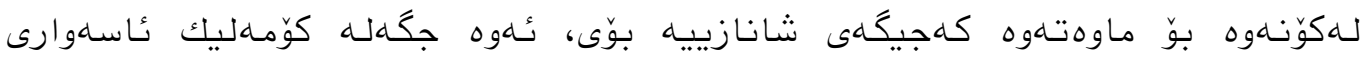

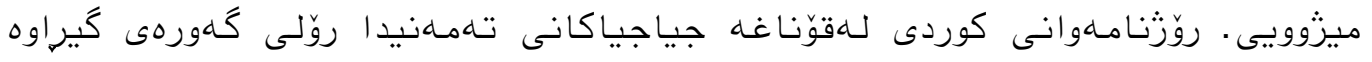

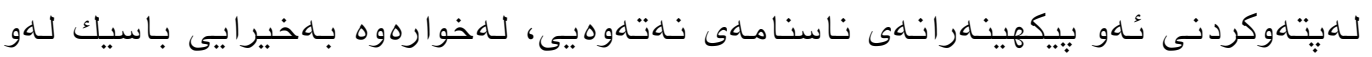
روّله ده كهنين.

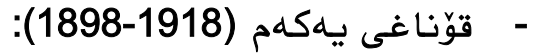

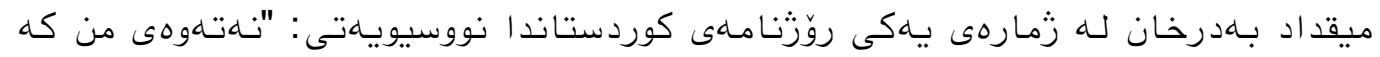

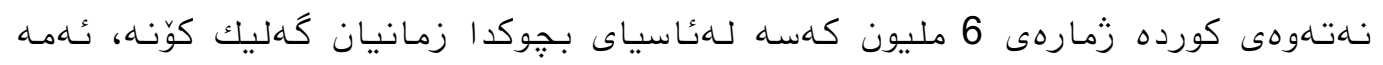

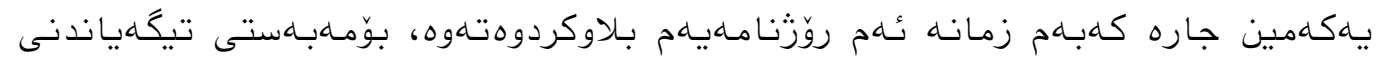

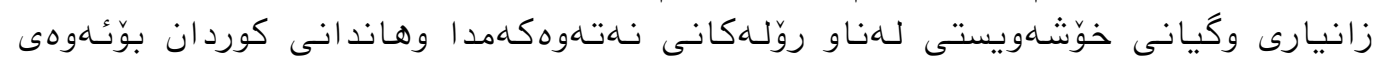

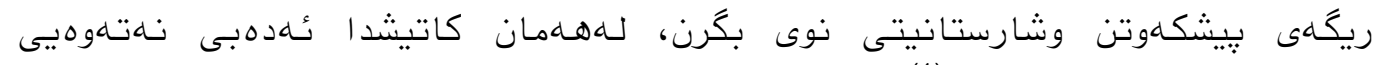

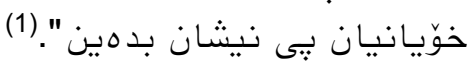

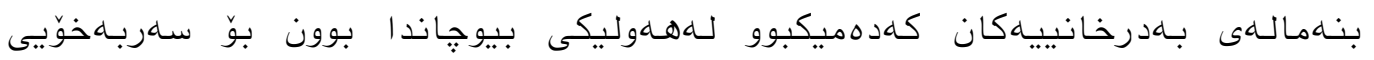

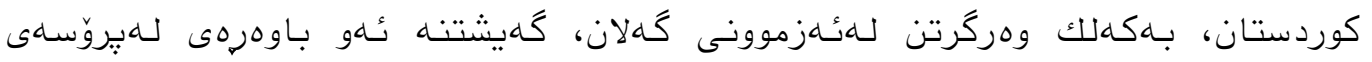

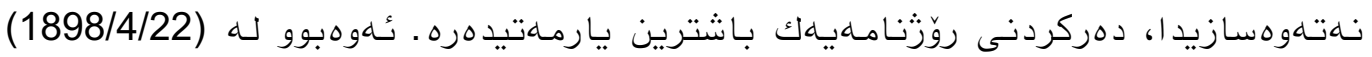

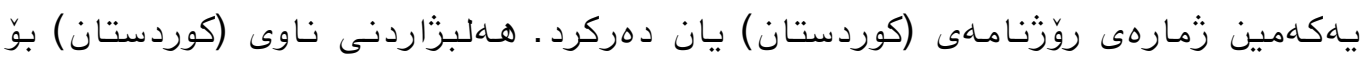

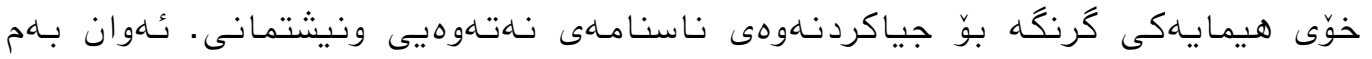

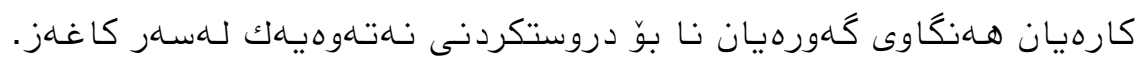

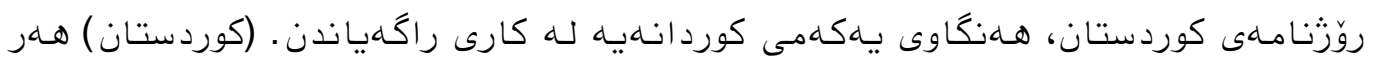

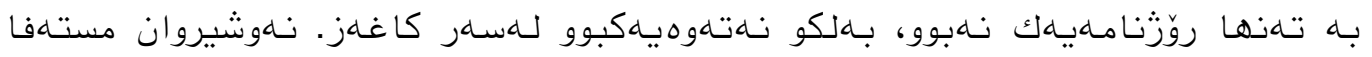

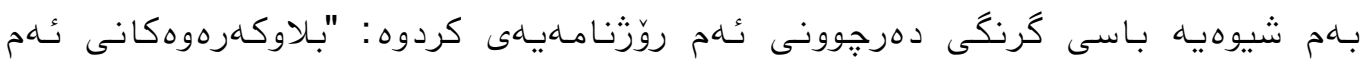

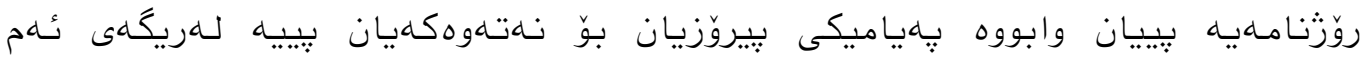

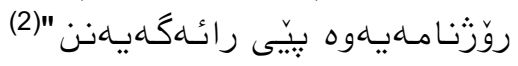

1. ميقداد بـادرخان، كوردستان، زماره 22، 1نيسانى 1892، لـ 1. (ئهو دهقه لـهلايهن نـهشيروان مستهفاوه

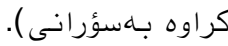

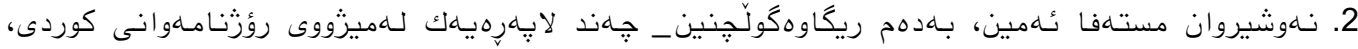

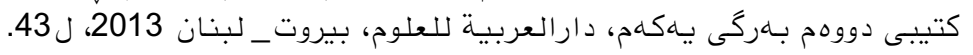




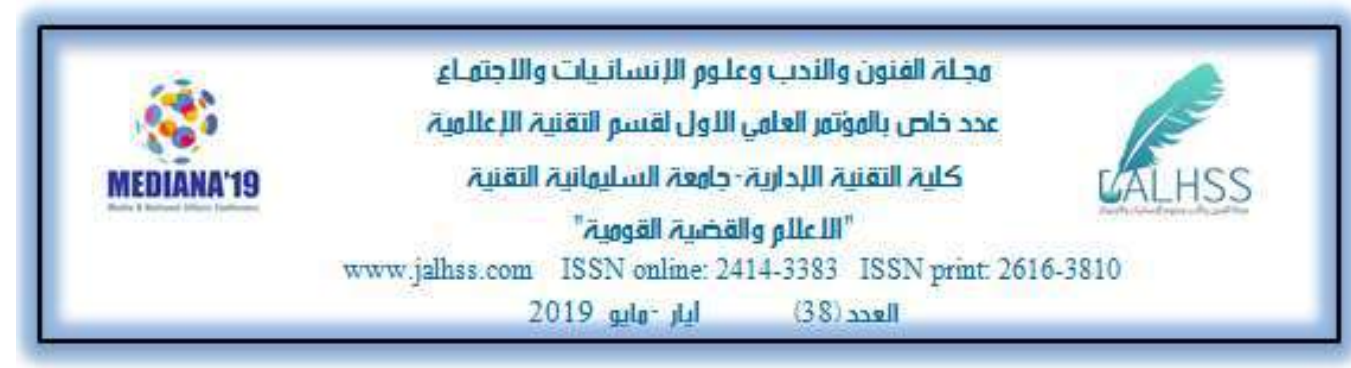

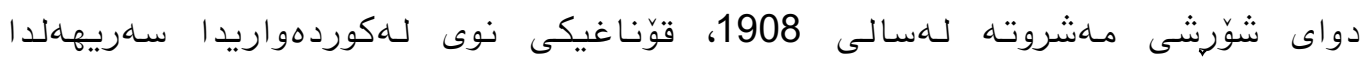

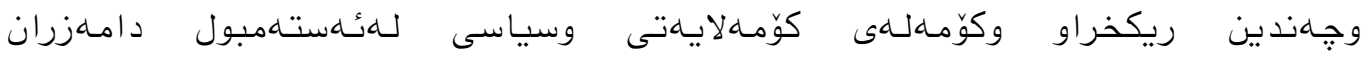

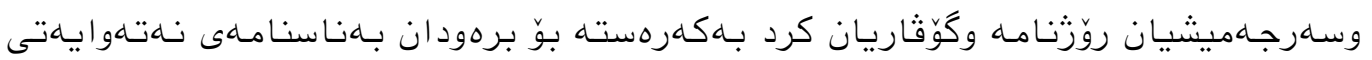

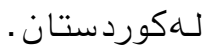
- موّناغى دووهم (1918-1923):

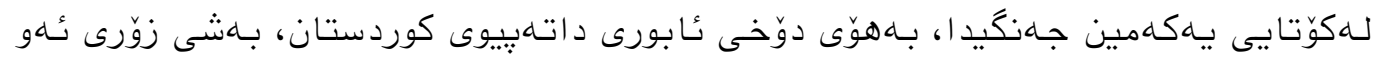

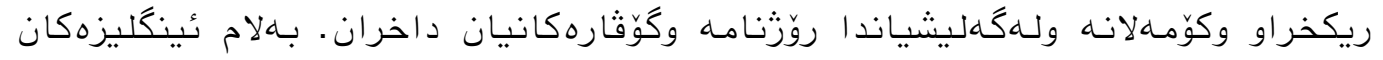

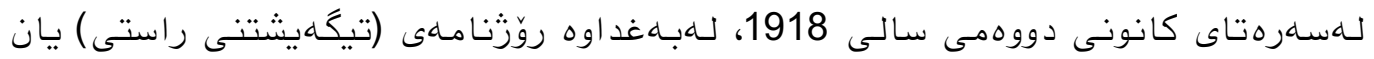

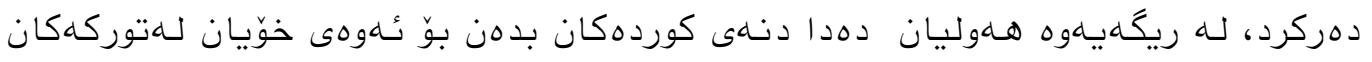

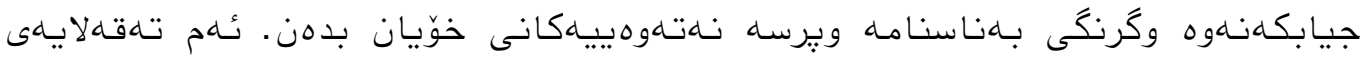

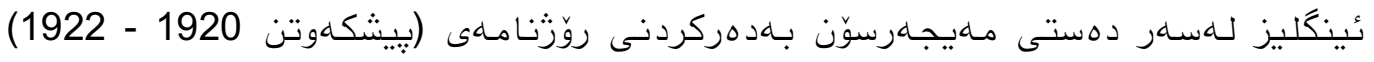

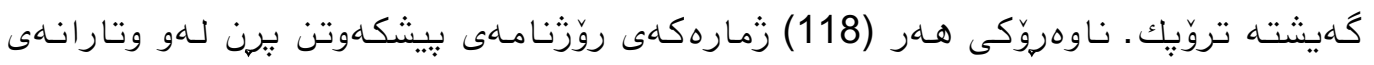

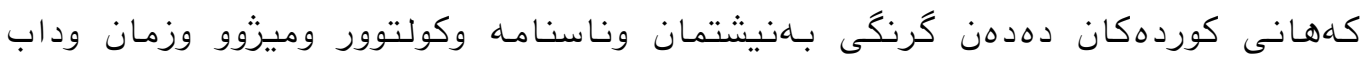

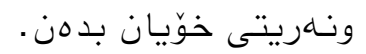

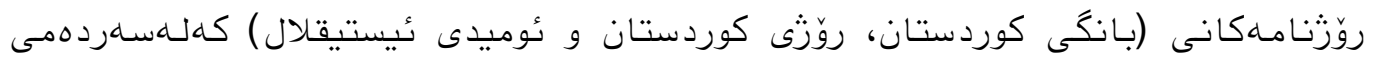

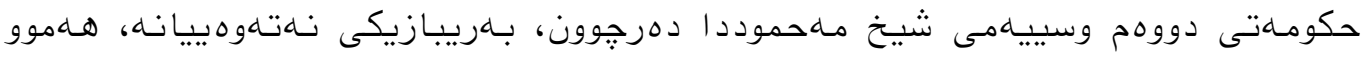

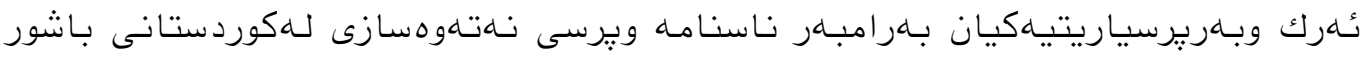

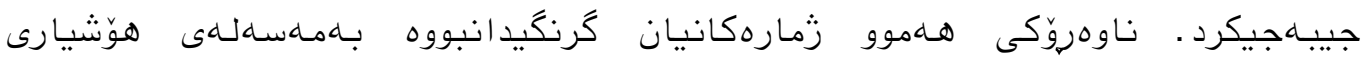

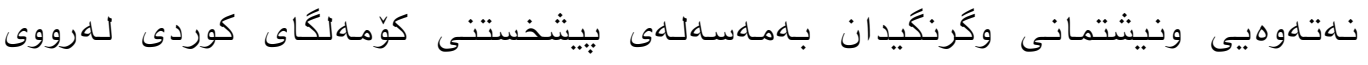

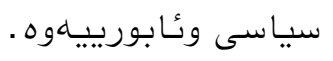

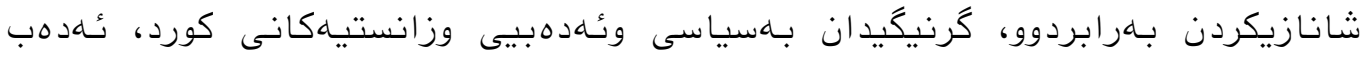

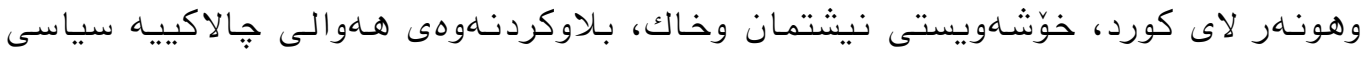

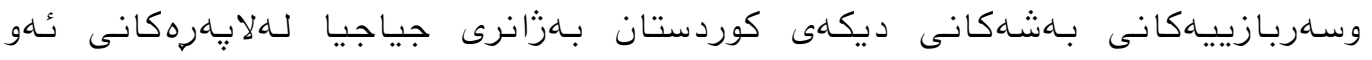

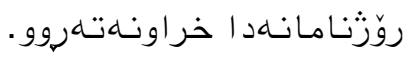

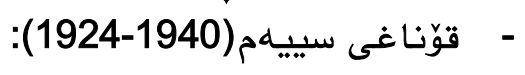

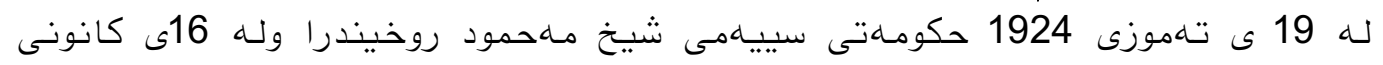

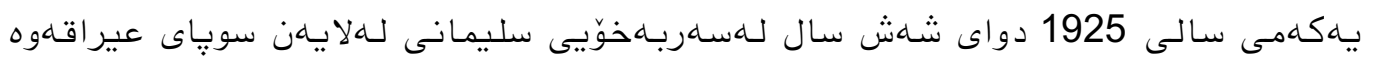

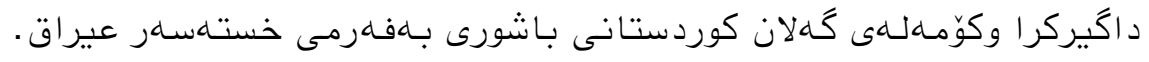

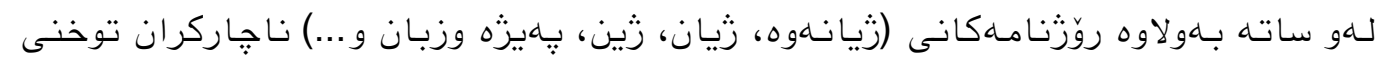

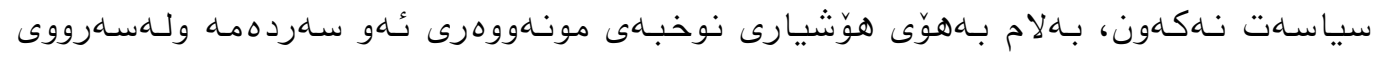

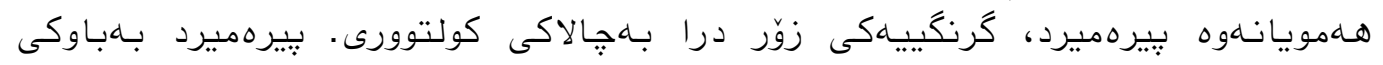




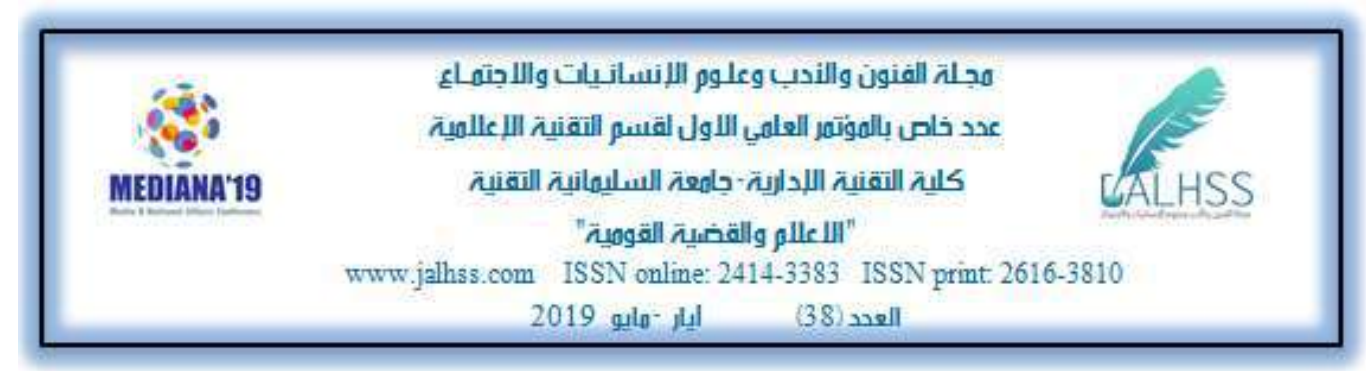

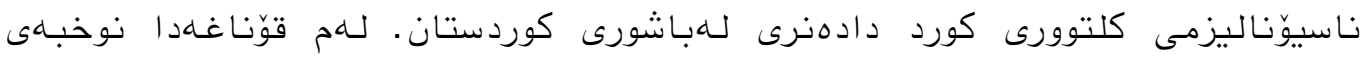

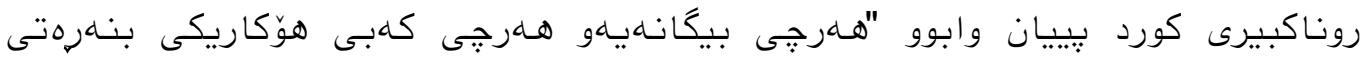

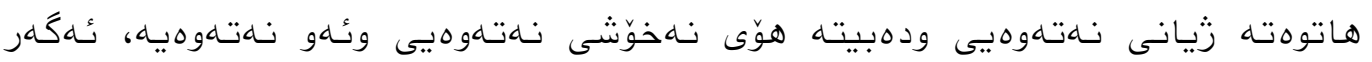

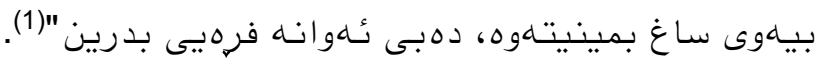

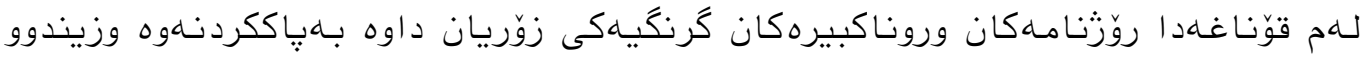

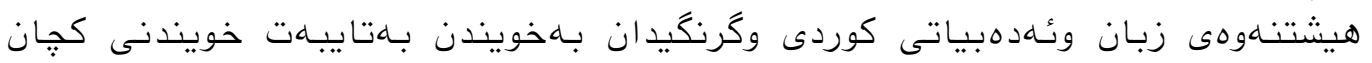

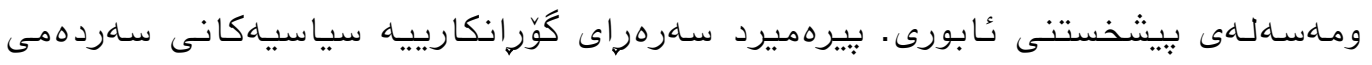

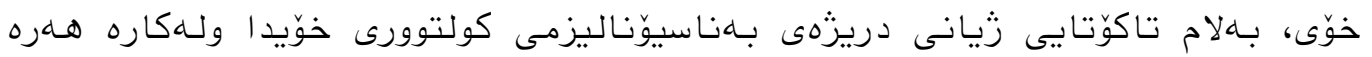

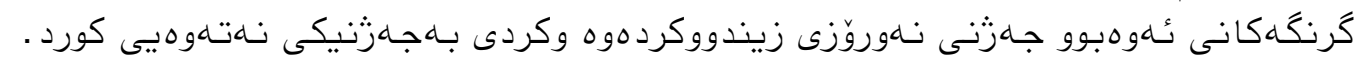

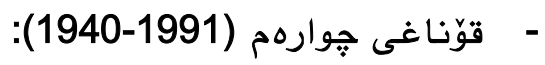

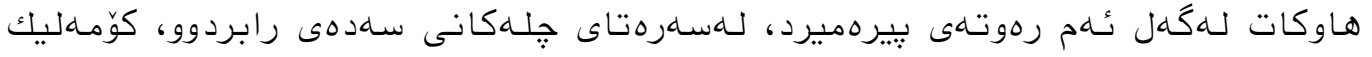

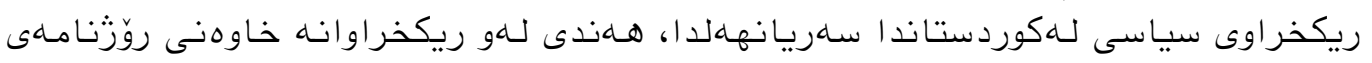

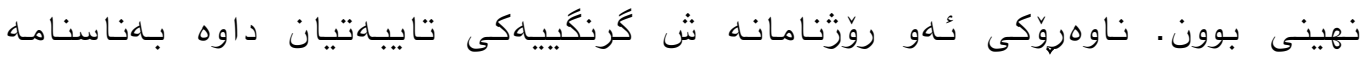

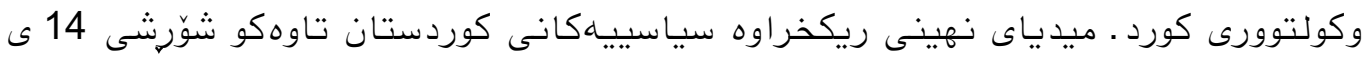

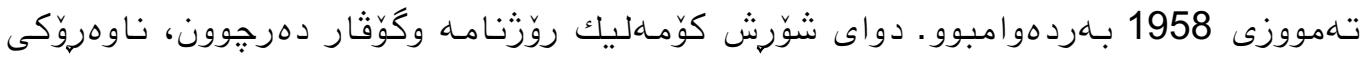

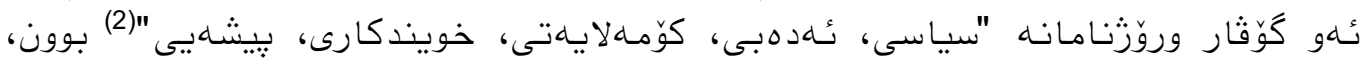

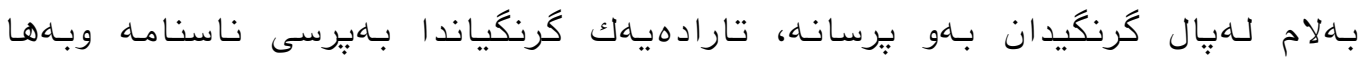

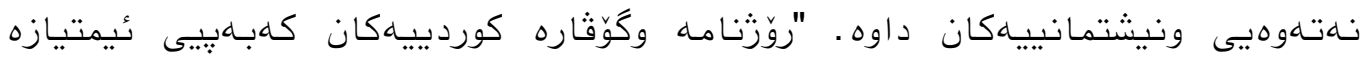

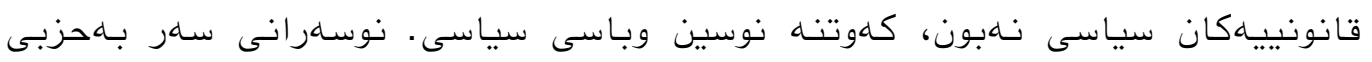

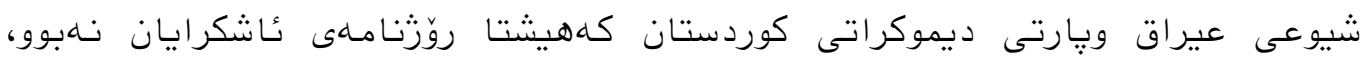

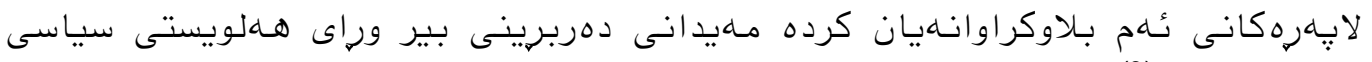

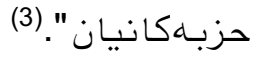

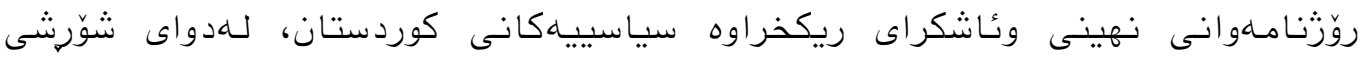

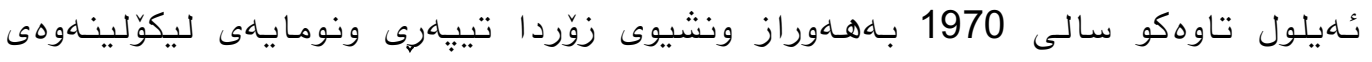

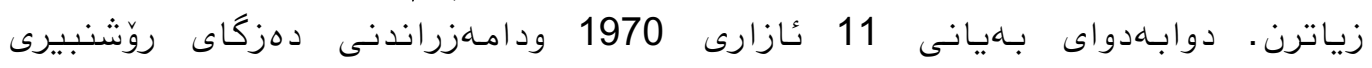

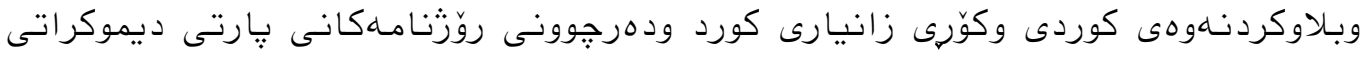

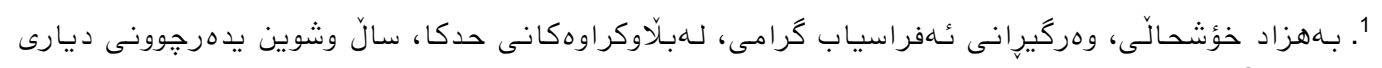

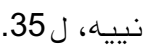

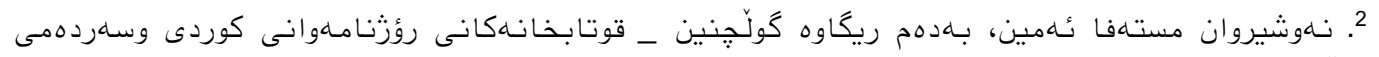

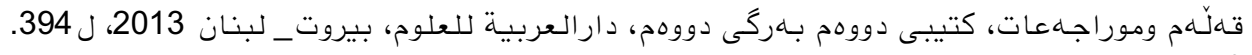

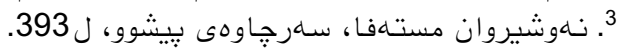




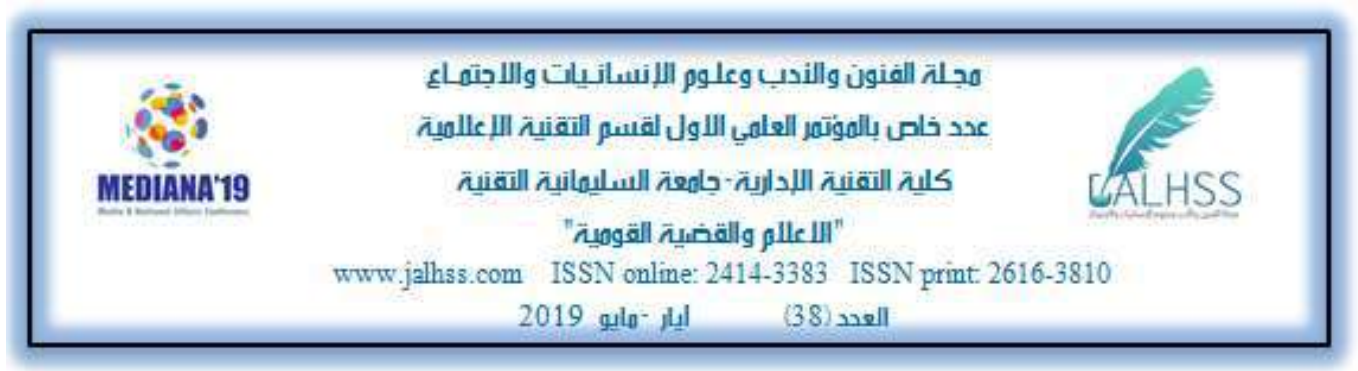

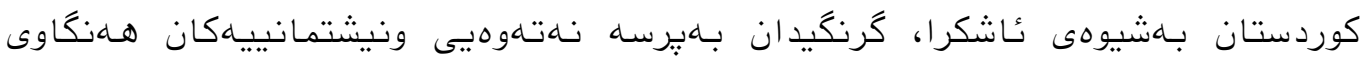

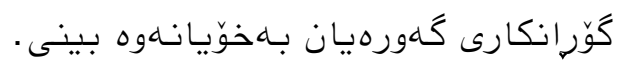

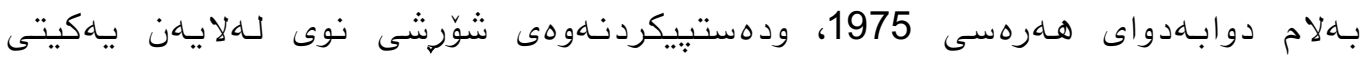

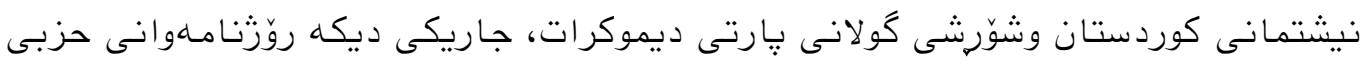

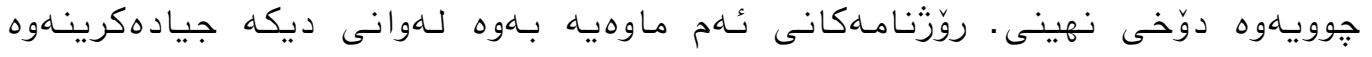

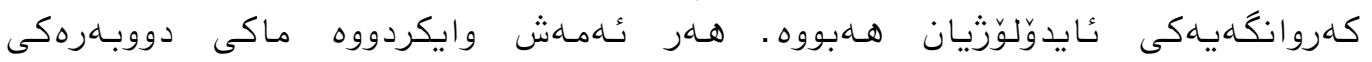

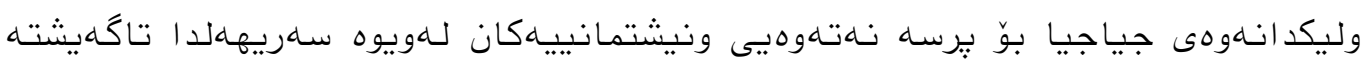

رابِهينى 1991.

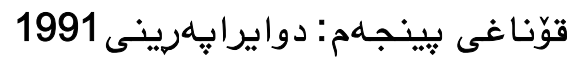

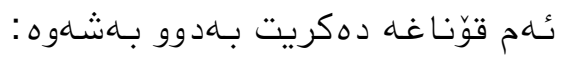

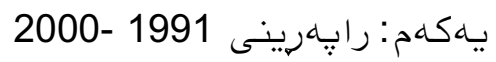

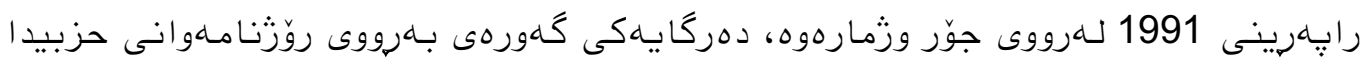

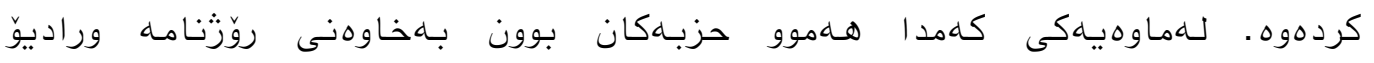

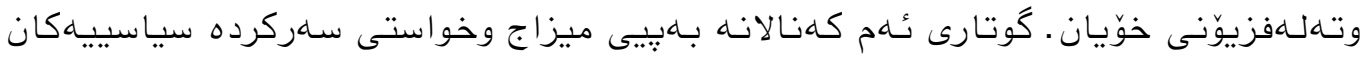

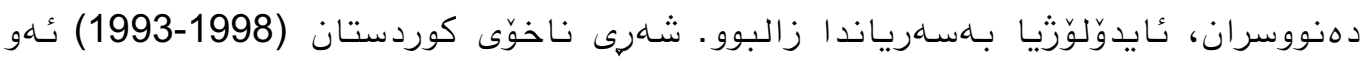

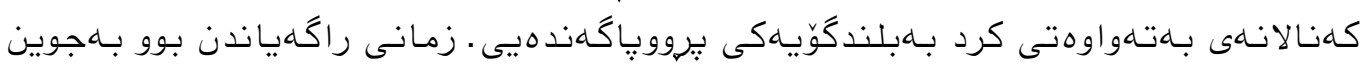

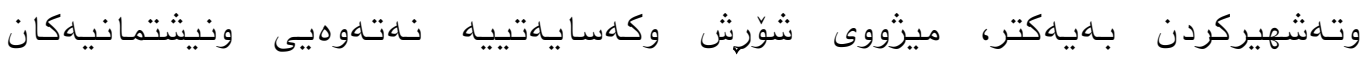

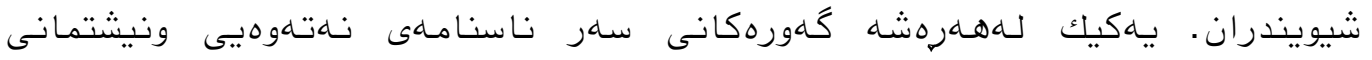

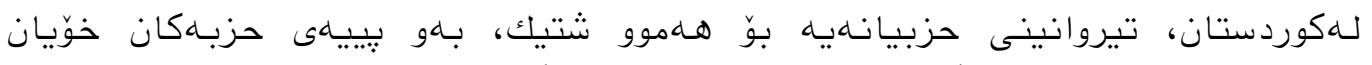

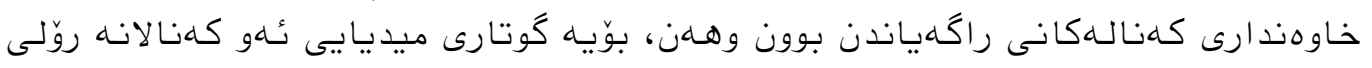

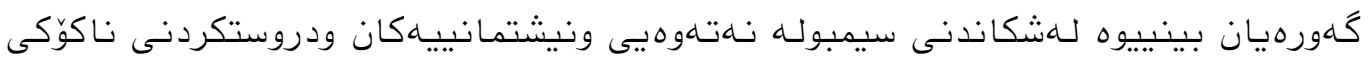

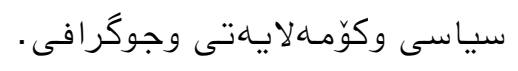

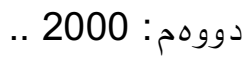

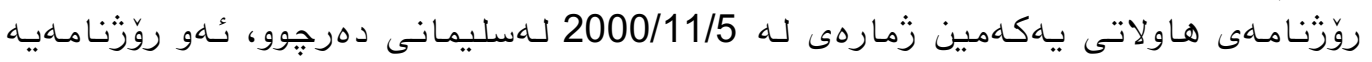

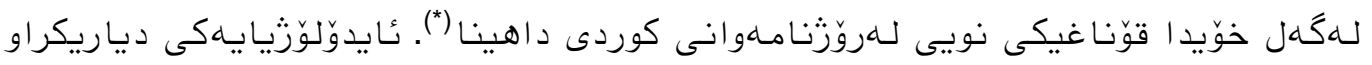

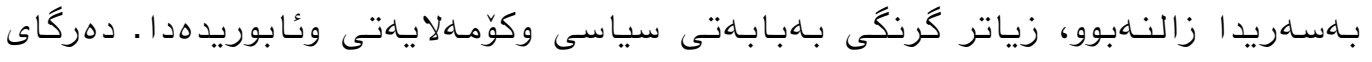

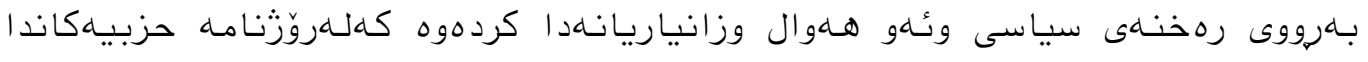

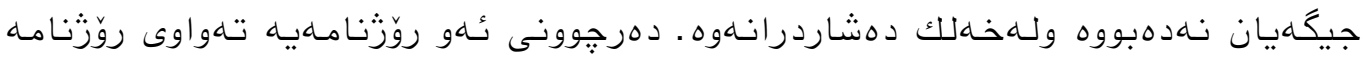

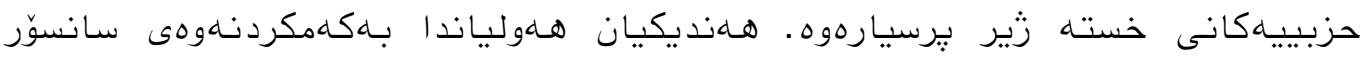

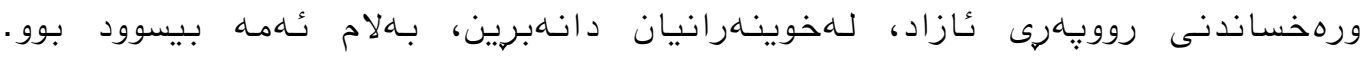

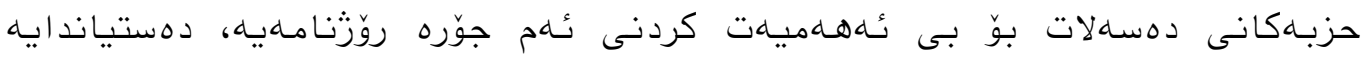


ising
هجلة الفنون والندب وعلوم اللإنسانيات واللاجِمهاع

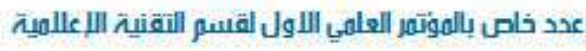

كلية التقنية اللدازية -جاهعت السليهانية التفنية

"

www.jalhss.com ISSN online: $2414-3383$ ISSN print $2616-3810$

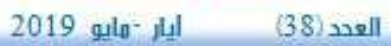

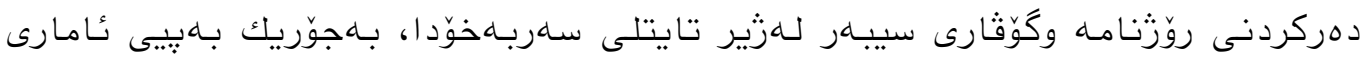

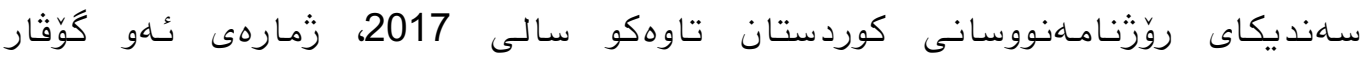

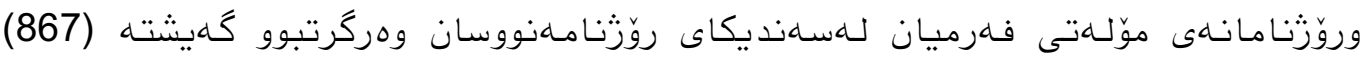

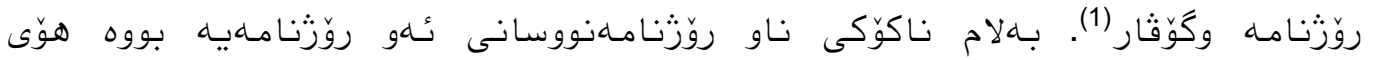

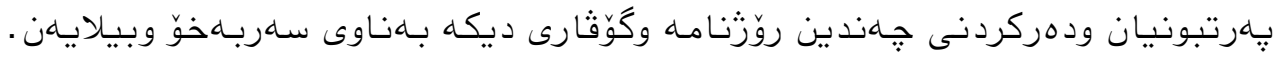

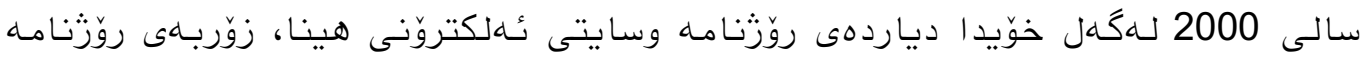

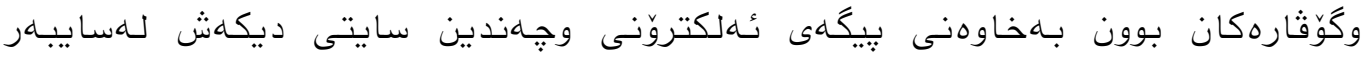

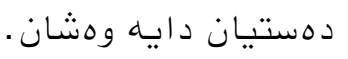

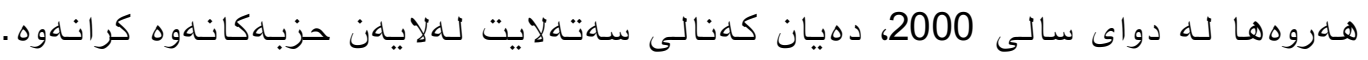

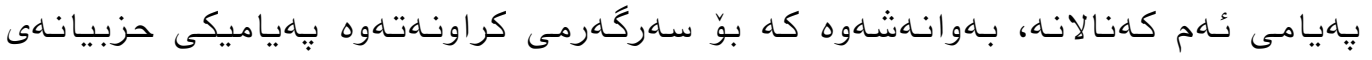

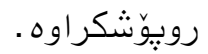

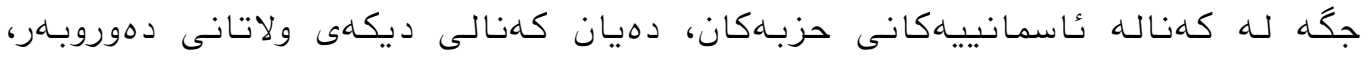

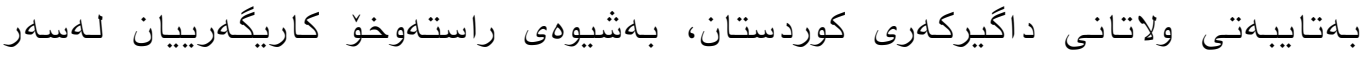

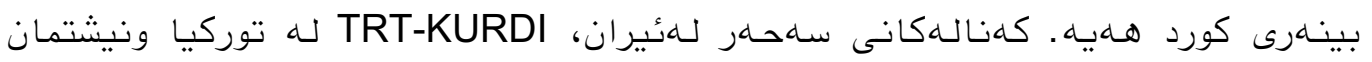

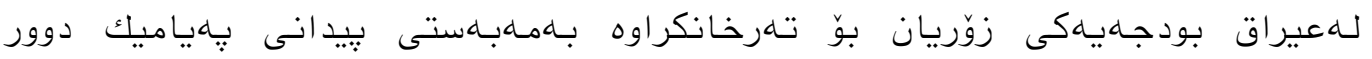

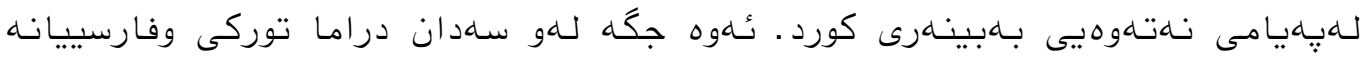

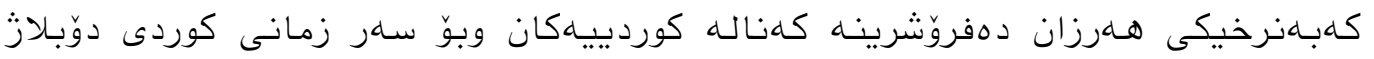

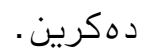

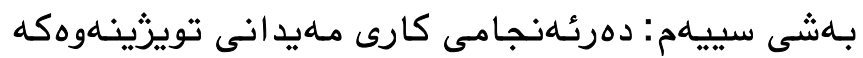

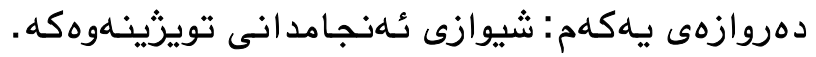

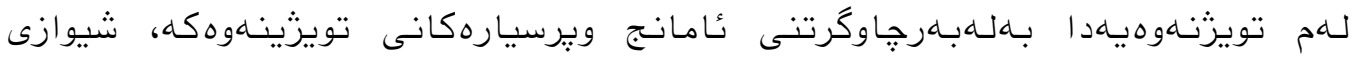

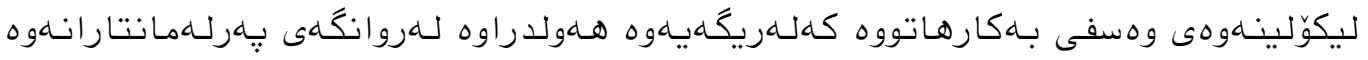

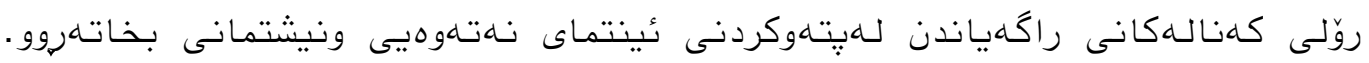

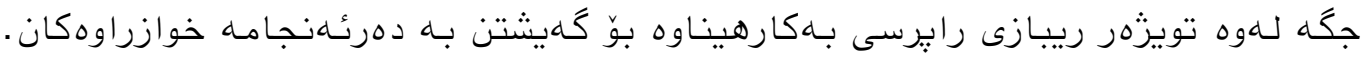

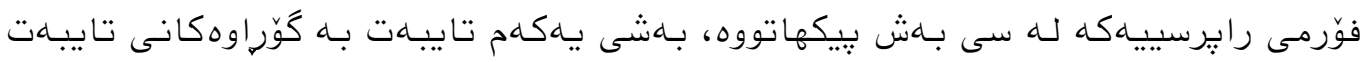

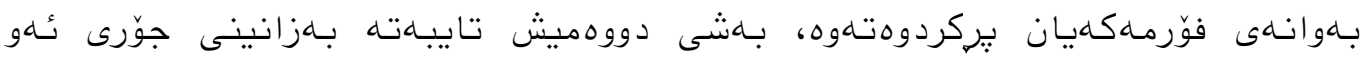

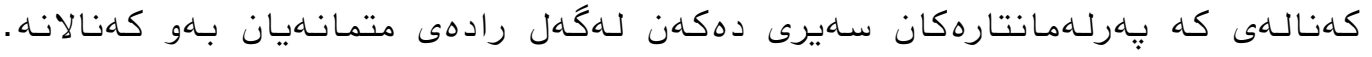

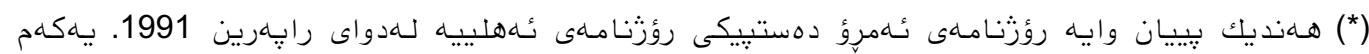

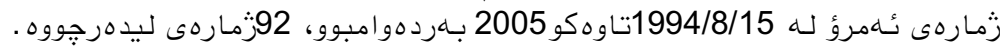

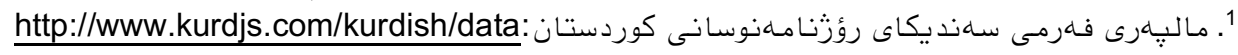




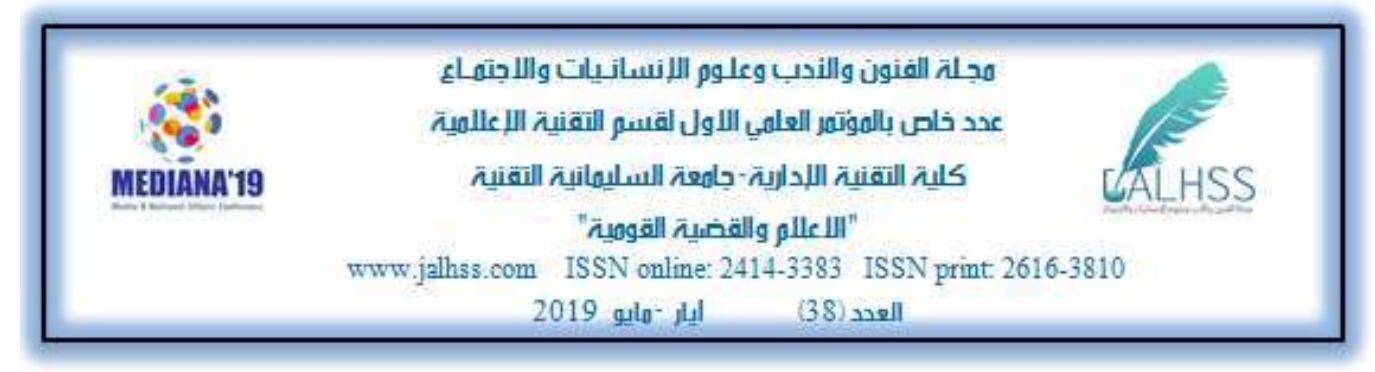

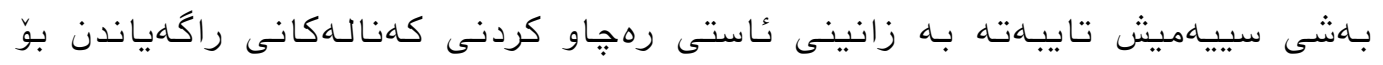

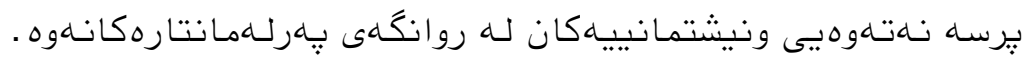

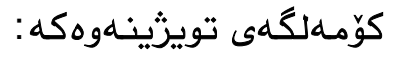

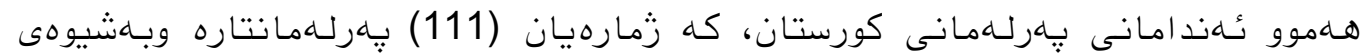

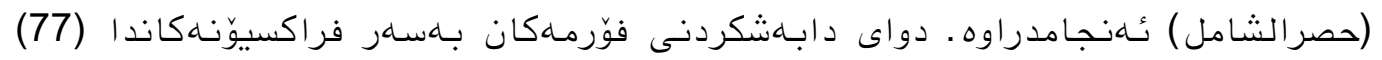

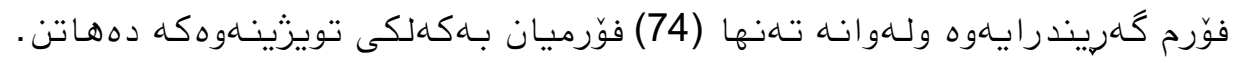

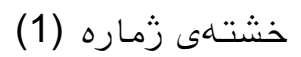

\begin{tabular}{|c|c|c|}
\hline ريزهى سهدى & زمـاره & رهكهز \\
\hline 64.9 & 48 & نير \\
\hline 35.1 & 26 & مى \\
\hline 100.0 & 74 & كوّى كُشتى \\
\hline
\end{tabular}

لهخشتهى زمـاره (1) دادهردهكهوى 57٪ بهاهد اربووانى رابرسييهكه لـهرهگهزى (نير) و43\%

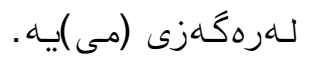
خشتهى زماره (2) نئاستى خوّيندن

\begin{tabular}{|c|c|c|}
\hline ريزهى سهدى & زمـاره & بروانـامه \\
\hline 2.7 & 2 & سهرهتايى \\
\hline 6.8 & 5 & ناوهندى \\
\hline 8.1 & 6 & ئامـادهيى \\
\hline 9.5 & 7 & دبلوَم \\
\hline 50.0 & 37 & بـهـالوَريوّس \\
\hline 13.5 & 10 & ماجستير \\
\hline 9.5 & 7 & دكتورَ \\
\hline 100.0 & 74 & كوّى كشتى \\
\hline
\end{tabular}

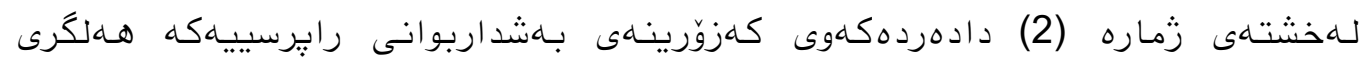

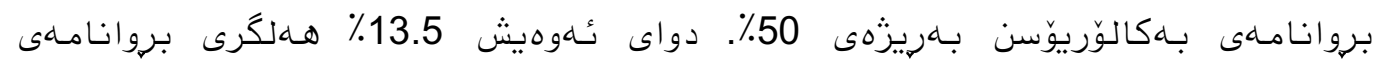

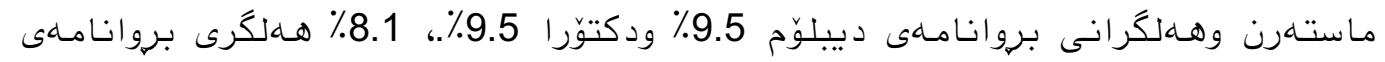

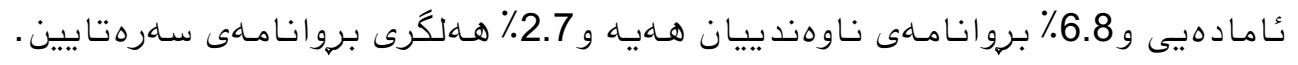




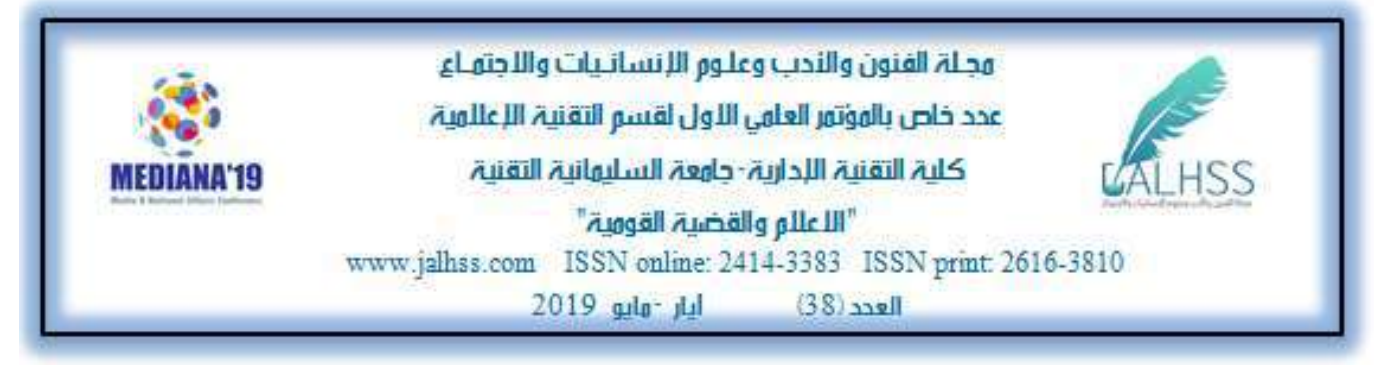

$$
\text { راستى فوّرمى رابِرسيهكه: }
$$

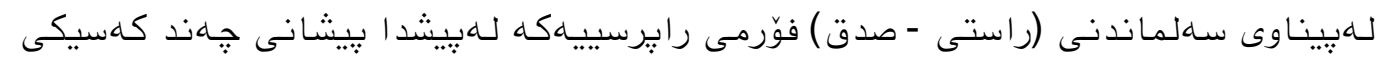

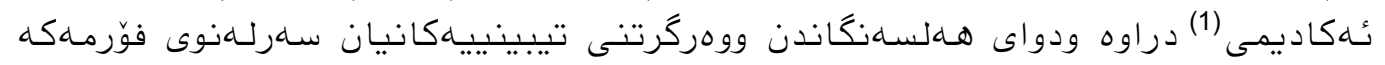

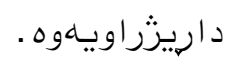
جاره سهارى ئامارى:

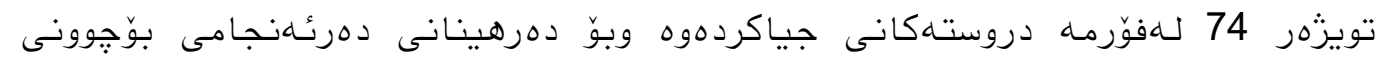

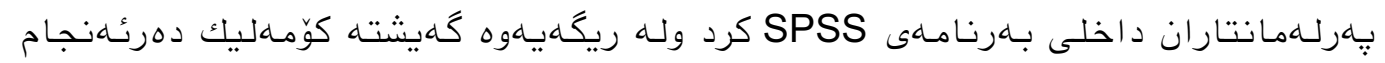

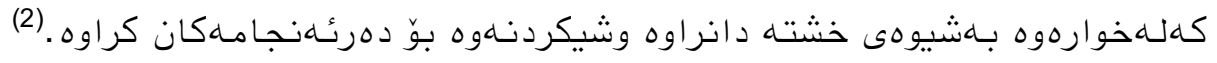
دهروازهى دووهم: تويزينهوهى مهيدانى ودهرئهنجـام وراسباردهكان:

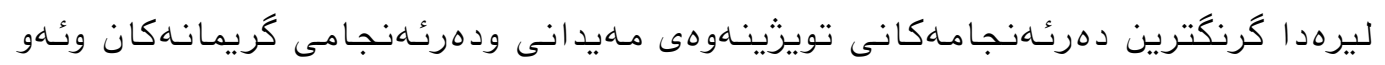

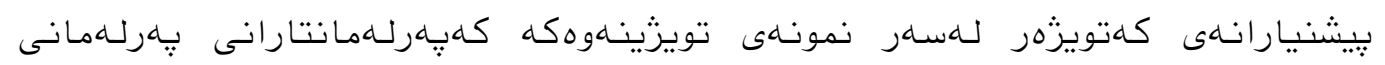

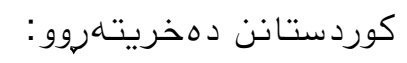
يهكلم. دهرئهنجامى تويزينهوهى مهيد انى:

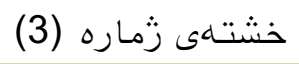

\begin{tabular}{|c|c|c|}
\hline ريزهى سـدى & زماره & 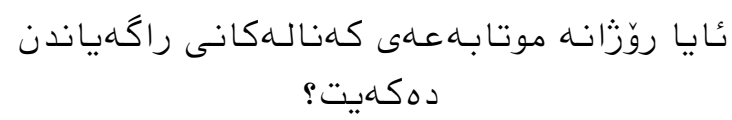 \\
\hline 97.3 & 72 & بهلى \\
\hline 2.7 & 2 & نهخير \\
\hline
\end{tabular}

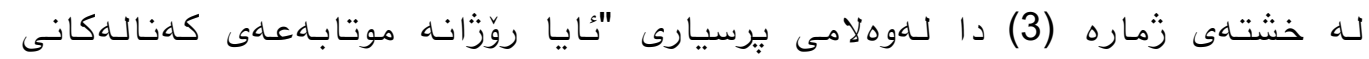

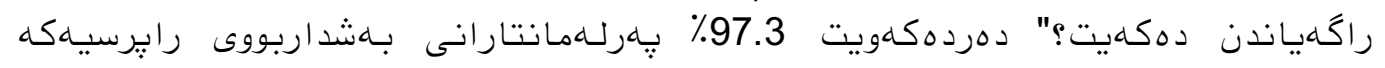

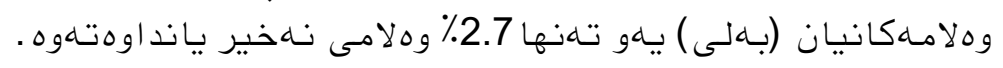

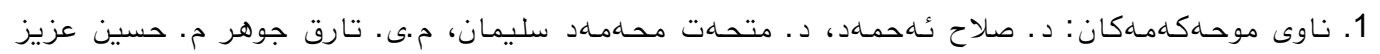

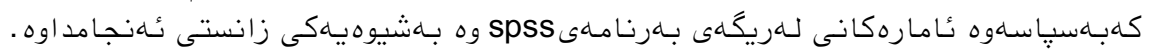

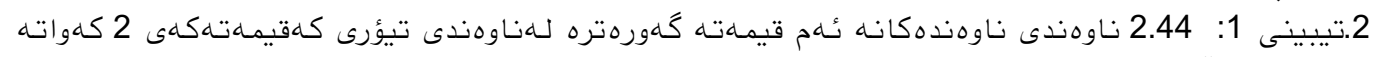

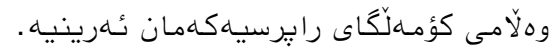

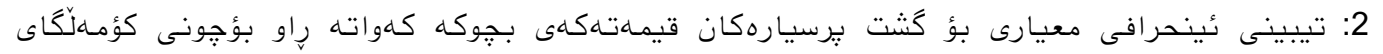

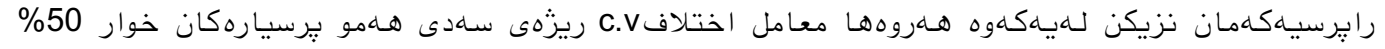

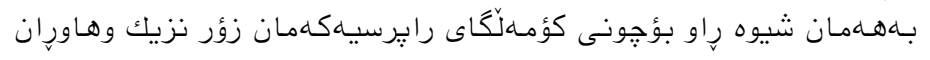




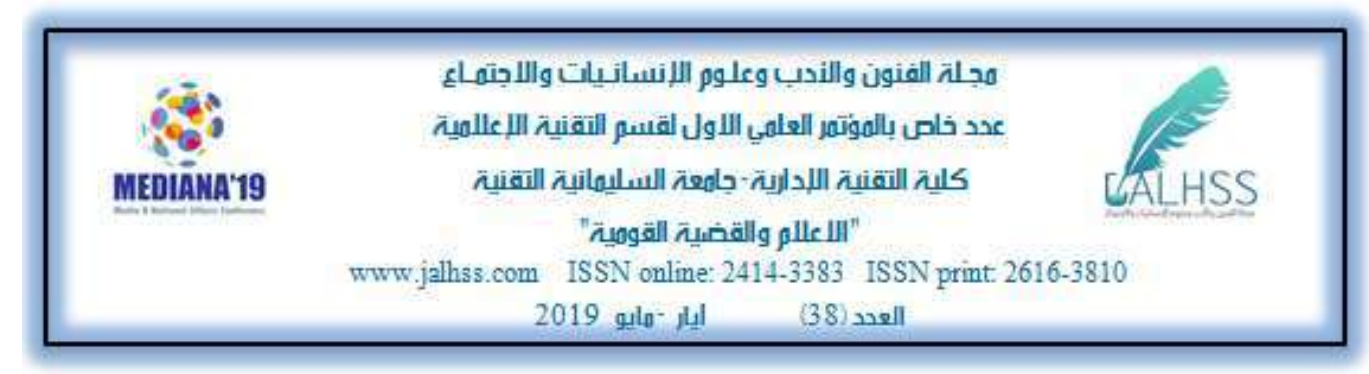

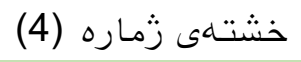

\begin{tabular}{|c|c|c|c|}
\hline ريزهى سـدى & \multicolumn{2}{|c|}{ زماره } & 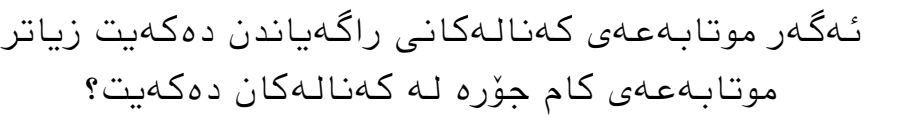 \\
\hline 9.5 & \multicolumn{2}{|c|}{7} & روّزَنامـه \\
\hline 79.7 & \multicolumn{2}{|c|}{59} & تيظى TV \\
\hline 8.1 & \multicolumn{2}{|c|}{6} & راديو \\
\hline 2.7 & \multicolumn{2}{|c|}{2} & ميديدياى ئهلكتروّنى \\
\hline 100.0 & \multicolumn{2}{|c|}{74} & كوّى كَشتى \\
\hline \multicolumn{4}{|c|}{ 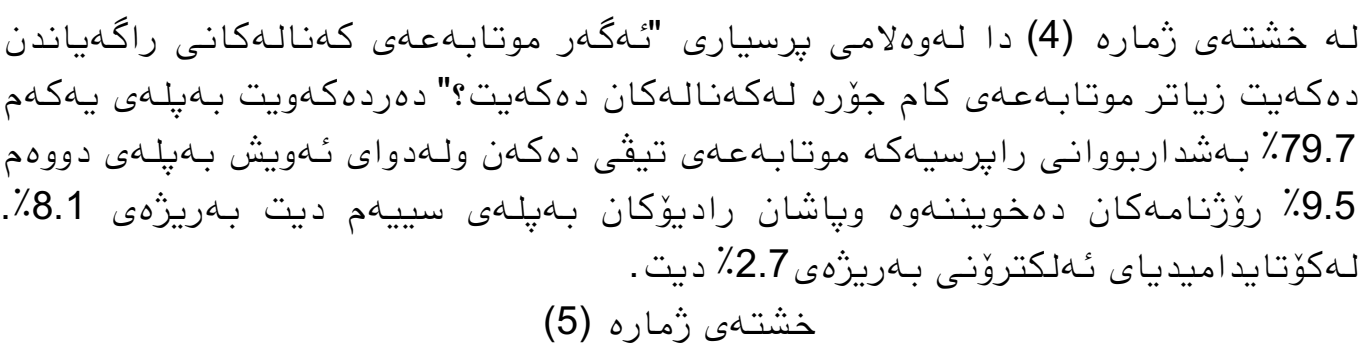 } \\
\hline \multicolumn{2}{|c|}{ ريزهى سهدى } & زماره & 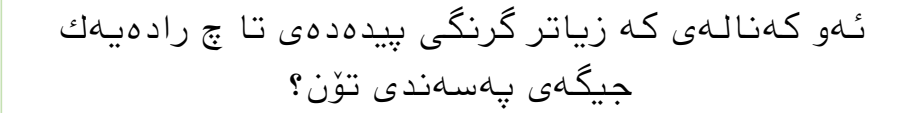 \\
\hline \multicolumn{2}{|l|}{4.1} & 3 & كهم \\
\hline \multicolumn{2}{|l|}{74.3} & 55 & تارادهيهك \\
\hline \multicolumn{2}{|l|}{17.6} & 13 & زَوْر \\
\hline \multicolumn{2}{|l|}{4.1} & 3 & زَوَرزوّر \\
\hline \multicolumn{2}{|l|}{100.0} & 74 & كوّى كُشتى \\
\hline
\end{tabular}

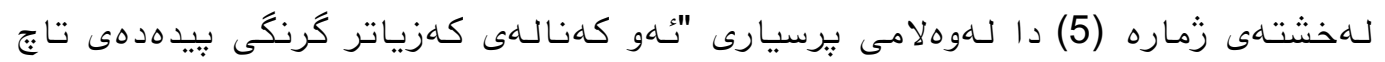

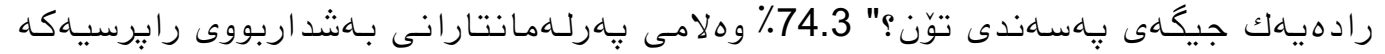

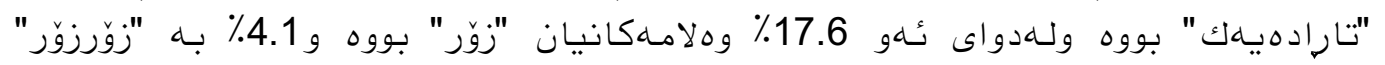

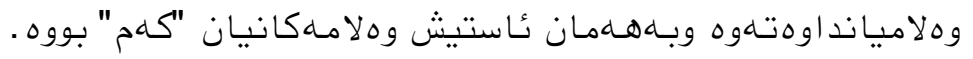

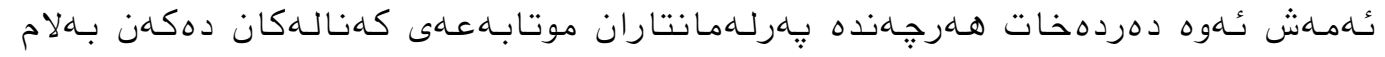

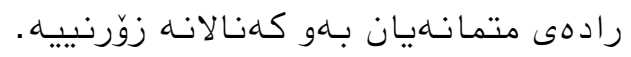




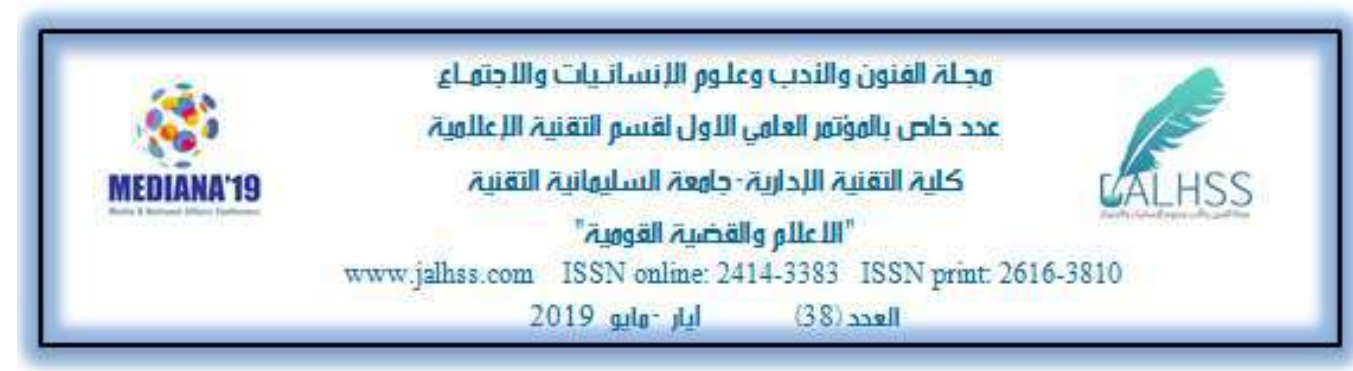

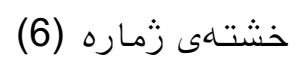

\begin{tabular}{|c|c|c|c|c|c|c|c|c|c|}
\hline \multicolumn{2}{|c|}{ زوّرخراب } & \multicolumn{2}{|c|}{ خراب } & \multicolumn{2}{|c|}{ 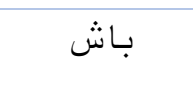 } & \multicolumn{2}{|c|}{ 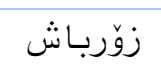 } & \multirow{2}{*}{ 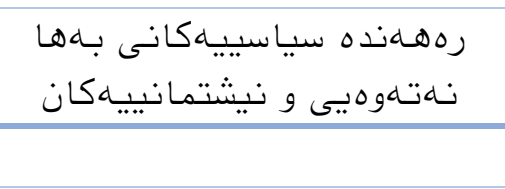 } & \multirow[t]{2}{*}{ j } \\
\hline$\%$ & $\dot{j}$ & $\%$ & $\dot{j}$ & $\%$ & $\dot{j}$ & $\%$ & $\dot{j}$ & & \\
\hline 4.1 & 3 & 44.6 & 33 & 39.2 & 29 & 12.2 & 9 & ئينتمـا بوّ كوردستان & 1 \\
\hline 6.8 & 5 & 31.1 & 23 & 58.1 & 43 & 4.1 & 3 & كرنگيدان به سئازادى جـالاكى & 2 \\
\hline 17.6 & 13 & 56.8 & 42 & 24.3 & 18 & 1.4 & 1 & هـهرهشهى لايهنـهكان بوّ دوو & 3 \\
\hline 13.5 & 10 & 50.0 & 37 & 29.7 & 22 & 6.8 & 5 & 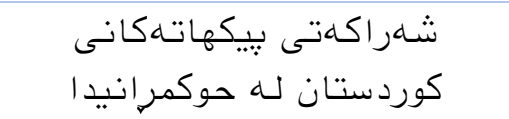 & 4 \\
\hline 24.3 & 18 & 47.3 & 35 & 23.0 & 17 & 5.4 & 4 & ناشيرين كردنى خيانهتى & 5 \\
\hline 12.2 & 9 & 44.6 & 33 & 35.1 & 26 & 8.1 & 6 & دامهزراندنى حوكمرانيهكى بـاش & 6 \\
\hline 18.9 & 14 & 52.7 & 39 & 17.6 & 13 & 10.8 & 8 & 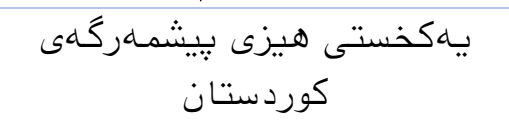 & 7 \\
\hline 4.1 & 3 & 35.1 & 26 & 55.4 & 41 & 5.4 & 4 & 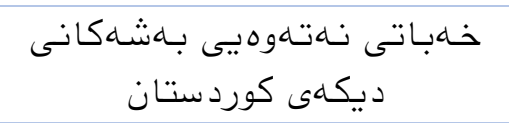 & 8 \\
\hline
\end{tabular}

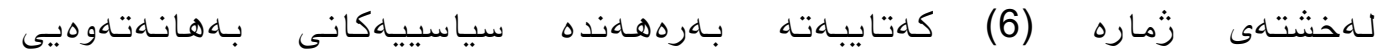

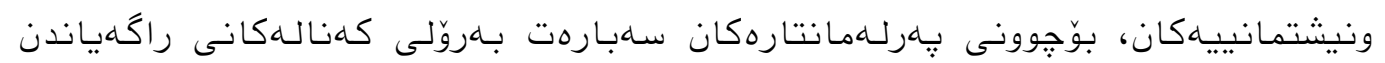

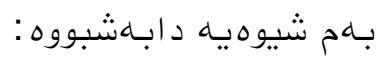

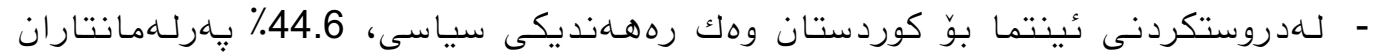

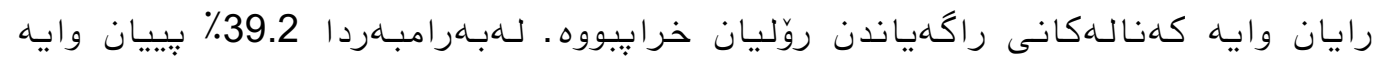

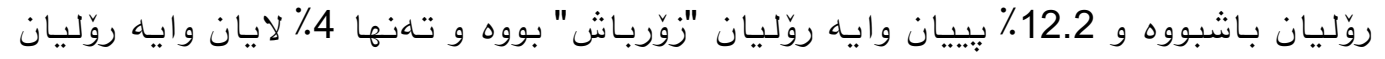

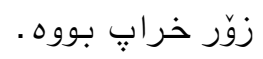

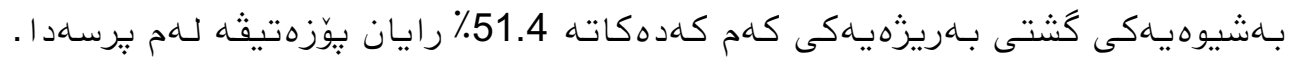

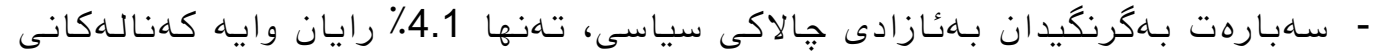

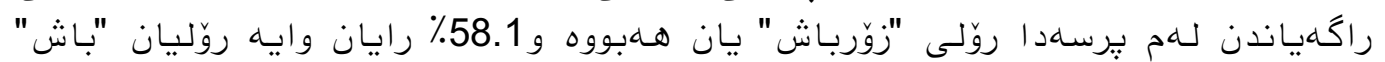

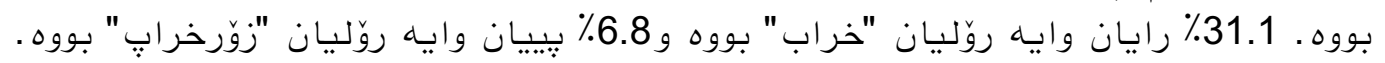

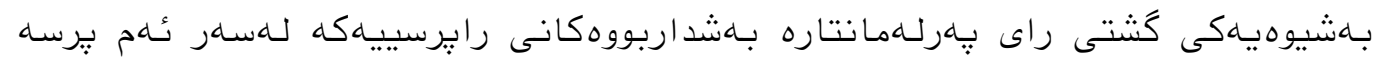

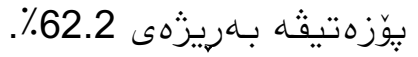




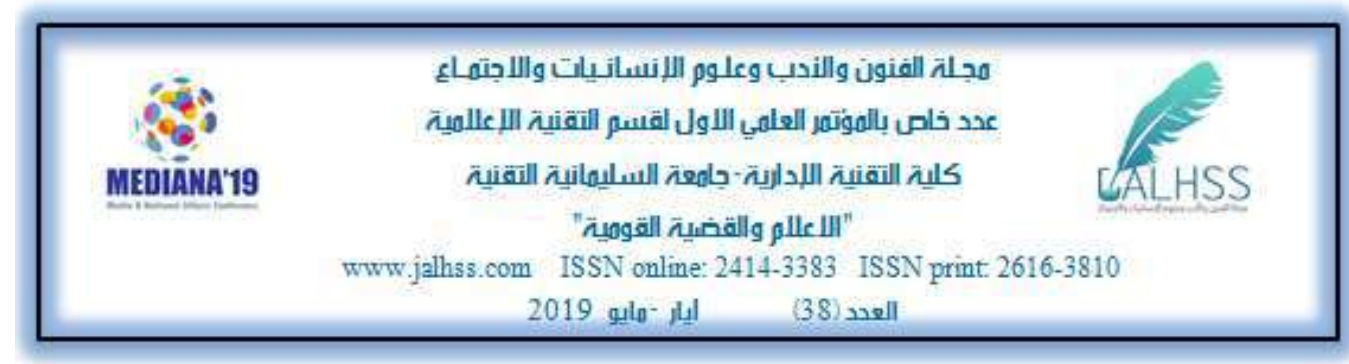

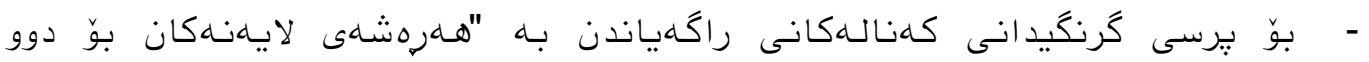

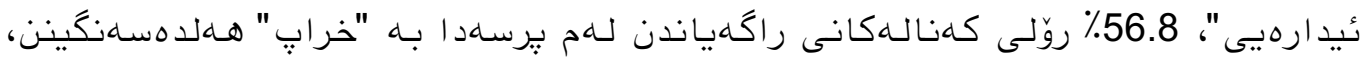

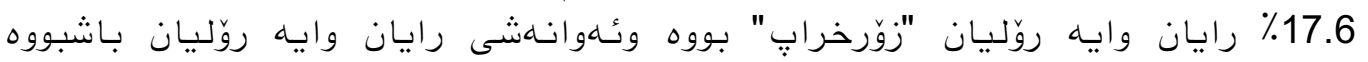

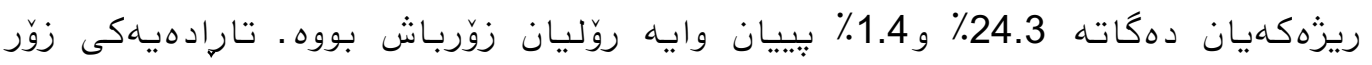

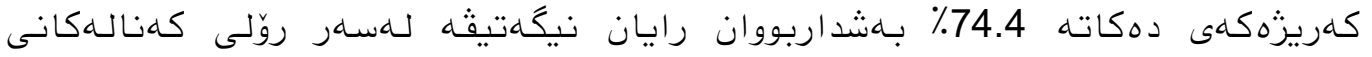

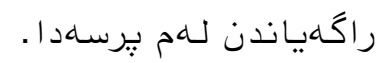

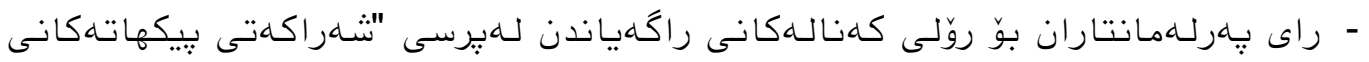

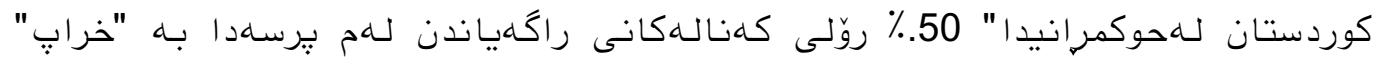

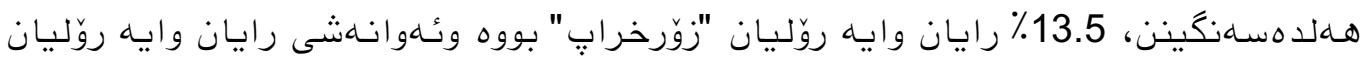

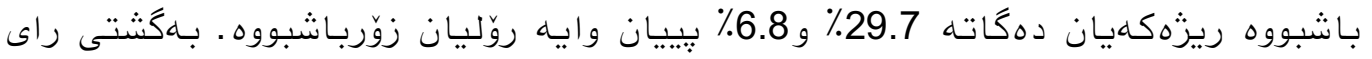

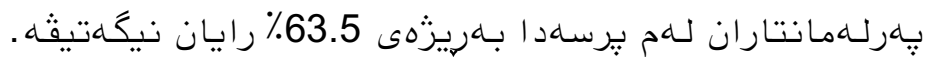

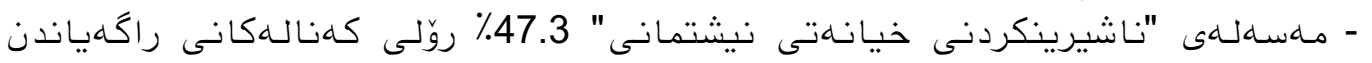

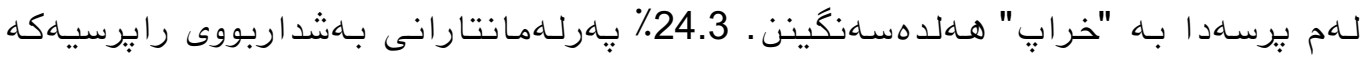

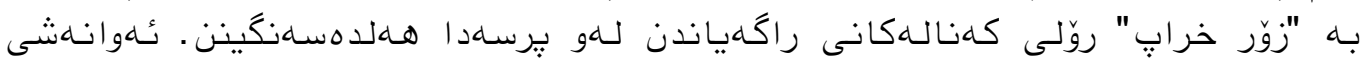

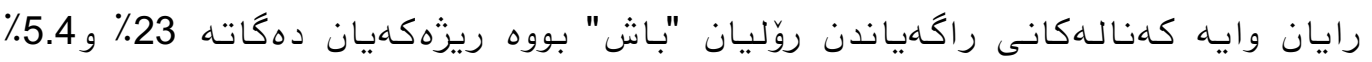

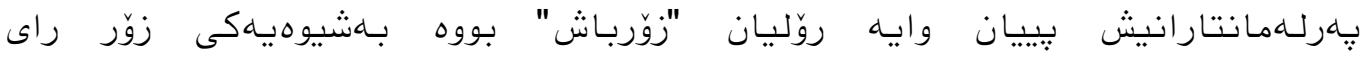

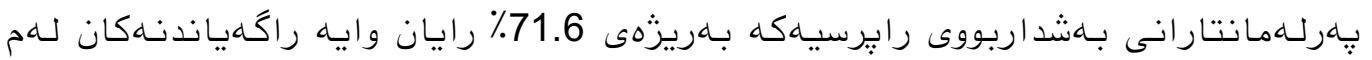

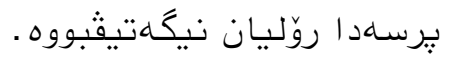

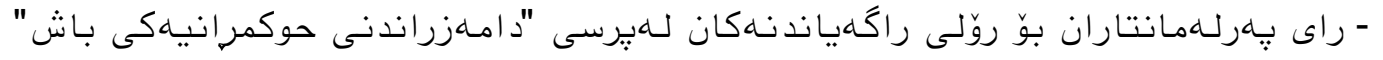

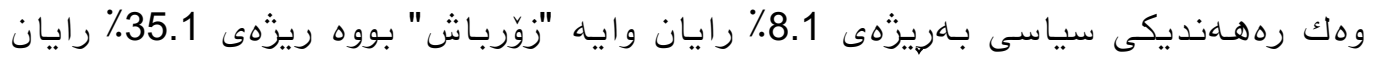

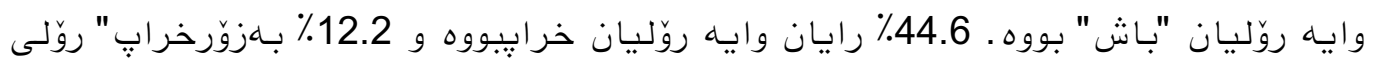

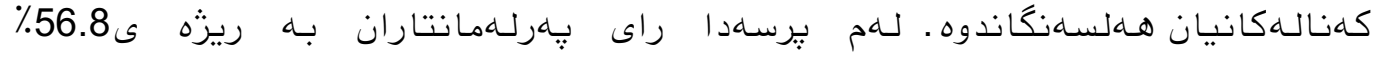

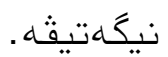

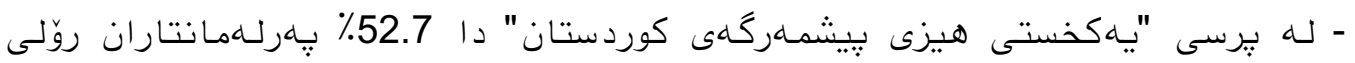

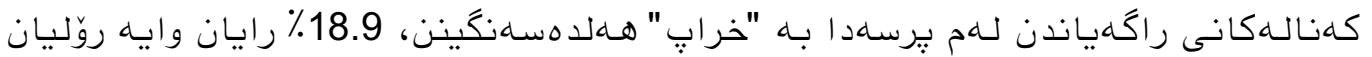

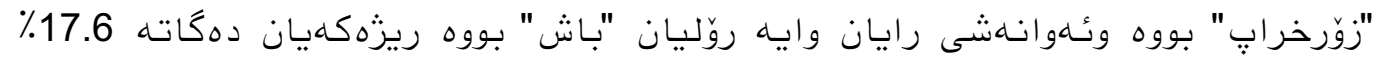

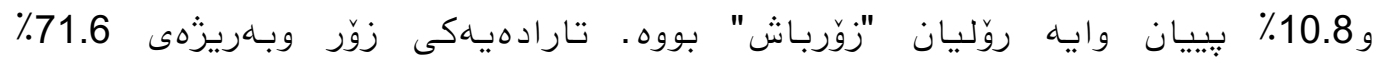

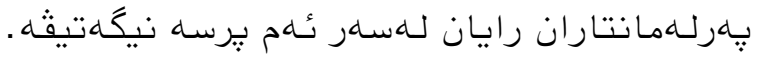

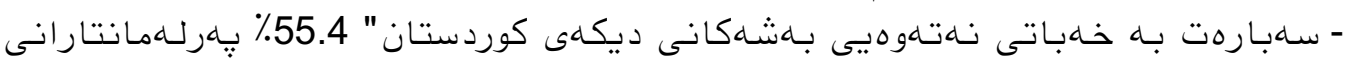

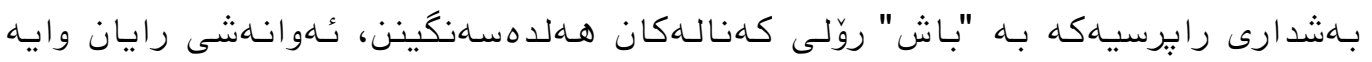

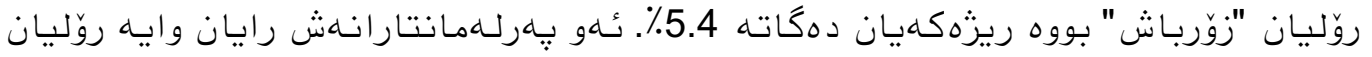




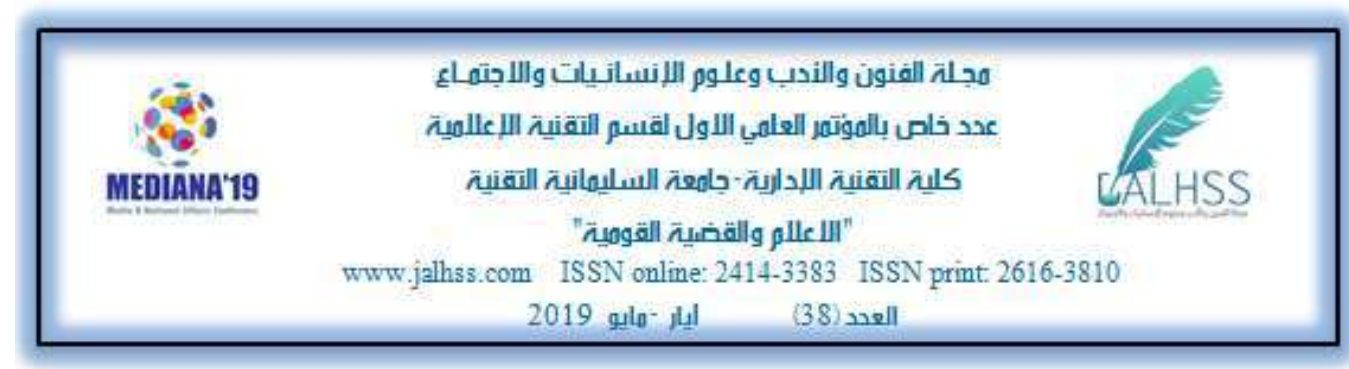

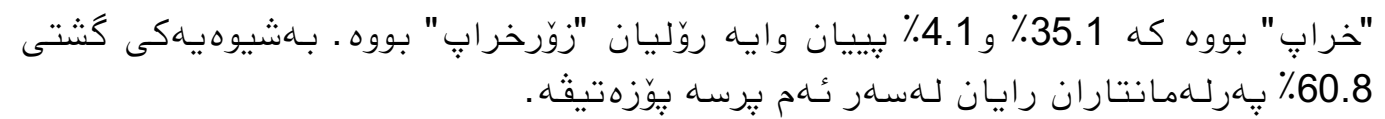

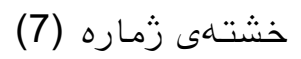

\begin{tabular}{|c|c|c|c|c|c|c|c|c|c|}
\hline \multicolumn{2}{|c|}{ زوّرخراب } & \multicolumn{2}{|c|}{ خراب } & \multicolumn{2}{|c|}{ باش } & \multicolumn{2}{|c|}{ زوّربـاش } & \multirow{2}{*}{ 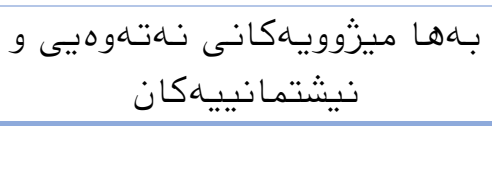 } & \multirow[t]{2}{*}{ j } \\
\hline$\%$ & j & $\%$ & ز & $\%$ & $\dot{j}$ & $\%$ & j & & \\
\hline 4.1 & 3 & 24.3 & 18 & 52.7 & 39 & 18.9 & 14 & 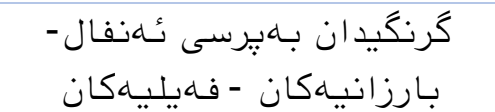 & 1 \\
\hline 6.8 & 5 & 50.0 & 37 & 33.8 & 25 & 9.5 & 7 & كرنگيد ان بـه ميزثووى كورد و كوردستان & 2 \\
\hline 13.5 & 10 & 31.1 & 23 & 44.6 & 33 & 10.8 & 8 & 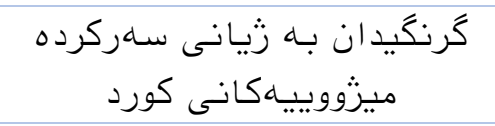 & 3 \\
\hline
\end{tabular}

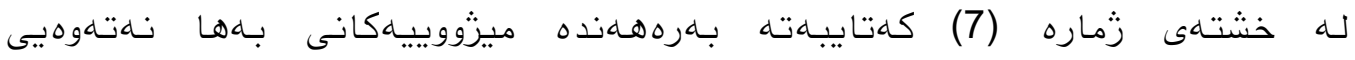

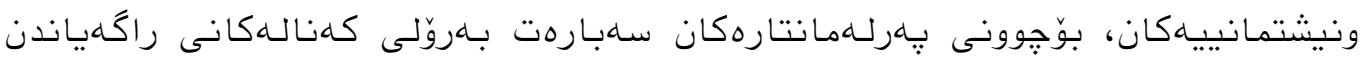

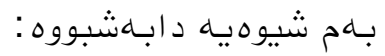

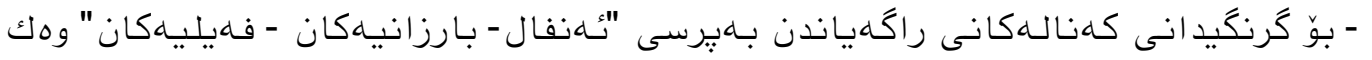

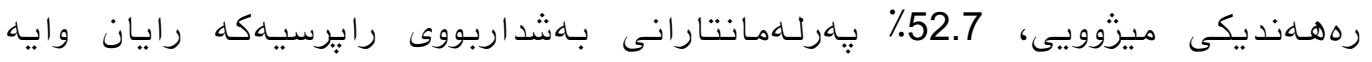

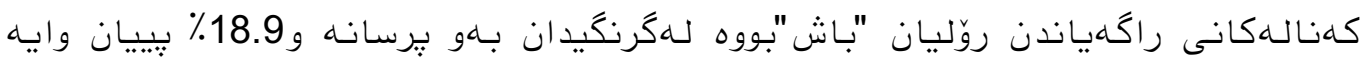

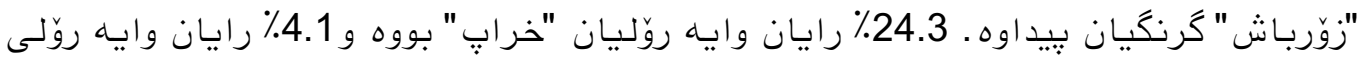

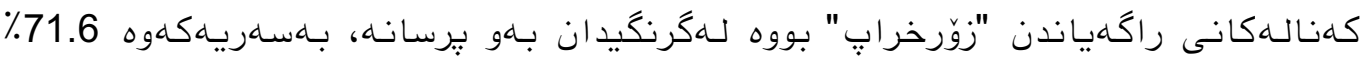

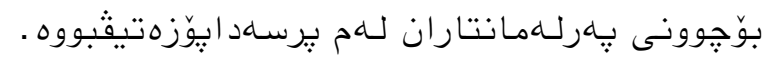

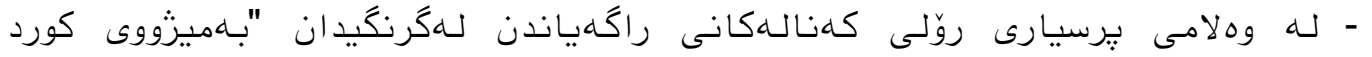

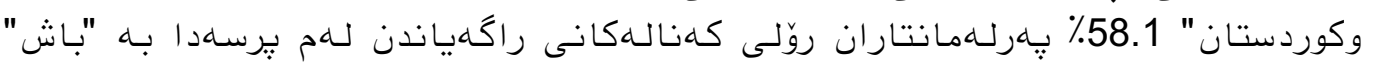

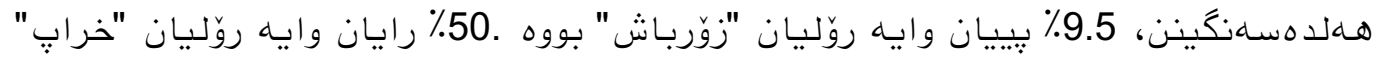

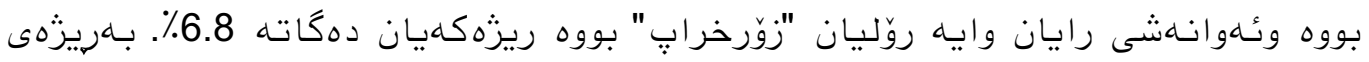

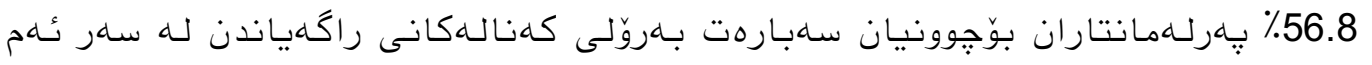

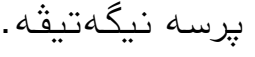

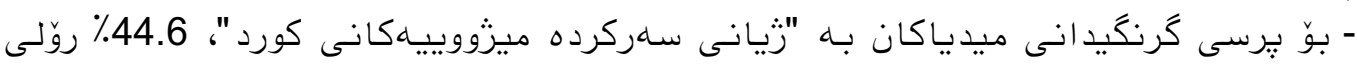

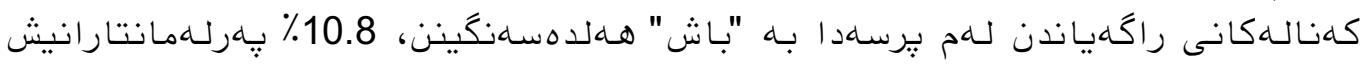

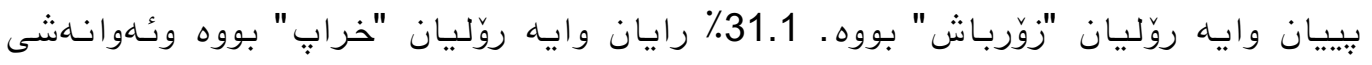




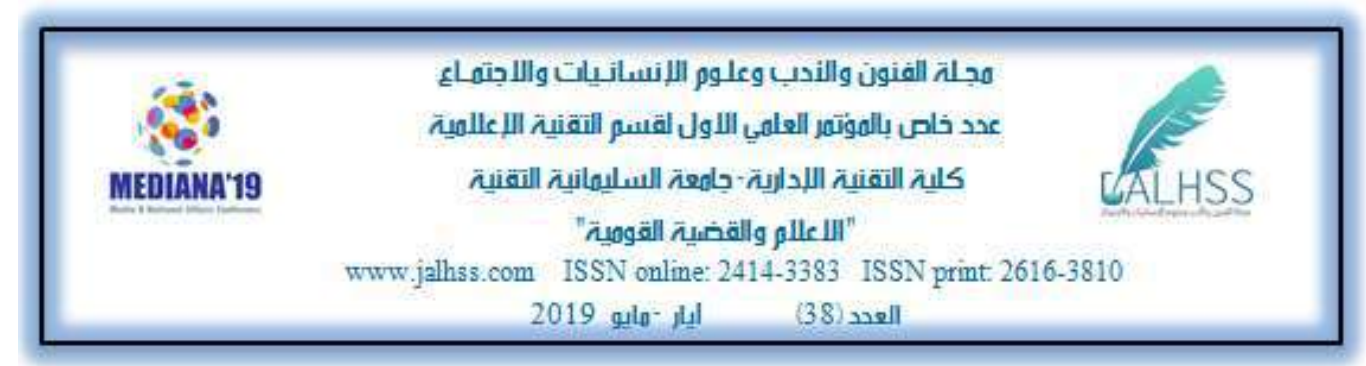

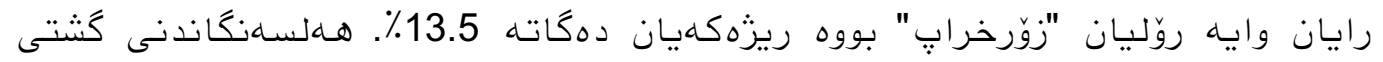

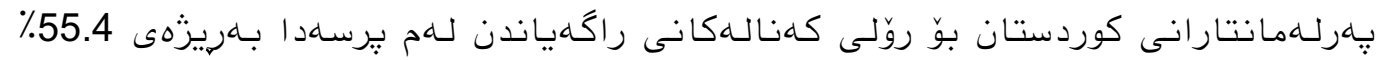

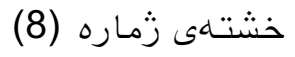

\begin{tabular}{|c|c|c|c|c|c|c|c|c|c|}
\hline \multicolumn{2}{|c|}{ زَّرخراب } & \multicolumn{2}{|c|}{ خراب } & \multicolumn{2}{|c|}{ باش } & \multicolumn{2}{|c|}{ زَّربـاش } & \multirow{2}{*}{ 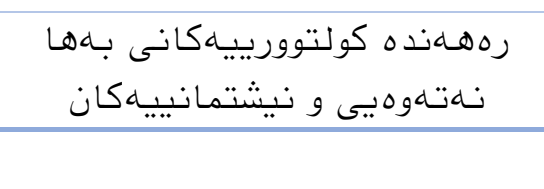 } & \multirow[t]{2}{*}{ j } \\
\hline$\%$ & ز & $\%$ & $\dot{j}$ & $\%$ & $\dot{j}$ & $\%$ & $\dot{~ j}$ & & \\
\hline 6.8 & 5 & 35.1 & 26 & 51.4 & 38 & 6.8 & 5 & پاراستنى زمان و كولتوور و داب و & 1 \\
\hline 13.5 & 10 & 54.1 & 40 & - & - & 32.4 & 24 & 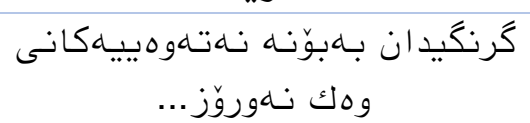 & 2 \\
\hline 12.2 & 9 & 43.2 & 32 & 36.5 & 27 & 8.1 & 6 & كرنزيد ان بـه جل و بـهركى & 3 \\
\hline 14.9 & 11 & 54.1 & 40 & 27.0 & 20 & 4.1 & 3 & هـاند ان بوّ كارى خوّبـهشَى لـه & 4 \\
\hline 13.5 & 10 & 40.5 & 30 & 37.8 & 28 & 8.1 & 6 & 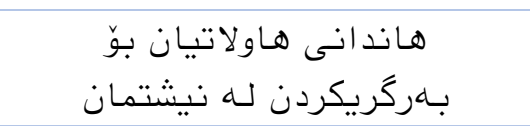 & 5 \\
\hline
\end{tabular}

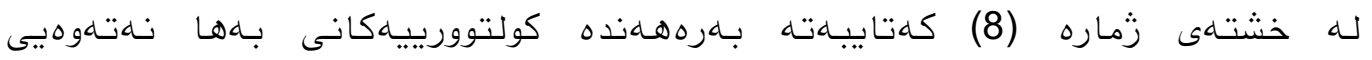

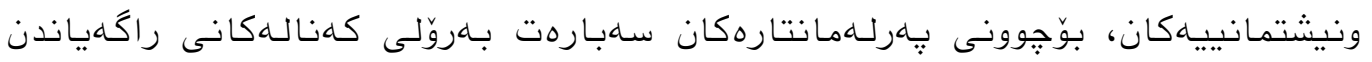
باهم شيوهيه د ابـاهشبووه:

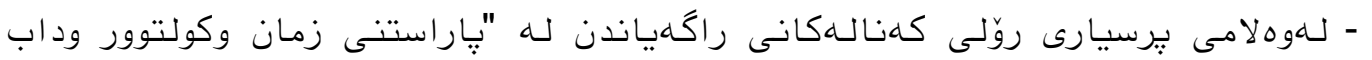

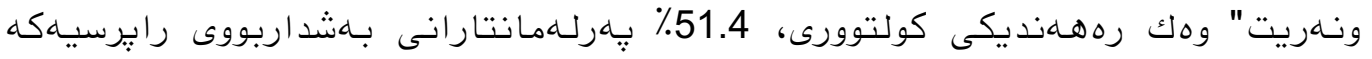

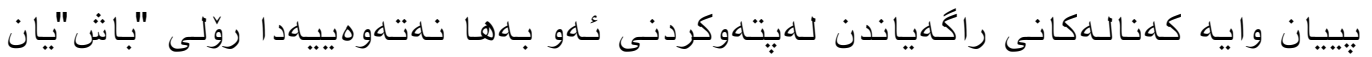

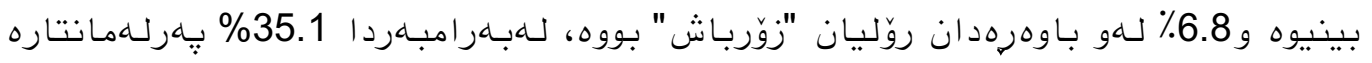

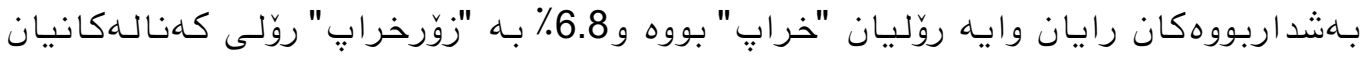

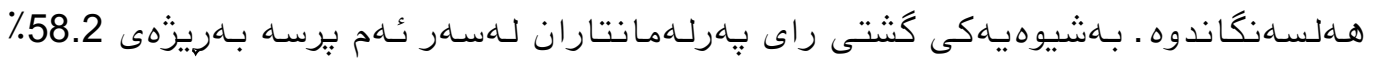

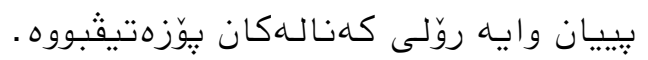

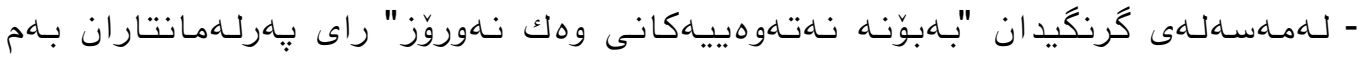

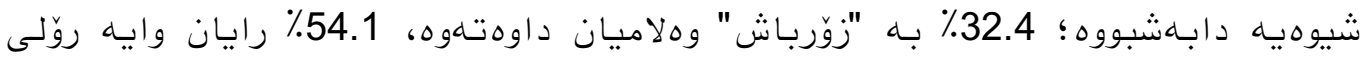

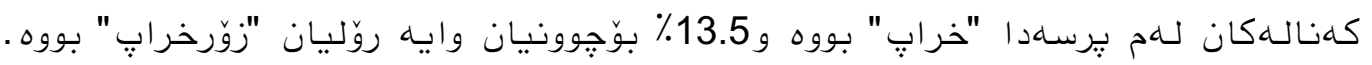




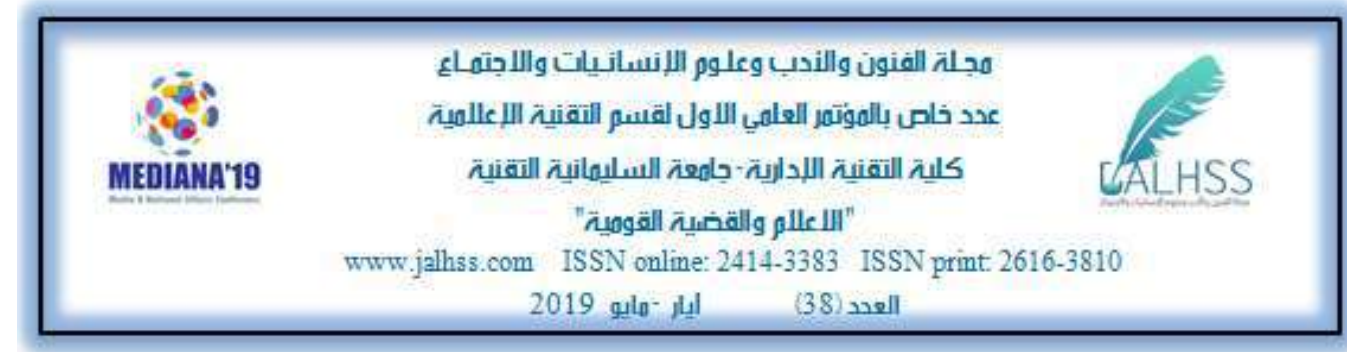

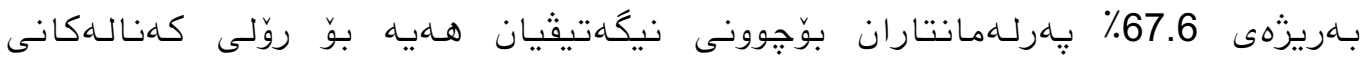

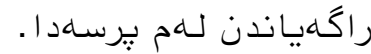

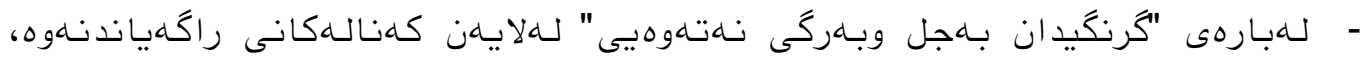

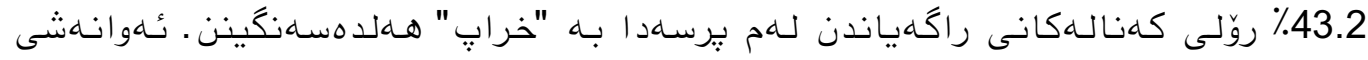

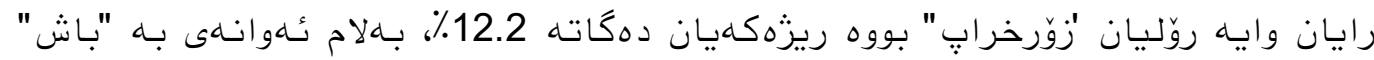

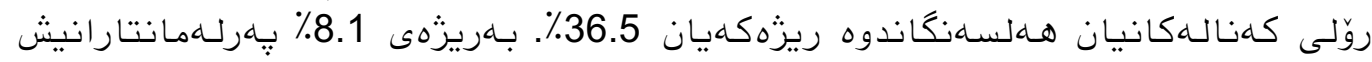

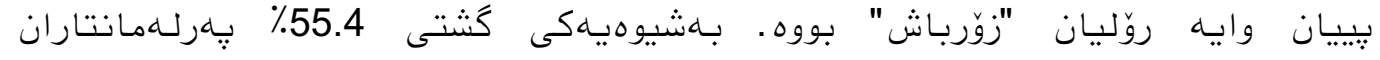

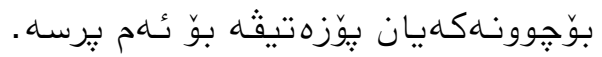

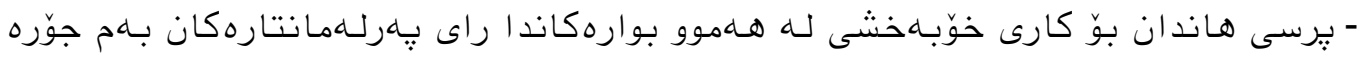

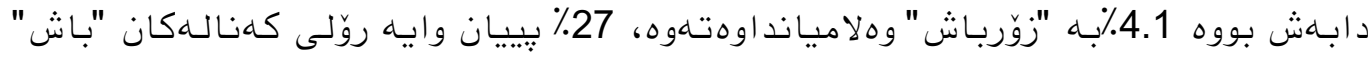

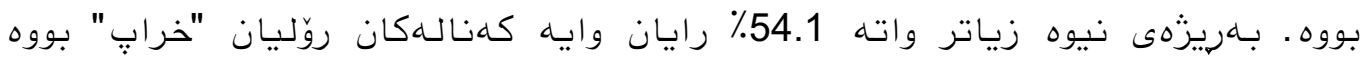

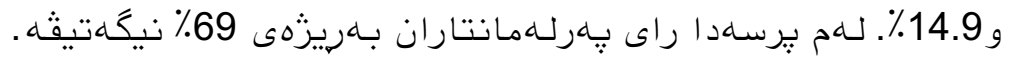

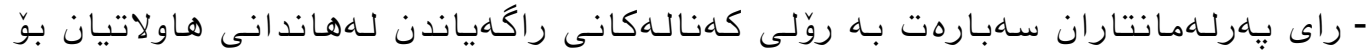

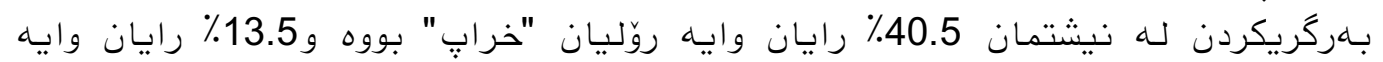

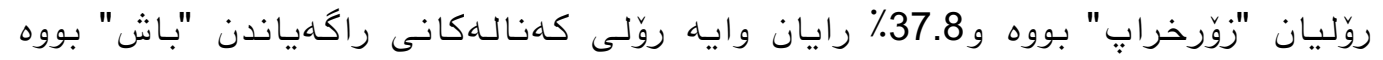

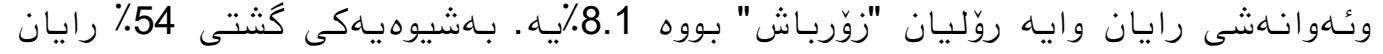

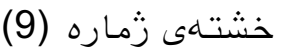

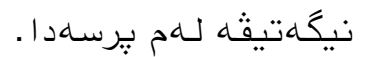

\begin{tabular}{|c|c|c|c|c|c|c|c|c|c|}
\hline \multicolumn{2}{|c|}{ 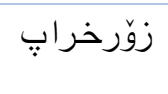 } & \multicolumn{2}{|c|}{ خراب } & \multicolumn{2}{|c|}{ باش } & \multicolumn{2}{|c|}{ 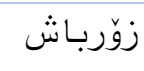 } & رههـهنده كوّمهلايهت يبيهـكانى بههـا & j \\
\hline$\%$ & $\dot{j}$ & $\%$ & $\dot{j}$ & $\%$ & $\dot{j}$ & $\%$ & $\dot{j}$ & & \\
\hline 5.4 & 4 & 37.8 & 28 & 47.3 & 35 & 9.5 & 7 & يتهوكردني بيكهوهزيـان & 1 \\
\hline 9.5 & 7 & 45.9 & 34 & 39.2 & 29 & 5.4 & 4 & 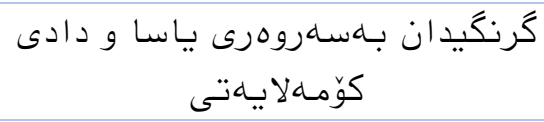 & 2 \\
\hline
\end{tabular}

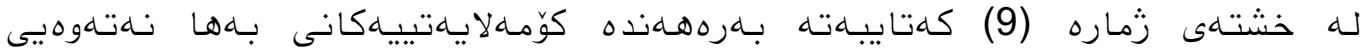

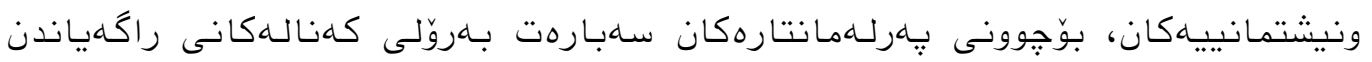

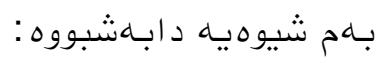

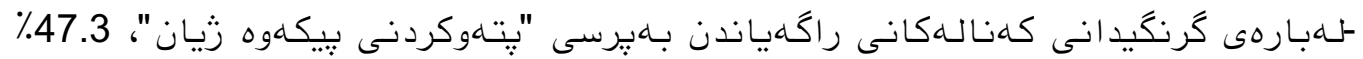

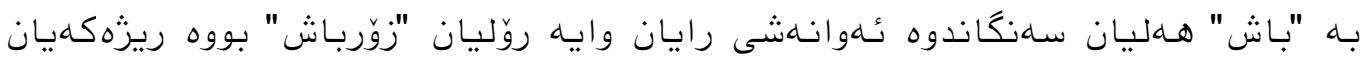




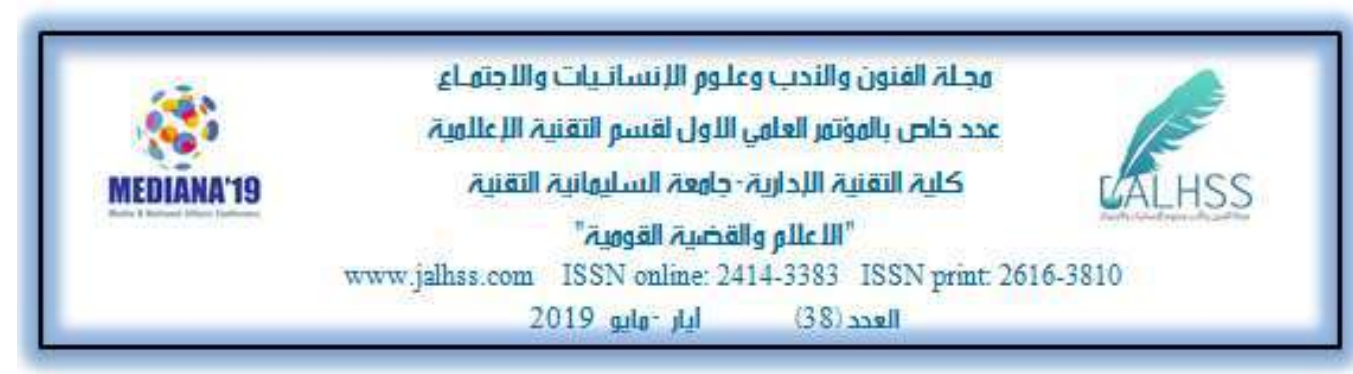

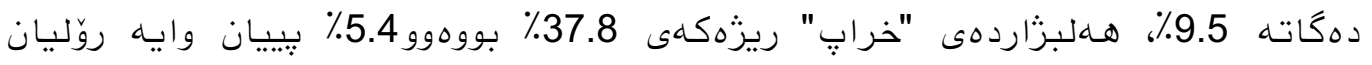

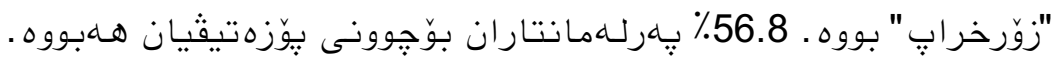

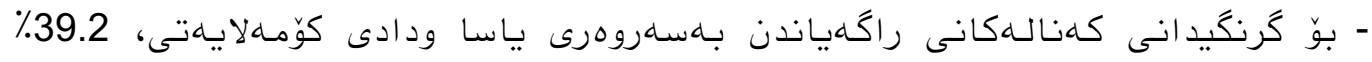

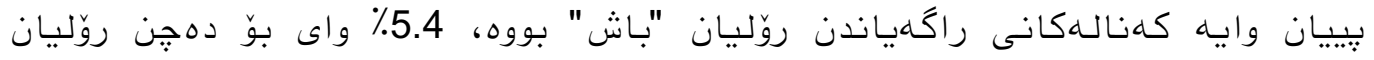

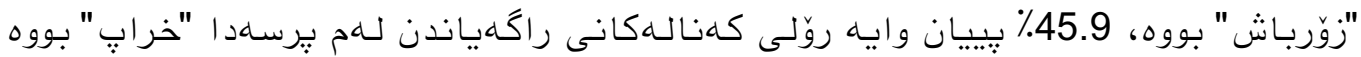

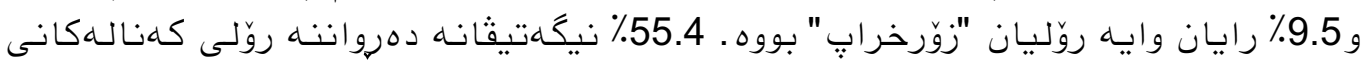

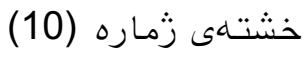

\begin{tabular}{|c|c|c|c|c|c|c|c|c|c|}
\hline \multicolumn{2}{|c|}{ زوَرخراب } & \multicolumn{2}{|c|}{ خراب } & \multicolumn{2}{|c|}{ بـاش } & \multicolumn{2}{|c|}{ ز تَّربـاش } & \multirow{2}{*}{ 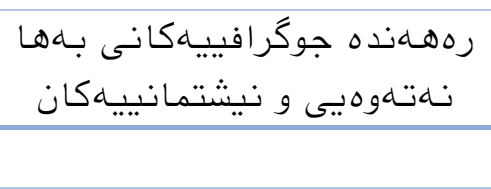 } & \multirow[t]{2}{*}{ j } \\
\hline$\%$ & $\dot{j}$ & $\%$ & $\dot{j}$ & $\%$ & $\ddot{j}$ & $\%$ & J & & \\
\hline 14.9 & 11 & 43.2 & 32 & 36.5 & 27 & 5.4 & 4 & كرنزيد ان بـه كَهرانهوهى ناوجهه & 1 \\
\hline 16.2 & 12 & 44.6 & 33 & 31.1 & 23 & 8.1 & 6 & خوّشاهويستى خاك و نيشتمـان & 2 \\
\hline 13.5 & 10 & 47.3 & 35 & 33.8 & 25 & 5.4 & 4 & پاراستنى زينگگهى كوردستان & 3 \\
\hline
\end{tabular}

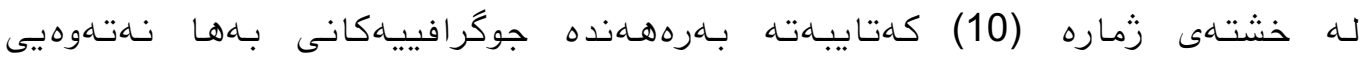

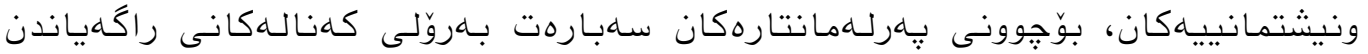

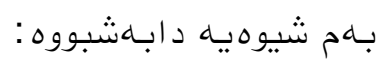

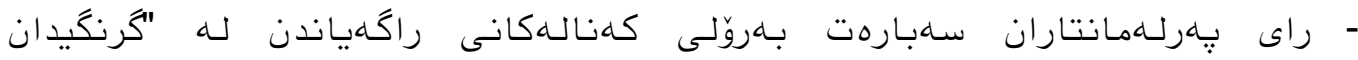

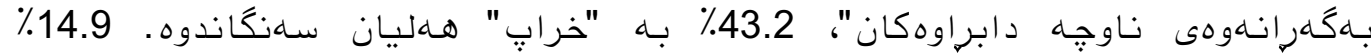

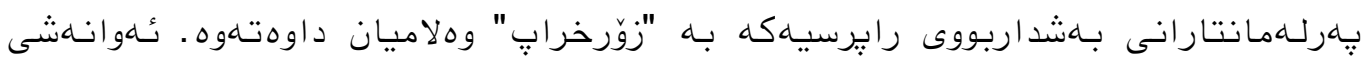

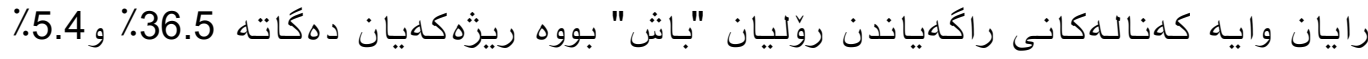

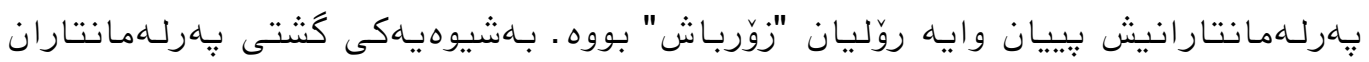

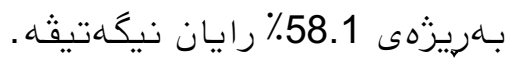

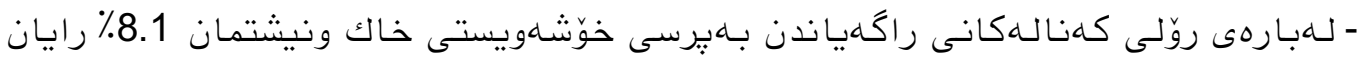

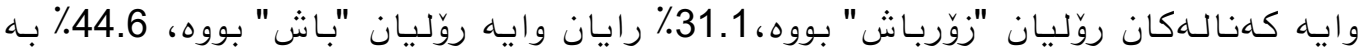

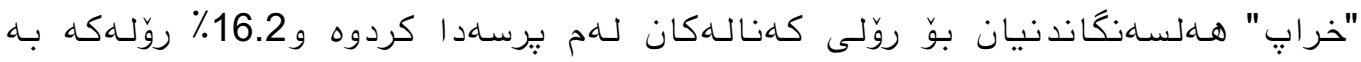

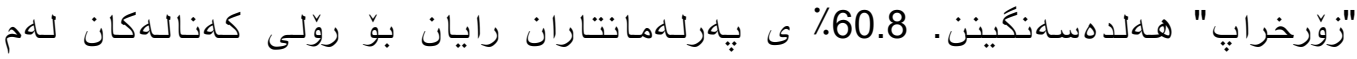
برسهدا نيكَهتيفه. 


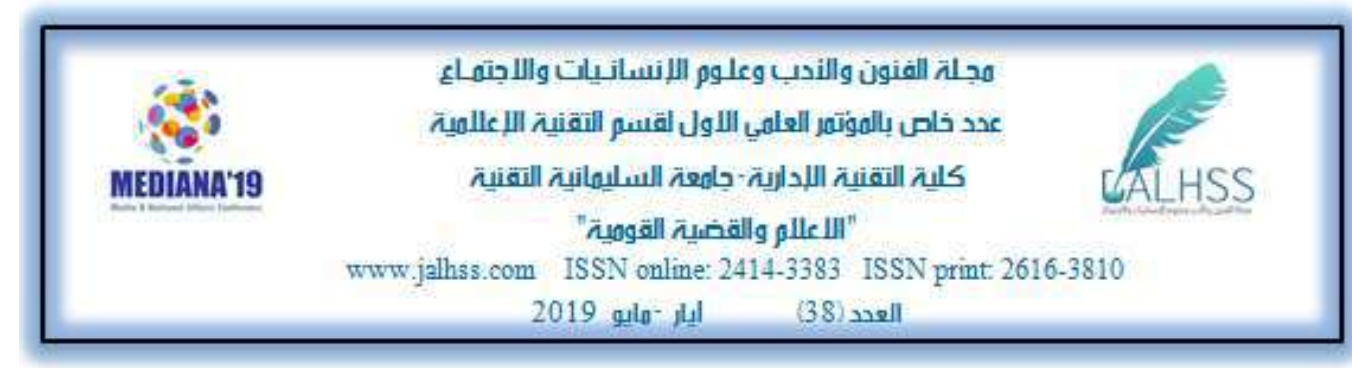

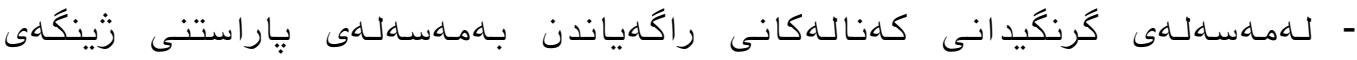

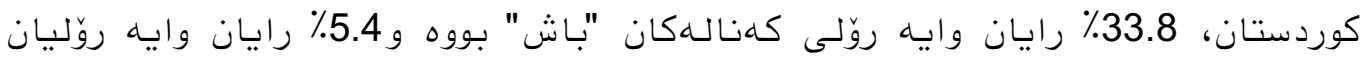

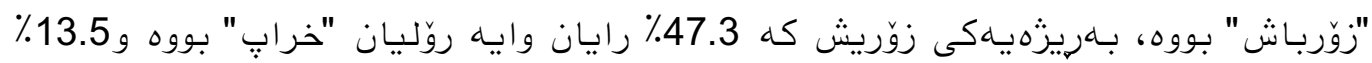

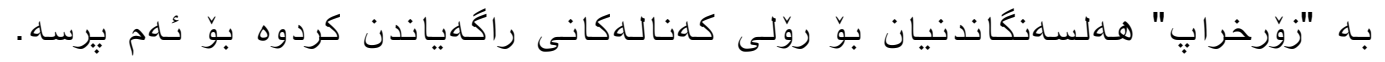

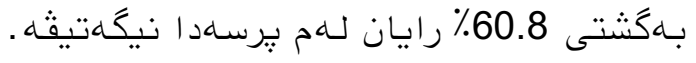

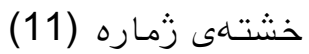

\begin{tabular}{|c|c|c|c|c|c|c|c|c|c|}
\hline \multicolumn{2}{|c|}{ زَّرخراب } & \multicolumn{2}{|c|}{ خراب } & \multicolumn{2}{|c|}{ باش } & \multicolumn{2}{|c|}{ 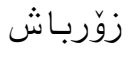 } & رههـلنده ئابورى بـهـا نـهتهوهيى و & j \\
\hline$\%$ & $\dot{j}$ & $\%$ & $\dot{j}$ & $\%$ & j & $\%$ & $\dot{j}$ & & \\
\hline 8.1 & 6 & 64.9 & 48 & 20.3 & 15 & 6.8 & 5 & 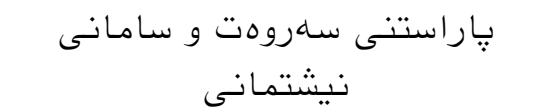 & 1 \\
\hline 6.8 & 5 & 43.2 & 32 & 40.5 & 30 & 9.5 & 7 & 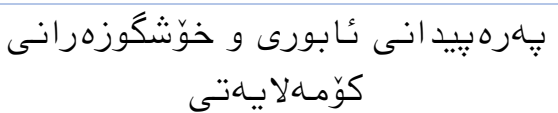 & 2 \\
\hline
\end{tabular}

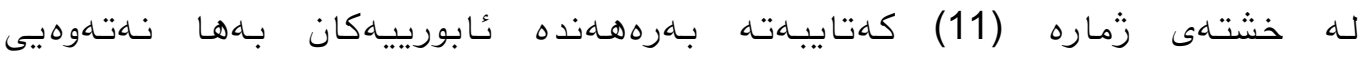

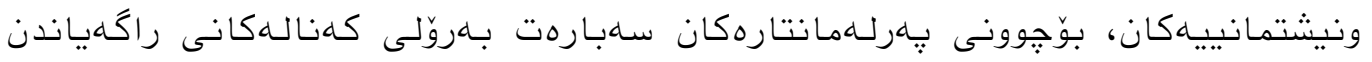

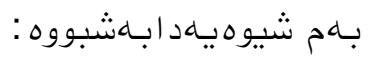

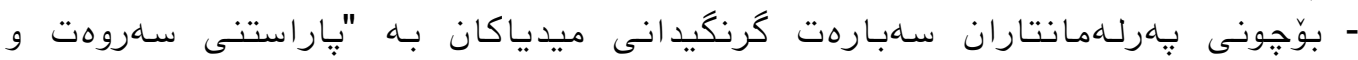

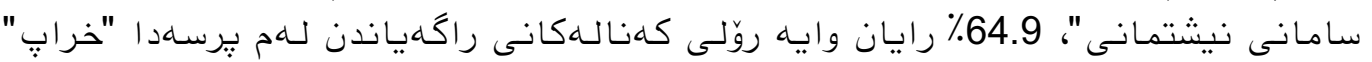

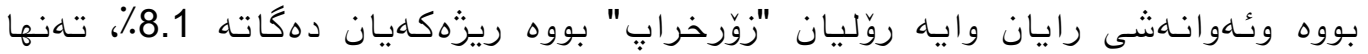

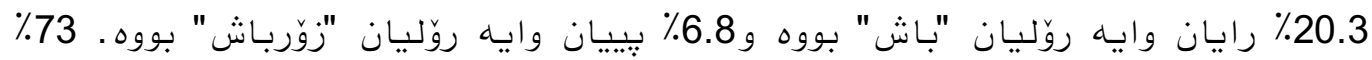

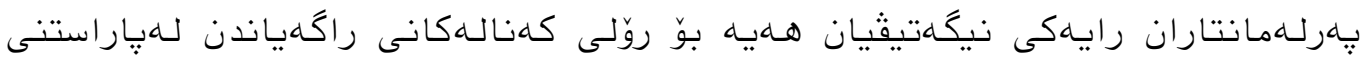

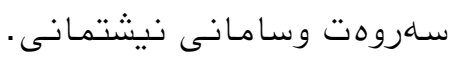

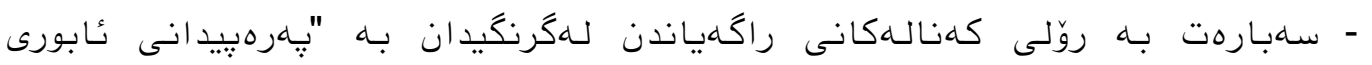

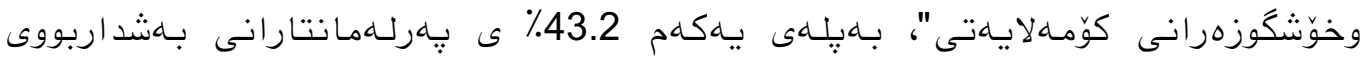

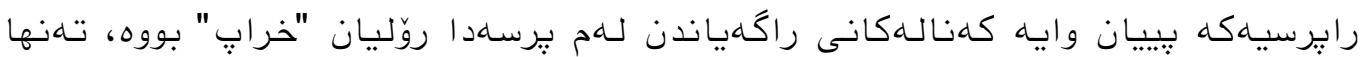

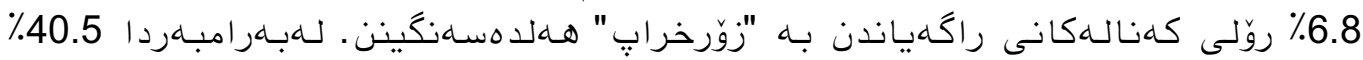

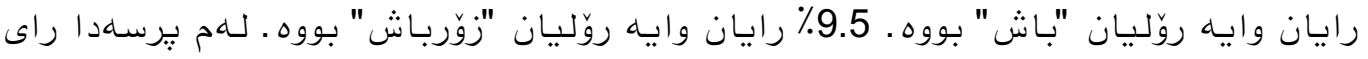

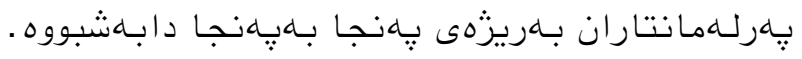




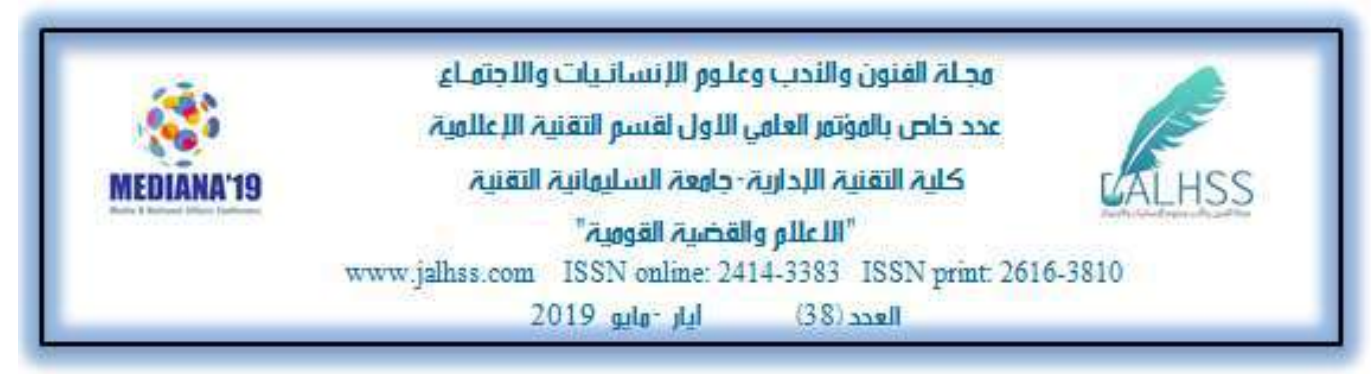

دووهم • دهرئهنجامى تاقيكردنـهوهى كريمانهكان:

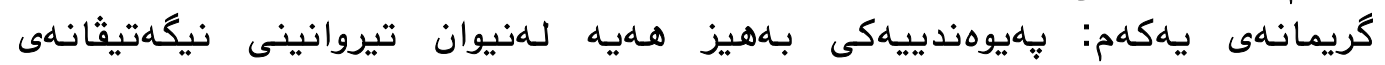

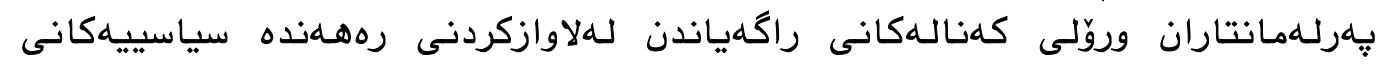

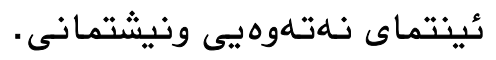

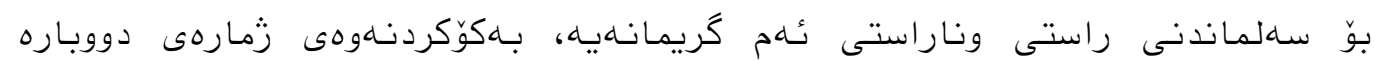

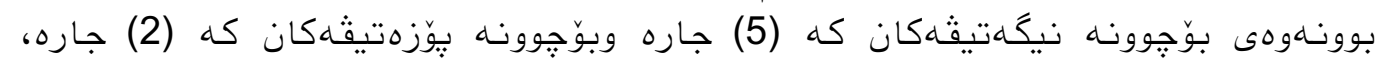

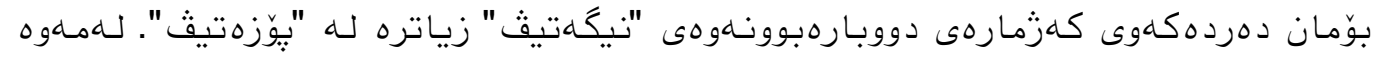

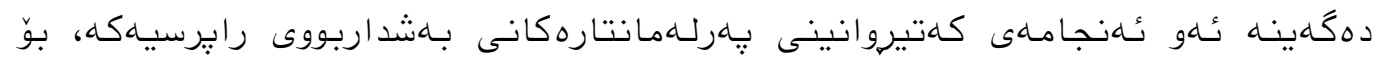

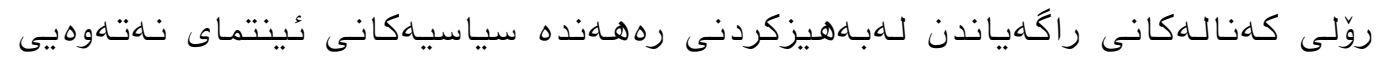

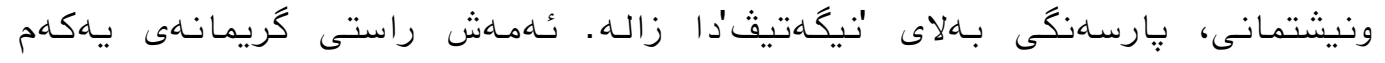

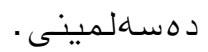

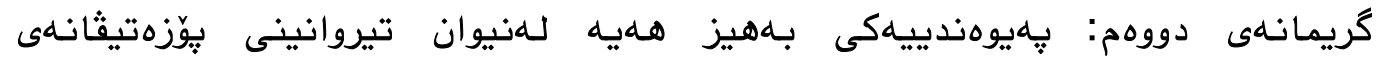

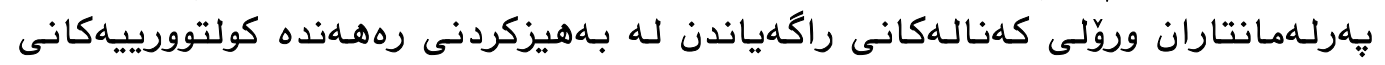

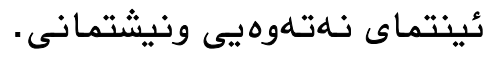

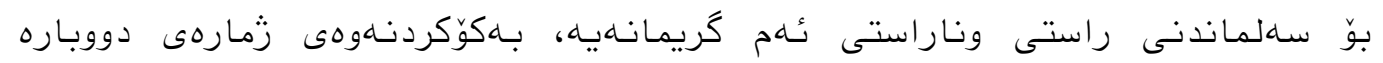

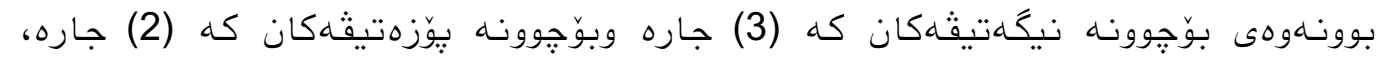

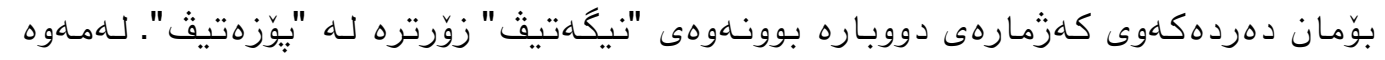

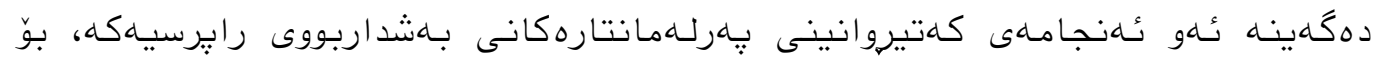

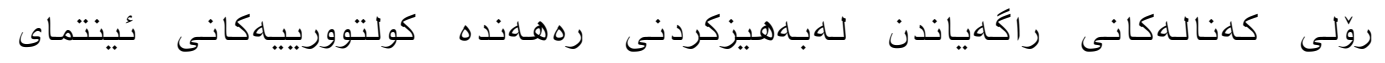

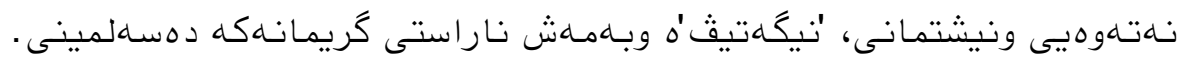

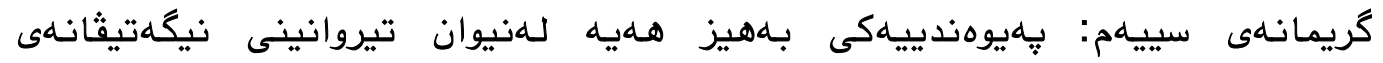

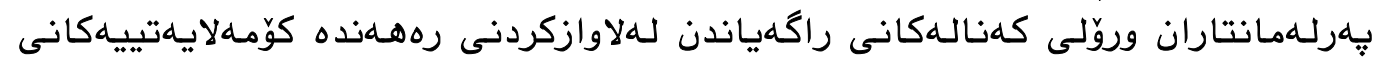

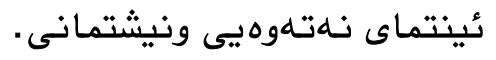

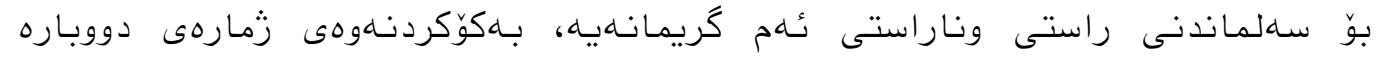

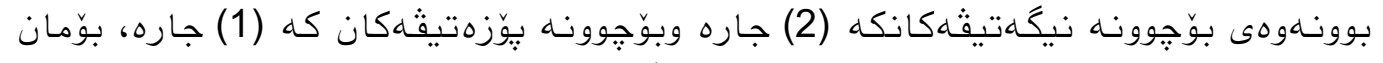

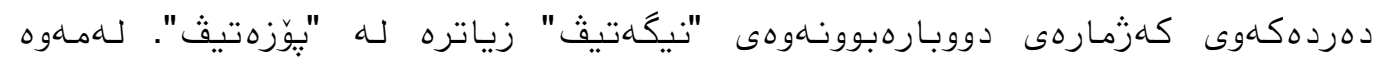

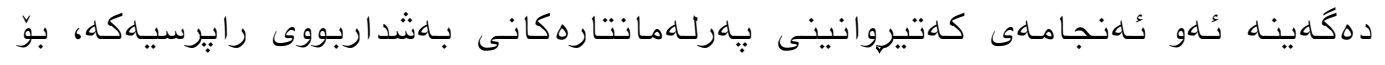

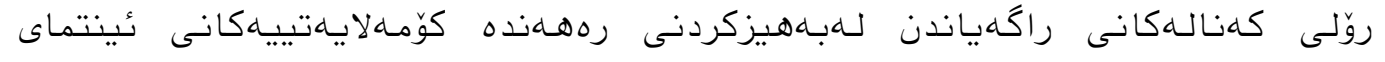

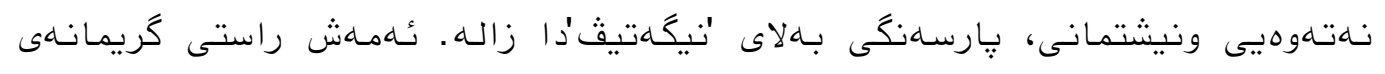

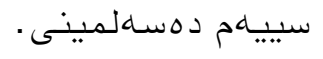




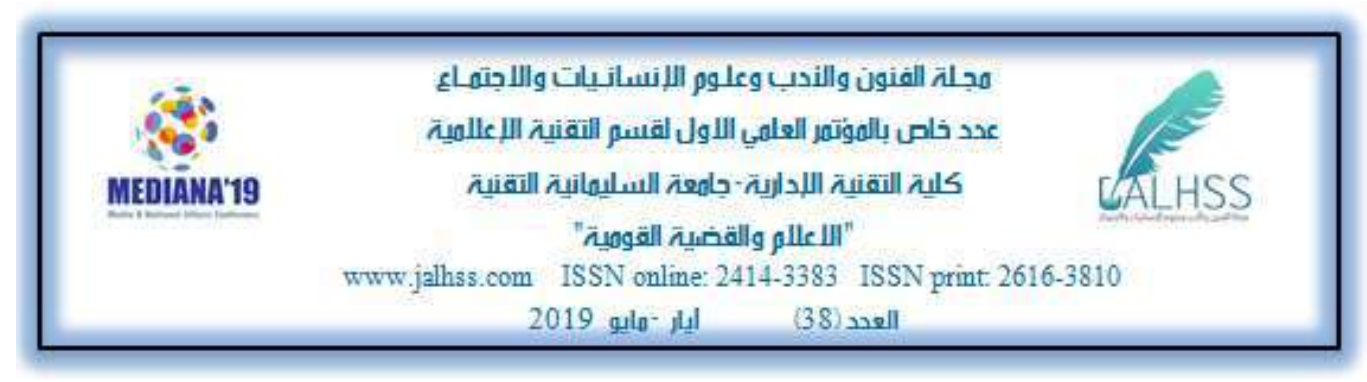

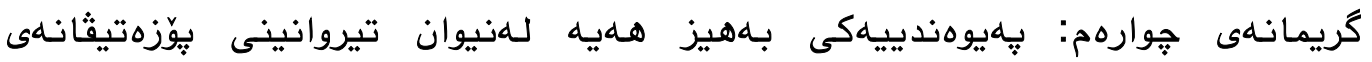

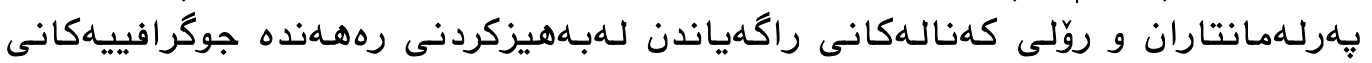

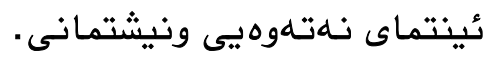

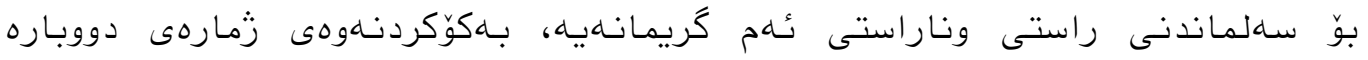

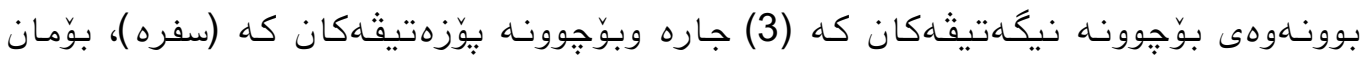

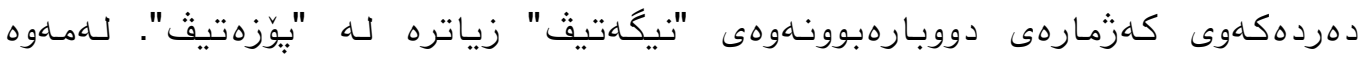

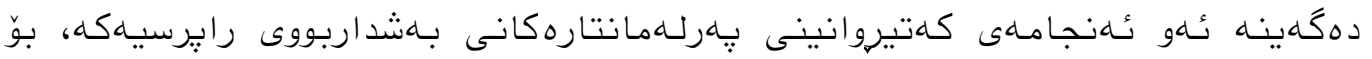

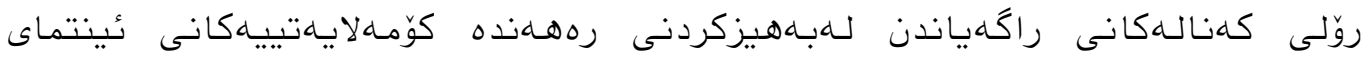

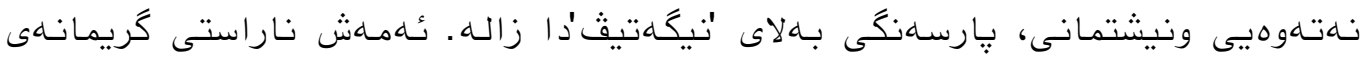

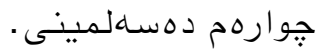

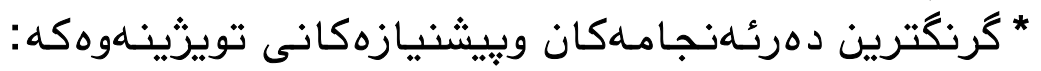

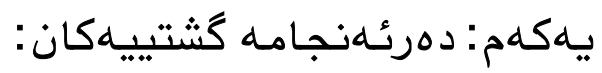

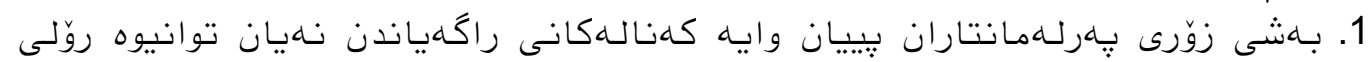

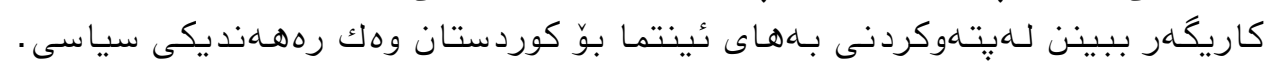

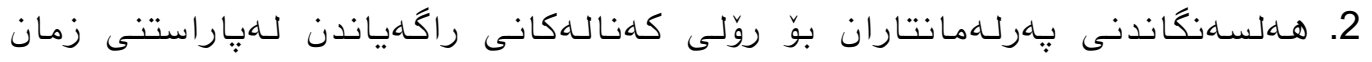

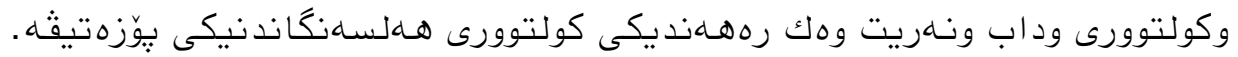

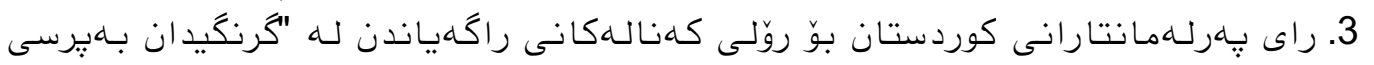

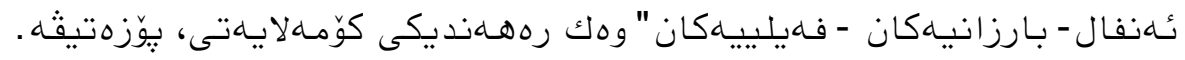

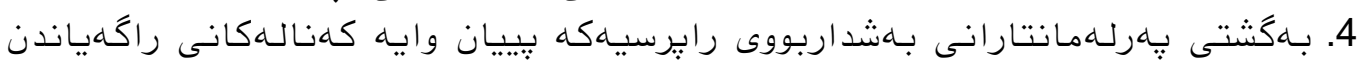

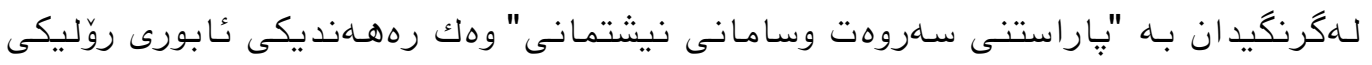

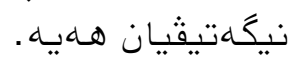

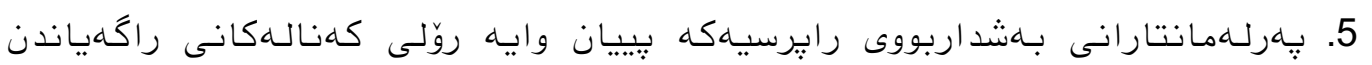

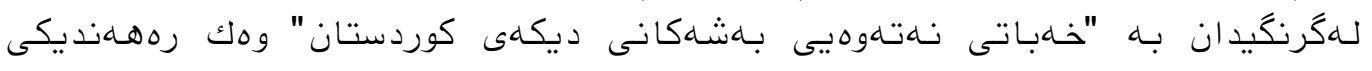

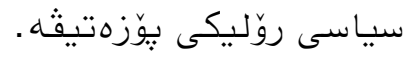

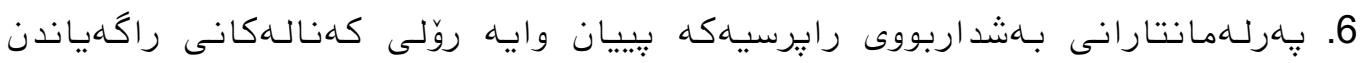

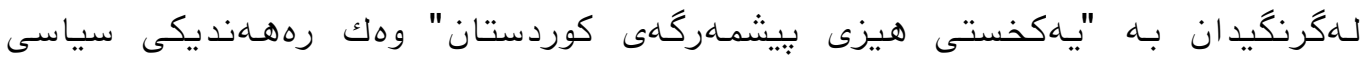
روّليكى نيكَهتيقبُووه

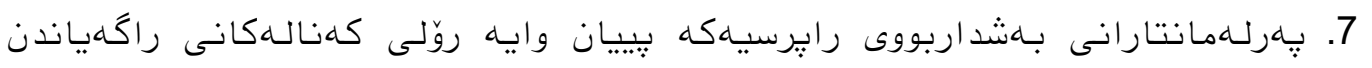

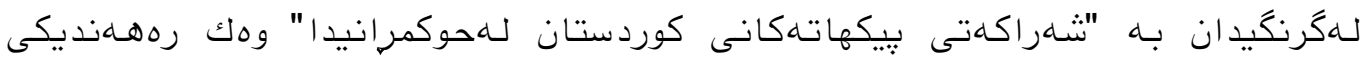

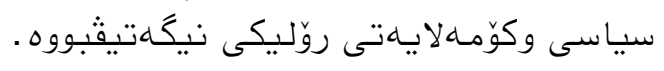




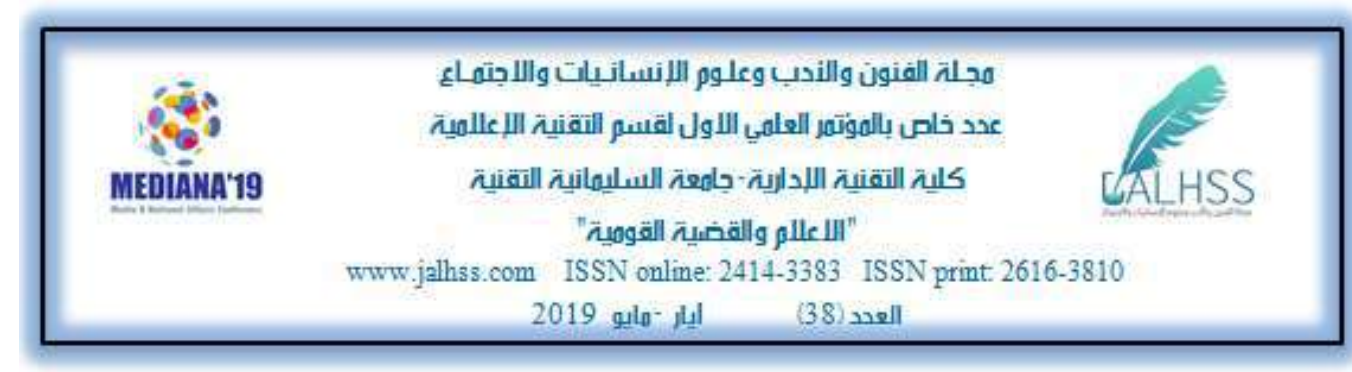

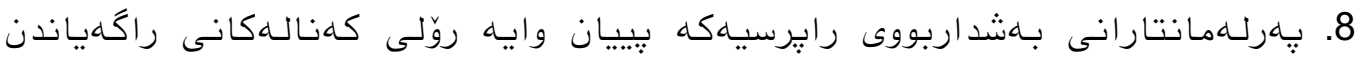

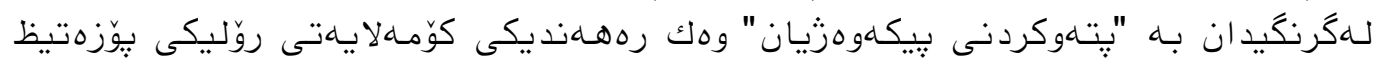
بووه.

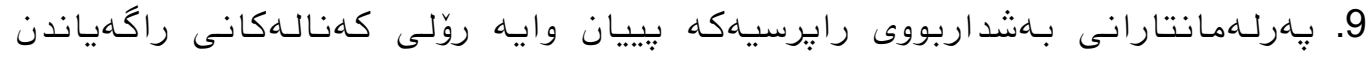

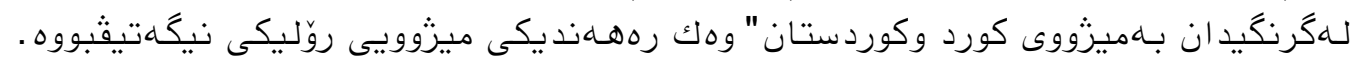

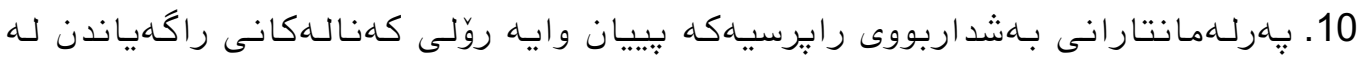

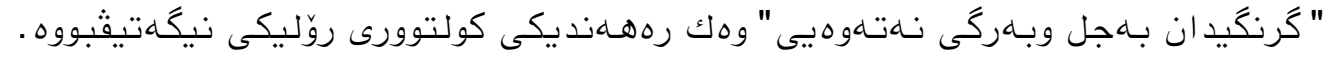

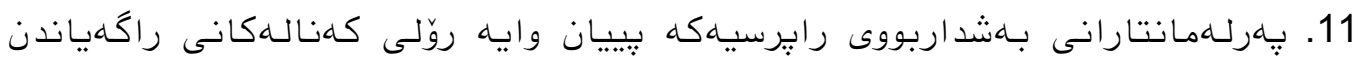

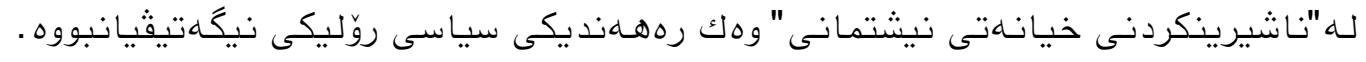

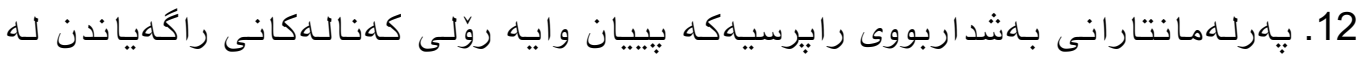

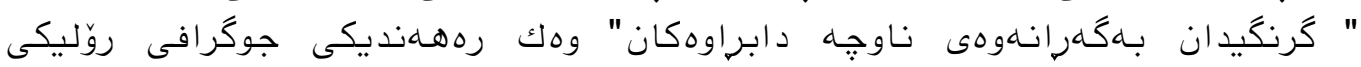
نيكُهتيقيانبووه.

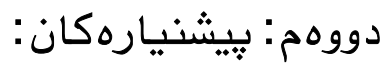

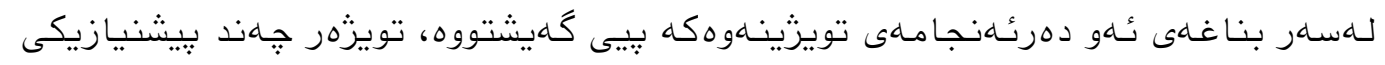
خستووهتتهووو كهبريتين له:

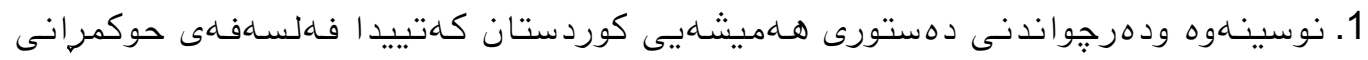

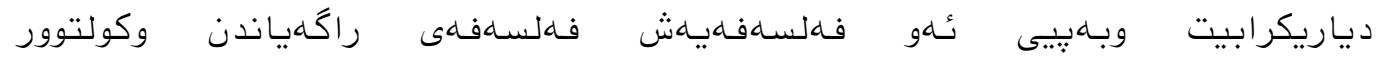

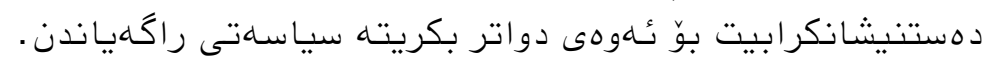

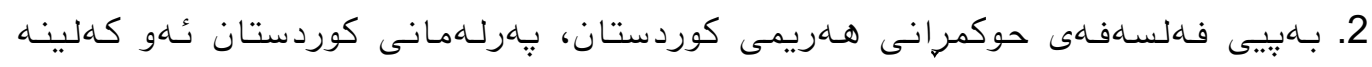

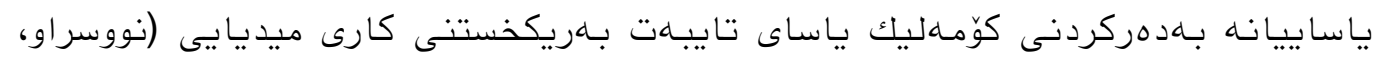

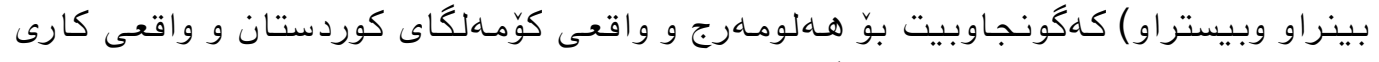

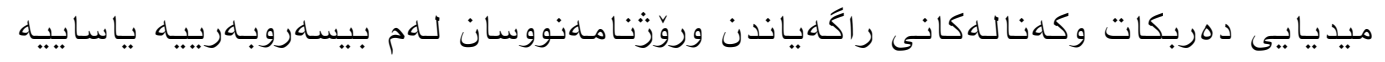
رزكار بكات.

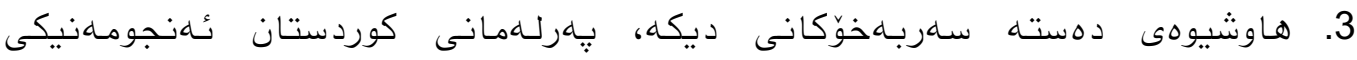

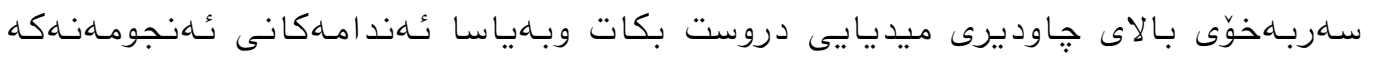

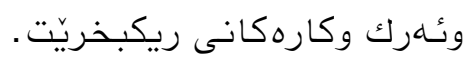

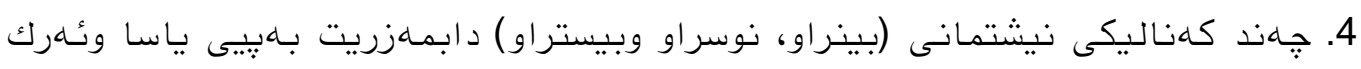
وكارهكانيان ريكبخريّت 5.

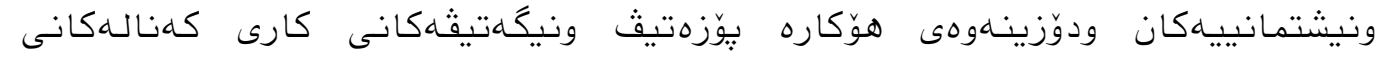

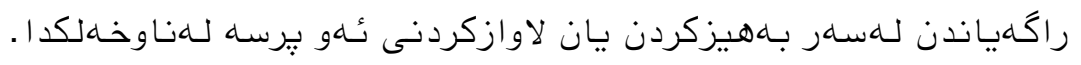




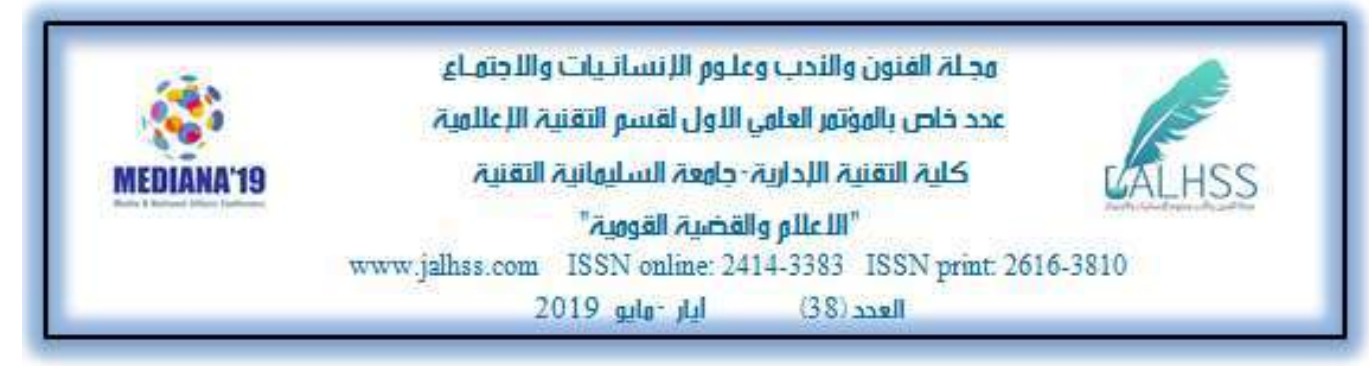

$$
\text { * سهرجهاوهاوكان: }
$$

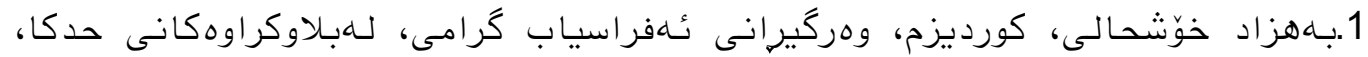

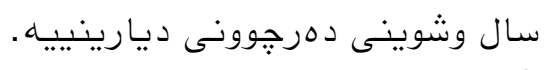

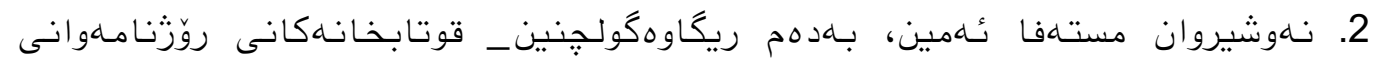

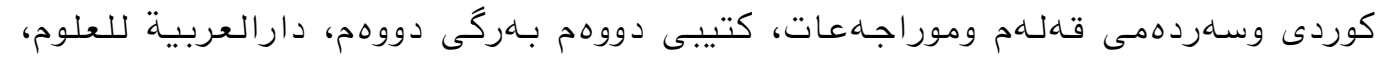

$$
\text { بيروت_ لبنان } 2013 .
$$

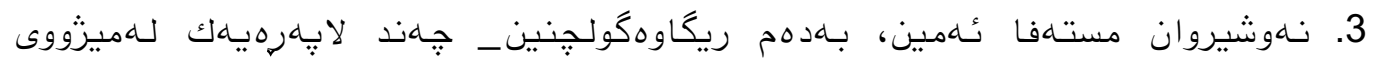

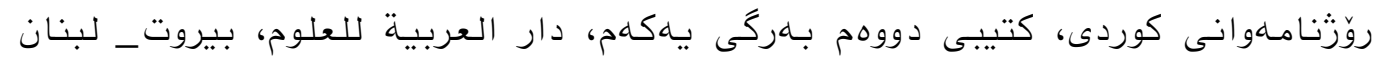

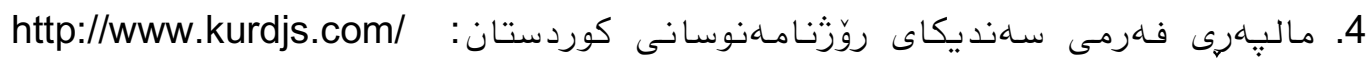

kurdish/data

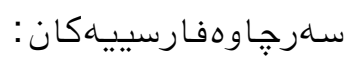

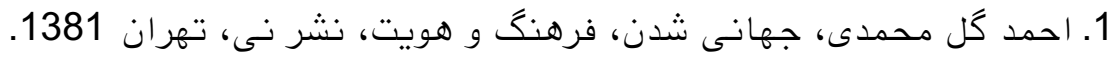

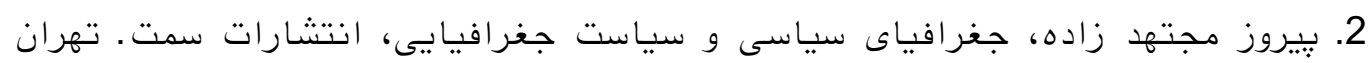

3. جين اريك لين، سوانته ارسون، فرهنگ و سياست، برثوهشكده ى مطالعات فرهنگى و

$$
\text { اجتماعى، تهران، }
$$

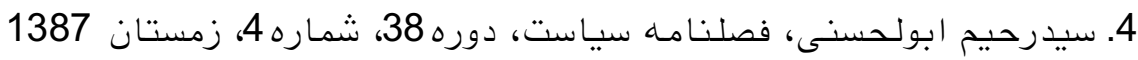

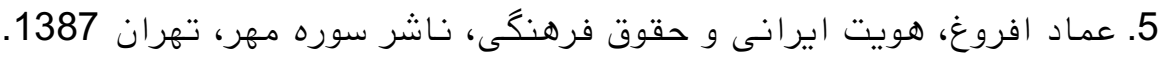

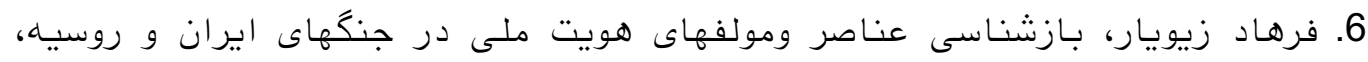

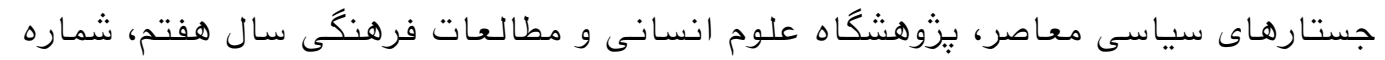
دوم، تابستان 1395.

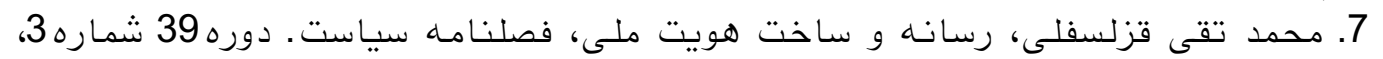

$$
\text { سا تاريز 1388. }
$$

1. مفتاح بن هدية، القيم الوطنية في المنهائه التهاج التعليمية، الجزائر، جامعة محمد لمين دباغين، أطروحة دكتوراة، 2018.

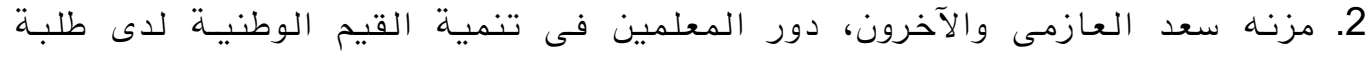

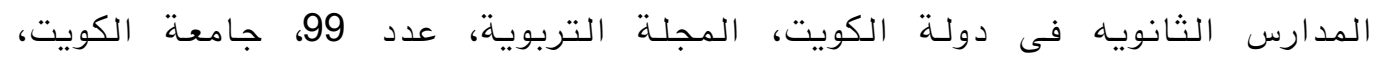
يونيو 2011. 


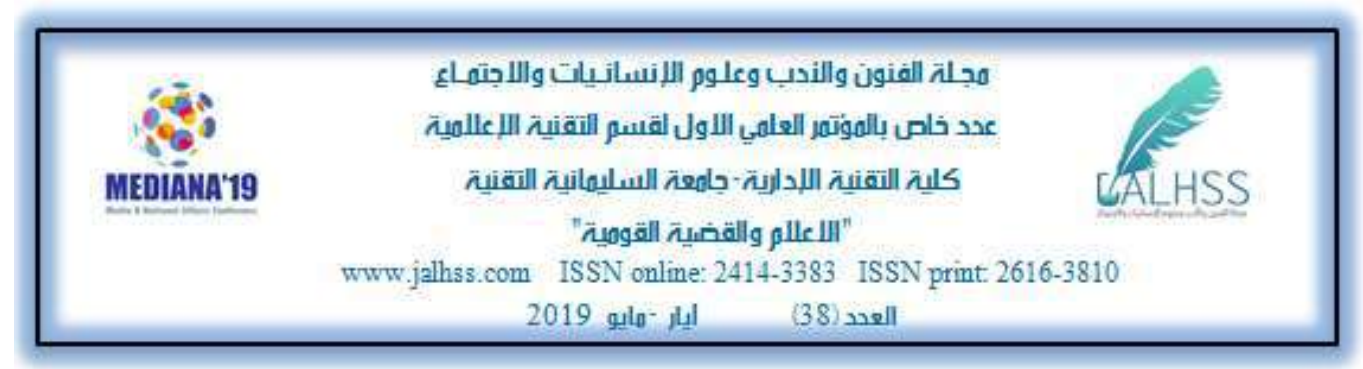

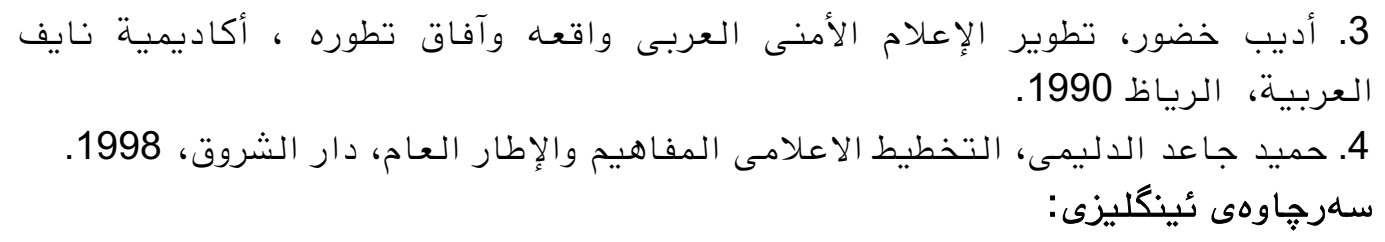
1.AndrewThompson, (2001); "National Identity and Human Agency", The sociologicalReview, Vol. 49, No. 1. 